

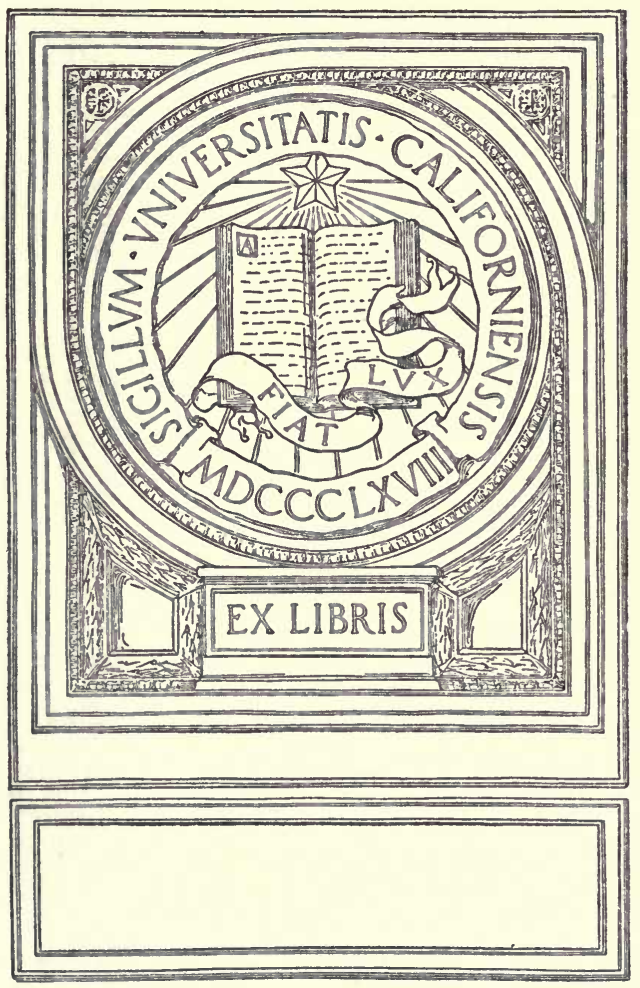







\section{3ọ Dallas Lare \$barp}

THE BETTER COUNTRY.

THE MAGICAL CHANCE.

EDUCATION IN A DEMOCRACY.

THE SEER OF SLABSIDES.

ROOF AND MEADOW.

THE HILLS OF HINGHAM.

WHERE ROLLS THE OREGON.

THE FACE OF THE FIELDS.

THE LAY OF THE LAND.

NATURE SERIES.

BOOK I. THE FALL OF THE YEAR.

BOOK II. WINTER.

BOOK III. THE SPRING OF THE YEAR.

BOOK IV. SUMMER.

THE YEAR OUT OF DOORS.

WAYS OF THE WOODS.

HOUGHTON MIFFLIN COMPANY

Boston AND New YoRK 


\section{WHERE ROLLS THE OREGON}




\title{
WHERE ROLLS THE OREGON
}

\author{
BY \\ DALLAS LORE SHARP
}

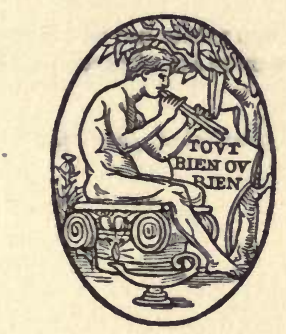

\author{
BOSTON AND NEW YORK \\ HOUGHTON MIFFLIN COMPANY \\ che thibrtioe prest Cambrioge
}


COPYRIGHT, I913 AND I9I4, BY THE ATLANTIC MONTHLY COMPANY COPYRIGHT, I9I4, BY THE GOLDEN RULE COMPANY

COPYRIGHT, 1914, BY THE CENTURY COMPANY

COPYRIGHT, 19I4, BY DALLAS LORE SHARP

ALL RIGHTS RESERVED INCLUDING THE RIGHT TO REPRODUCR

THIS BOOK OR PARTS THEREOF IN ANY FORM

Published June ror4

BIOLOGY

LIBRARY 


\title{
QH81 \\ 5514 \\ BIOLOGY \\ LIBRARY
}

\author{
To MY FRIENDS \\ WILLIAM L. FINLEY \\ STATE GAME WARDEN OF OREGON \\ AND \\ HERMAN T. BOHLMAN \\ LOVER AND PHOTOGRAPHER \\ OF WILD LIFE
}





\section{CONTENTS}

I. THREE-ARCH ROCKS RESERVATION - I

II. THE RAVEN OF THE DESCHUTES • $\quad 27$

III. FROM BEND TO BURNS • • $\quad 45$

IV. THE SHADOW OF THE DESERT . . 69

V. ON THE MARSHES OF MALHEUR - 93

VI. THE SPIRIT OF THE HERD . • . II7

VII. THE BUTTERFLIES OF MOUNT HOOD 145

VIII. THE ROCKS FOR THE CONIES • • I7I

IX. MOTHER CAREY'S CHICKENS • • . I9I

X. THE WILD MOTHER • • . . $21 x$

XI. MOUNT HOOD FROM COUNCIL CREST . 237

INDEX • • • • • • $\quad 247$ 


\section{PREFACE}

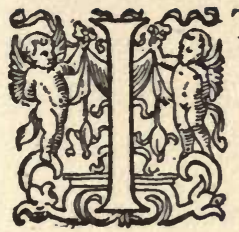

T was not to write a book that I visited the Northwest. One need not go so far from Massachusetts to do that. The apple trees under Mullein Hill are as full of books as

... the continuous woods

Where rolls the Oregon.

I spent the summer of 1912 in Oregon, studying the wild life of the State, the fish and game, and particularly the work of the Game Warden in its educational aspects. I took no pencil with me for fear I might write out my eyes. And Nature hates an interviewer anyway. So this volume is not a series of notes, but a group of impressions, deep, indelible impressions of the vast outdoors of Oregon.

"Vast" is the right word for Oregon, vast and varied, - the most alluring land to the naturalist within the compass of our coasts. From ThreeArch Rocks in the Pacific to the broad backs of the Steins we travelled; from the peaks of the 
Wallowas to the tule marshes of Klamath Lake Reservation - a summer far greater than the pages of this book. For I have not spoken of the firs of the Coast Range, nor of the pines of the Cascades, nor of the orchards of the river valleys, nor of the salmon of the Columbia, nor of a hundred other things that together give character and personality to the State. Nor have I spoken of the hospitality of the people; space would fail me, for it is the largest thing in the State.

But here I must thank Mr. William Lovell Finley, the State Game Warden, to whom I owe my summer in Oregon; and here express my keen appreciation of the great work he is doing. To his friend, and my friend, Herman T. Bohlman, I am also deeply indebted; as well as to the deputy wardens who were extraordinarily kind and helpful to me.

Oregon, and the country as a whole, owe Finley and Bohlman a large debt for what they have done to preserve wild life. It was largely due to their efforts that the great Federal reservations of Oregon were set aside.

I wish to thank them and Mr. George $\mathbf{M}$ 


\section{PREFACE}

Weister of Portland, for the use of their splendid photographs as illustrations for this book. My thanks are due also to the Editors of the Atlantic Montbly, Country Life in America, and St.Nicbolas for privilege to reprint the chapters that appeared first in their magazines.

Dallas Lore Sharp.

Mullein Hill, May, 1914. 



\section{WHERE ROLLS THE OREGON \\ I}

THREE-ARCH ROCK RESERVATION 



\title{
WHERE ROLLS THE OREGON
}

\author{
I
}

THREE-ARCH ROCKS RESERVATION

I

HE fog was lifting. The thick, wet

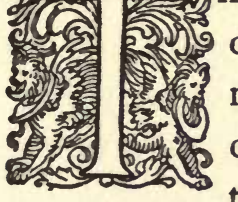
drift that had threatened us on Tillamook Bar stood clear of the shouldering sea to the westward, and in toward shore, like an upper sea, hung at the fir-girt middles of the mountains, as level and as gray as the sea below. There was now no breeze. The long, smooth swell of the Pacific swung under us and in, until it whitened at the base of three dark rocks that lay in our course, and which now began to take on form out of the foggy distance. Gulls were flying over us; lines of black cormorants and crowds of murres were winging past toward the rocks; but we were still 


\section{WHERE ROLLS THE OREGON}

too far away from the looming piles to see that the gray of their walls was the gray of uncounted colonies of nesting birds, colonies that covered the craggy steeps as the green firs clothed the slopes of the Coast Range mountains, up to the hanging fog.

As we steamed on nearer, the sound of the surf about the rocks became audible; the birds in the air grew more numerous, their cries now faintly mingling with the sound of the sea. The hole in the Middle Rock, a mere fleck of foam at first, widened rapidly into an arching tunnel through which our boat might have run; the sea began to break before us over half-sunken ledges; and soon upon us fell the damp shadows of Three-Arch Rocks, for now we were looking far up at their sides, at the sea-birds in their guano-gray rookeries, - gulls, cormorants, guillemots, puffins, murres, - encrusting the ragged walls from tide-line to pinnacle, as the crowding barnacles encrusted the bases from the tide-line down.

We were not approaching without protest, for the birds were coming off to meet us, more and more the nearer we drew, wheeling and clacking overhead in a constantly thickening cloud of low- 


\section{THREE-ARCH ROCKS}

ering wings and tongues. We rounded the outer, Shag Rock, and headed slowly in toward the yawning hole of Middle Rock as into some mighty cave, so sheer and shadowy rose the walls above us, so like to cavern thunder was the throbbing of the surf through the hollow arches, was the flapping and screaming of the birds against the highcircling walls, was the deep menacing grumble of the lions, as through the muffle of surf and sea-fowl, herd after herd lumbered bellowing into the foam.

It was a strange, wild scene. Hardly a mile from the Oregon coast, but cut off by breaker and bar from the abrupt, uninhabited shore, the three rocks of the Reservation, each pierced with its resounding arch, heaved their heavy shoulders from the waves straight up, huge, towering, till our little steamer coasted their dripping sides like some puffing pigmy. They were sea rocks, of no part or lot with the dry land, their beryl basins wave-scooped, and set with purple starfish, with green and pink anemones, and beaded many deep with mussels of amethyst and jet, aglitter in the water's overflow; and just above the jeweled basins, like fabled beasts of old, lay 


\section{WHERE ROLLS THE OREGON}

the sea-lions, lumpish, uncouth forms, flippered, reversed in shape, with throats like the caves of Eolus, hollow, hoarse, discordant ; and higher up, on every jutting bench and shelf, in every weathered rift, over every jog of the ragged cliffs, to their bladed backs and pointed peaks, swarmed the sea-birds, web-footed, amphibious, wave-shaped, with stormy voices given them by the winds that sweep in from the sea. And their numbers were the numbers of the sea.

Crude, crowded, weltering, such life could never have been brought forth and nurtured by the dry land; her breasts had withered at the birth. Only the bowels of the wide, wet sea could breed these heaps, these cones of life that rose volcanic from the waves, their craters clouded by the smoke of wings, their belted bases rumbling with a multi-throated thunder. The air was dank with the must of a closed room, - closed for an æon past, - no breath of the land, no odor of herb, no scent of fresh soil; but the raw, rank smells of rookery and den, saline, kelpy, fetid; the stench of fish and bedded guano; and pools of reeking ammonia where the lion herds lay sleeping on the lower rocks in the sun. 
A boat's keel was beneath me, but as I stood out on the pointed prow, barely above the water, and found myself thrust forward without will or effort among the crags and caverns, among the shadowy walls, the damps, the smells, the sounds; among the bellowing beasts in the churning waters about me, and into the storm of wings and tongues in the whirring air above me, I passed from the things I had known, and the time and the earth of man, into a period of the past, elemental, primordial, monstrous.

\section{II}

I had not known what to expect, because, never having seen Three-Arch Rocks, I could not know what my friend the State Game Warden meant when he said to me, "Come out to the Pacific Coast, and I will take you back to your cave days; I will show you life as it was lived at the beginning of the world." I had left my Hingham garden with its woodchuck, for the coast of Oregon, a journey that might have been compassed by steam, that might have been measured in mere miles, had it stopped short of Three-Arch Kocks Reservation, which lay seaward just off the 


\section{WHERE ROLLS THE OREGON}

shore. Instead of miles, it was zones, ages, worlds that were traveled as I passed into this haunt of wild sea-bird and beast. And I found myself saying over to myself, "Thou madest him to have dominion over the works of thy hands; thou hast put all things under his feet" - as if the words had never before been uttered in human ears, and could not yet be understood.

For here was no man-dominion; here the trampling feet of man had never passed. Here was the primeval world, the fresh and unaffrighted morning of the Fifth Day. Then, as the brute in me shook itself and growled back at the brute about me, something touched my arm, and I turned to find the Federal Warden of the Rocks at my side, - God, as it were, seeing again everything that $\mathrm{He}$ had made, everything that man had unmade, and saying again with a new and a larger meaning, Have dominion over the fowl of the air, and over the fish of the sea, and over whatsoever passeth through the paths of the seas.

And here at my side, by act of Congress, stood that Dominion, the Federal Warden, the collective, spiritual man, badged and armed to protect forever against the individual brute man the 


\section{THREE-ARCH ROCKS}

wild life of these three rocks and the waters adjacent.

But did I fully understand the Why? Did I wholly comprehend the meaning and the value of such a sanctuary for wild life? I turned to the warden with the question. That honest official paused a moment, then slowly answered that he 'd be hanged if he knew why. He did n't see any good in such protection, his salary notwithstanding. He had caught a cormorant (one from the Rocks) not long since, that had forty-nine young salmon in its maw; and as for the sea-lions, they were an unmitigated nuisance, each one of them destroying (so it had been reckoned) five hundred pounds of fish every day.

Now the warden's findings are open to question, because there are good reasons for the cormorant's catch being other than salmon fry; and as for the lions it is pretty certain that during their stay on the breeding-grounds (Three-Arch Rocks) they do not feed at all, having come in from their deep-sea wanderings with fat enough to worry along with until their family cares are over. A bull sea-lion with half a dozen wives has his flippers full. They come in to the Rocks fat; 


\section{IO WHERE ROLLS THE OREGON}

they depart lean; and when afar on the waves the chances are few that salmon ever become their prey. Still I have no proof of error in the warden's figures. I will accept them just now, - the five hundred pounds of fish a day for the sea-lion, and the forty-nine salmon fry for the cormorant (they would easily total, four years later, on their way up the Columbia to the canneries, a half ton), accepting this fearful loss of Chinook salmon then as real, is there any answer to my question, Why? any good and sufficient reason for setting aside such a reservation as Three-Arch Rocks? for myself protecting the wild life of these barren rocks against myself?

No, perhaps not, - not if this protection of cormorants and sea-lions means the utter loss of the salmon as an industry and as an article of food. But there is an adequate and a paying catch of salmon being taken in the Columbia this year, in spite of the lions and the cormorants, as there will be again next year, for the state hatcheries have liberated over seven million young salmon this summer and sent them safely down the Columbia to the sea. No, perhaps not, - no good and sufficient reason for such protection, were I an Astoria 


\section{THREE-ARCH ROCKS}

fisherman with the sea-lions pursuing the salmon into my nets, as the imaginative fishermen say they occasionally do. Instead of an Astoria fisherman, I am a teacher of literature in Boston on the other side of the world. It is easy at Boston to believe in the value of Astoria sea-lions. It is hard anywhere not to believe in canned salmon. Yet, as sure as the sun shines, and the moon, there are some things utterly without an equivalent in canned salmon.

Among these things are Three-Arch Rocks and Malheur Lake and Klamath Lake Reservations in Oregon, and the scores of other bird and animal preserves created by Congress all the way from the coast of Maine across the States and overseas to the Hawaiian Islands. They were set aside only yesterday; the sportsman, the pelt-hunter, the plume-hunter, the pot-hunter, and in some instances the legitimate fisherman and farmer ordered off to make room for the beast and the bird. Small wonder if there is some grumbling, some law-breaking, some failure to understand. But that will pass.

In a recent dispatch from Copenhagen, I read, - 


\section{WHERE ROLLS THE OREGON}

"Americans of Danish descent have purchased a tract of three hundred acres of typical and virgin Danish heather landscape, which is to be preserved for all ages to come as a national park. The wonderful, picturesque Danish heath, which for ages has furnished inspiration to national artists and poets, has been disappearing fast before the onslaurght of the thrifty Danish farmers, who are bringing every available square inch of Denmark's soil under cultivation. One day it dawned upon the Danish people that soon there would be nothing left of this typical landscape, and while the good people of Denmark were discussing ways and means of preserving this virgin soil, Americans of Danish descent had already had a representative on the spot who had bought up from a number of small landowners the threehundred-acre tract known as Rebild Bakkar [Rebild Hills], considered the most beautiful part of the heath, besides having historical associations dating hundreds of years back."

I am sending the cablegram to the warden of Three-Arch Rocks and to the Astoria fisherman, and to myself, underscoring these lines, -

"The wonderful, picturesque Danish heath, 


\section{THREE-ARCH ROCKS}

which for ages has furnished inspiration to national artists and poets, has been disappearing fast before the onslaught of the thrifty Danish farmers, who are bringing every available square inch of Denmark's soil under cultivation."

Three hundred acres of inspiration to artists and poets (and to common people, too), or three hundred acres more of vegetables, - which will Denmark have?

Now, I have a field of vegetables. I was born and brought up in a field of vegetables - in the sweet-potato and cabbage fields of southern New Jersey. To this day I love - with my heart and with my hoe-a row of stone-mason cabbages; but there are cabbages on both sides of the road all the way home, not fewer cabbages this year, but more, and ever more and more, with less and ever less and less of the virgin heather in between.

The heather is for inspiration, for pictures and poems; the cabbages are for cold-slaw and sauerkraut. Have any complained of our lack of cold-slaw and sauerkraut? I paid five cents a pound for cabbage at the market recently (a frozen head at that); but even so, it is abundant as compared with poetry. 


\section{WHERE ROLLS THE OREGON}

Cold-slaw and sauerkraut and canned salmon let us have; but let us also have the inspiration of the virgin heath, and the occasional restoration to our primitive, elemental, animal selves, in a returning now and then to the clangor and confusion of wild life on Three-Arch Rocks. The body feeds on cabbage. The spirit is sustained by heather. Drain for the farmer; irrigate for the farmer; but save something for the poet and painter, lest they cry out -

"Water, water, everywhere,

Nor any drop to drink."

For what will it profit a nation to lose its soul? Denmark has fifteen thousand square miles devoted to her body, and and has saved three hundred acres for her soul! What besides ThreeArch Rocks and the other wild patches have we saved?

I have not convinced the warden, doubtless; but if I have encouraged him to perform his duty, then that is something. And well he knows the need for his guard. The sea was without a sail when we steamed in toward the Rocks. We had scarcely landed, however, when a boat hove 


\section{THREE-ARCH ROCKS}

in sight, and bearing down upon us, dropped anchor within rifle-range of the lion-herds, the men on board ready with their guns for an hour's sport!

1. "Thou hast put all things under his feet"; and the feet have overrun and trampled down all the things except in a few scattered spots where the trespass sign and the warden are keeping them off. I followed these feet over the last-left miles of wild Canadian prairie, over a road so new that I could see where it crossed the faint, grass-grown trails of the buffalo. I followed the feet over the Coast Range mountains, through the last-remaining miles of first-growth timber, where the giant boles, felled for the road, lay untrimmed and still green beside the way - a straight, steelbordered way, for swift, steel-shod feet that shake the mountain and the prairie in their passing, and leave behind them, down the trail, the bones of herds and forests, the ripped sod, the barbed wire, the shacks that curse the whole horizon, the heaps of gutted tins, and rags, and scrap unburied offal, flung from the shanty doors with rose-slip and grain of wheat, to blossom later in the wilderness and make it to rejoice. 


\section{I6 WHERE ROLLS THE OREGON}

Only it will not be the wilderness then, or the solitary place; it will not be prairie or forest. The fir tree will never follow the rose, nor the buffalo-grass the great gasoline tractor. I have seen the last of the unploughed prairies, the last of the virgin forests. It was only a few weeks ago that I passed through the mountain forest, and to-day, as I am writing, those age-old trees are falling as the summer grass falls across the blade of the mower.

This, I know, must needs be. All of this was implied, delegated, in the command, "Be fruitful, and multiply, and replenish the earth, and subdue it." No, not all of this needs to be; nor ought to be.

“ - O River,' said Mary,

-Why will you not stay,

And tell me the things

That you see on your way?

“ ‘ Oh! why must you hurry,

The day is so long;

Pray, rest a short time

And sing me a song.'

" ' My child,' said the River,

- If I stay with you,

Why, what will the grasses

And sweet flowers do ? 


\section{THREE-ARCH ROCKS}

"c ' The mills must be turned;

Ships taken to sea;

And the news of the day

Must be carried by me." ",

The river is right, though the child can hardly understand; and the child, too, is right, - will the river ever understand? The mills of men must be turned, their ships must be taken to isea, but the child, the eternal child, must be told a story, must be sung a song. For what does a child know of mills? It cannot live by wheaten bread alone.

The river is turning my mill, for I (the mortal part of me) and my children (the mortal part of them) need bread; but the heart of me, the soul of me, the immortal child of me and of my children, craves something that the harnessed river cannot grind for us, something that only the wild, free river can tell to us as we lie beneath the fir trees at its far-off head waters, can sing to us as its clear cascades leap laughing down from pool to boulder, in its distant mountain home.

The river is turning my mill. I must grind and the river must help me grind. But I must play too, and I must be told a story and be sung 


\section{WHERE ROLLS THE OREGON}

a song. Am I not a child? and do I not owe the child something? Must I put the child in the mill to grind? There are children in our mills, - little children, yes, and big children; young children, and old children, - more old children than young; grinding, grinding, grinding as our dank, dark rivers go turning on, too hurried now to tell a story, too thick-tongued to sing a song.

Here were still the story and the song, here on Three-Arch Rocks; and here they shall ever remain; a story as naked as birth, a song as stark as death and as savage as the sea, -

Birth, birth and death!

Wing and claw and beak;

Death, death and birth!

From crowded cave to peak.

\section{III}

These were Isles of Life. Here, in the rocky caverns, was conceived and brought forth a life as crude and raw and elemental as the rock itself. It covered every crag. I clutched it in my hands; I crushed it under my feet; it was thick in the air about me. My narrow path up the face of the rock was a succession of sea-bird 


\section{THREE-ARCH ROCKS}

rookeries, of crowded eggs, and huddled young, hairy or naked or wet from the shell. Every time my fingers felt for a crack overhead, they touched something warm that rolled or squirmed; every time my feet moved under me for a hold, they pushed in among top-shaped eggs that turned on the shelf or went over far below; and whenever I hugged the pushing wall I must bear off from a mass of squealing, struggling, shapeless things, just hatched. And down upon me, as rookery after rookery of old birds whirred in fright from their ledges, fell crashing eggs and unfledged young, that the greedy gulls devoured ere they touched the sea.

An alarmed wing-beat, the excited turn of a webbed foot, and the murre's single egg or its single young was sent over the edge, so narrow was the footing for Life, so yawning the pit below. But up out of the churning waters, up from crag to crag, clambers Life, by beak, by claw, falling, clinging, climbing, with the odds forever favoring Death, yet with Life forever finding wings.

I was midway in my climb, at a bad turn, edging inch by inch along, my face hard-pressed 


\section{WHERE ROLLS THE OREGON}

to the face of the cliff, my fingers gripping a slight seam overhead, my feet feeling blindly at the brink beneath, when there came up to me, small and smothered, the wash of the waves, the voice of space and nothingness and void, the call of the chasm out of which I was so hardly climbing. A cold hand clasped me from behind.

With an impulse as instinctive as the unfledged murre's, I flattened against the toppling rock, fingers and feet, elbows, knees, and chin clinging desperately to the narrow chance, - a falling fragment of shale, a gust of wind, the wing-stroke of a frightened bird, enough to break my hold and swing me out over the water, washing faint and far below. A long breath, and I was climbing again.

Yet in that instant I was born again, not a human being, but a mere being; stripped of everything except life and the clinging to life; reduced to one of my ancestral animal selves; reverting in that moment of time through the æons of my development back to the bird of me, back to my murre self, catching by chin, knees, elbows, feet, and fingers to the rocky seams for life, naked life. I was reborn a murre, fighting 
against the forces of sea and sky, to live, to cling to the rock from the wind and waves. And there was born within me at that moment more life, more sympathy with life, a new consciousness of blood brotherhood with all birds and beasts and things that live.

We were on Shag Rock, our only possible ascent taking us up the sheer south face. With the exception of an occasional Western gull's and pigeon guillemot's nest, these steep sides were occupied entirely by the California murres, - penguin-shaped birds about the size of a wild duck, chocolate-brown above, with white breasts, which literally covered the sides of the three great Rocks wherever they could find a hold. If a million meant anything, I should say there were a million murres nesting on this outer Rock; not nesting either, for the egg is laid upon the bare ledge, as you might place it upon a mantel, a single sharp-pointed egg, as large as a turkey's and just as many of them on the ledge as there is standing-room for the birds. The murre broods her egg by standing straight up over it, her short legs, by dint of stretching, allowing her to straddle the big egg, 


\section{WHERE ROLLS THE OREGON}

her short tail propping her securely from behind.

On, up along the narrow back, or blade, of the Rock, and over the peak, were the wellspaced nests of the Brandt's cormorants, nests the size of an ordinary straw hat, made of sea-grass and the yellow-flowered sulphur-weed that grew in a dense mat over the north slope of the top, each nest holding four long, dirty, blue eggs or as many black, shivering young; and in the low sulphur-weed, all along the roof-like slope of the top, were the nests of the gulls and the burrows of the tufted puffins and the petrels. The cormorants were the most striking figures of the summit, - all around the rock rim that dropped sheer to the sea they stood black, silent, statuesque. Everywhere were nests and eggs and young, and everywhere were flying, crying birds - above, about, and far below me, a whirling, whirring vortex of wings that had caught me in its funnel.

So thick was the air with wings, so clangorous with harsh tongues, that I had not seen the fog moving in, or noticed that the gray wind of Tillamook Bar had begun to growl about the 
crags. It was late, and the night that I had intended to spend on the summit would be dark and stormy, would be too wet and wild for watching, where one must hold on with one's hands so close to the edge, or slip and go over.

So we got over the rim along the south face of the cliff, up which we had climbed, and by rope descended to a small shelf under an overhanging ledge about forty feet above the waves. Here, protected from the northwest wind, and from much of the rain, we rolled up in our blankets, while night crept down upon us and out over the sea.

It was a gray, ghostly night of dusk and mist that swam round and round the crags and through the wakeful caverns in endless undulations, coiling its laving folds over the sunken ledges, and warping with slow, sucking sounds its mouthing tentacles round and through the rocks. Or was it only the wash of waves? only the gray of the mist and the drip of the rain? Or was it the return of the waters? the resolving of firmament and rock back through the void of night into the flux of the sea?

- It was a long night of small, distinct, yet mul- 


\section{WHERE ROLLS THE OREGON}

titudinous sounds. The confusion caused by our descent among the birds soon subsided; the large colony of murres close by our heads returned to their rookery; and with the rain and thickening dark there spread everywhere the quiet of a low murmurous quacking. Sleep was settling over the rookeries.

Down in the water below us rose the bulk of a sea-lion, an old lone bull, whose den we had invaded. $\mathrm{He}$, too, was coming back to his bed for the night. He rose and sank in the half light, blinking dully at the cask and other things that we had left below us on the ledge belonging to him. Then he slowly clambered out and hitched up toward his bed. My own bed was just above his, so close that I could hear him blow, could see the scars on his small head, and a long open gash on his side. We were very near.

I drew back from the edge, pulled the blanket and sail-cloth over me, and turned my face up to the slanting rain. Two young gulls that had hidden from us in a cranny came down and nestled close to my head, their parents, one after the other, perching an instant on the rock just out of reach, and all through the night calling to 


\section{THREE-ARCH ROCKS}

them with a soft nasal quack to still their alarm. In the murre colony overhead there was a constant stir of feet and a soft, low talk; and over all the Rock, through all the darkened air, there was the silent coming and going of wings, shadowwings of the petrel, some of them, that came winnowing in from afar on the sea.

The drizzle thickened; the night lengthened. Against my face lay the damp hair of my little son. He was sleeping soundly, the rhythm and rise of the tide in his deep, sweet breathing. The day of danger had brought him very close to me, so near that now I might almost have been the mother that bore him. The quiet deepened. I listened to the wings about me, to the murmur among the birds above me, to the stir of the sea beneath me, to the breathing of the sleeping men beside me, to the pulse of the life enfolding me, of which I was part and heart; and under my body I felt a narrow shelf of rock dividing the waters from the waters.

The drizzle thickened; the night lengthened; and - darkness was upon the face of the deep. 



\section{II}

THE RAVEN OF THE DESCHUTES 



\section{II}

\section{THE RAVEN OF THE DESCHUTES}

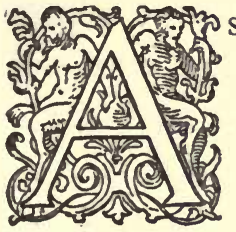

$s$ our train clung to its narrow footing and crept slowly up the wild cañon of the Deschutes, I followed from the rear platform the windings of the milk-white river through its carved course. We had climbed along some sixty miles to where the folding walls were sheerest and the towering treeless buttes rolled, fold upon fold, behind us on the sky, when, off from one of the rim-rock ledges, far above, flapped a mere blot of a bird, black, and strong of wing, flying out into midair between the cliffs to watch us, and sailing back upon the ledge as we crawled round a jutting point in the wall and passed from his bight of the deep wild gorge.

Except for some small birds in the willows of the river, this was the first glimpse of life that I had seen since entering the cañon. And I knew, though this was my first far-off sight of the bird, that I was watching a raven. Beside him on the 
ledge was a gray blur that I made out to be a nest - an ancient nest, I should say, from the stains below it on the face of the rock.

A fleck of black high up against the cliff, he yet seemed to fill the cañon. The shadow of his wings, as he flew out in the sky to watch us pass, spread up and down the valley. The smoke of our engine would quickly disappear, but the shadow of the raven's authority was the very air of these cliffs and bluffs and buttes, the spell that we had felt since the mighty walls had first shut in about us.

Or did I imagine it all? This is a treeless country, green with grass, yet, as for animal life, an almost uninhabited country. When Lewis and Clark passed here, they could find no sticks for camp-fires and lived on dog-meat - so utterly without life were the hills and headlands of the river. Such lack of wild life had seemed incredible; but no longer so after entering the cañon of the Deschutes. A deep, unnatural silence filled the vast spaces between the beetling walls and smothered the roar of the rumbling train. The river, one of the best trout streams in the world, broke white and loud over a hundred stony shallows, but what 


\section{THE DESCHUTES RAVEN}

wild creature, besides the osprey, was here to listen? The softly rounded buttes, towering above the river, and running back beyond the cliffs, were greenish gold against the sky, with what seemed clipped grass, like to some golf-links of the gods; but no creature of any kind moved over them. Bend after bend, mile after mile, and still ho life, except a few small birds in the narrow willow edging where the river made about some sandy cove. That was all - until out from his eyrie in the overhanging rim-rock flapped the raven.

The cañon was no longer empty, the towering buttes no longer bare. This was the domain of the black baron, and he held it all. No lesser land, no tamer, gentler country would fit him, somber, suspicious, unsociable, uncanny croaker of the strong black wing! It was here that I had hoped to find him, knowing that to such remote and rugged regions he had withdrawn to make his nest and live his life. How his silent flight, his black body on the shelf of the rock high up in the cañon wall, gave shape and substance to the spirit of the place! If the fir trees are a house for the stork, and the high hills a refuge for the 
wild goats, no less is the steep-walled cañon and the dizzy mountain cliff the home of the raven.

Yet the raven is the head of the tribe of crows, with all the intelligence and cunning of the crow, but lacking, it seems, the crow's easy disposition and sociable ways. Else why is it that he does not adapt himself, as the crow does, to human ways? Are we at fault? Not wholly, for we could hardly treat him worse than we have the crow. Perhaps the crows are becoming fewer; I think they are. The wonder is that a single crow is still alive in the land after all their years of persecution. But here they are, cawing in my wood-lot this quiet November day, as I have heard them since I can remember hearing anything. Here in my pines they nest, too. Could not the raven nest here, and croak here, with them?

So far as I am concerned he could. Nay, I would give him a whole wood-lot for a nest if he would come. For should I not find him, as I have at last found the crow, to be my friend and ally, instead of my enemy?

A new and better day has dawned for the birds, all birds. The greatest event, surely, that 


\section{THE DESCHUTES RAVEN}

has ever happened for American birds took place on the $4^{\text {th }}$ day of March, I9I3, when President Taft signed the Weeks-McLean bill placing all our migratory game and insectivorous birds under the protection of the Federal Government; and perhaps the greatest event that ever happened for the birds of the world took place on the night of September 3, 1913, when the United States Senate passed a measure prohibiting the importation of the plumage of wild birds into this country, except for scientific purposes.

Neither of these bills will directly protect the crow, except as they are sure to help protect all birds. But the crow will be cared for. The Government's book on the crow shows past all doubt that he is, in the long run, beneficial; that we are tremendously in his debt, notwithstanding his toll of corn; and that he must not only be allowed to dwell among us, but encouraged by every means to make himself free with our fields and woodlots.

And he will do it without encouragement. All he asks is decent neighborly treatment. He will meet us more than halfway. The light and the laws have come too late for many of our 


\section{WHERE ROLLS THE OREGON}

birds - for those that have gone forever from the earth. The State of Massachusetts has a game warden on the Island of Martha's Vineyard, who, as I am writing, is policing the haunt of the few wild heath hens there, the last survivors of a noble family of grouse that, hardly a hundred years ago, was found locally throughout southern New England and the Middle States. Have the laws and the light come too late for the heath hen?

Perhaps with this remnant we can yet save the race. In 1890 it was estimated that there were from 120 to 200 birds on the island. A few years later (1907), they had been so nearly exterminated, that only 21 were found to have escaped. To-day (1913) some three or four hundred are reported from the island. If the light and laws have not come too late, the heath hen, from this mere handful, may be increased until they have scattered themselves once more over their former haunts.

But what can we ever do for the raven? And for the birds of prey? And for such solitary creatures as the great California condor, now on the verge of extinction? 
As for the great condor, he is passing from the peaks of his mountain home because he is being wantonly shot. His great spread of wing is a mark for the hunter. $\mathrm{He}$ is being shot for the mark's sake, his carcass left to rot where it falls; while from the skies of the Sierra are snatched forever the most thrilling wings that shall ever coast the clouds.

It seems certain that the eagles and the greater hawks must pass, as being unfit for a civilized scheme of things. But the owls and the lesser hawks should remain, and along with them the wilder, shyer, more suspicious birds like the raven.

Shall he need to be educated? Or is nothing more necessary than that we show him our good faith? It may be that I have misunderstood his mind toward me. Perhaps I read things into his character that I found in a book, -

"Once upon a midnight dreary," -

when I was a child. Perhaps I have Poe's raven and the raven of the Deschutes cañon mixed in my mind. But $I$ watched him in the desert rim-rock country, and there he seemed to be the most aloof, the most alien in his attitude, of all 


\section{WHERE ROLLS THE OREGON}

wild things I have ever seen. In the high rim. rock ledges of the Blitzen River valley I watched several flocks of the big, black birds. Two specimens were shot for their skins, and for what we could learn of their feeding habits from the contents of their gizzards. One of the birds fell at my feet, his strong, wild spirit gone, and only the black form left, with its powerful beak and wise, crafty face. But even this body I took up and touched with a feeling of wonder and something akin to awe.

Surely he is too wise a bird to be driven from his inheritance because of fear of us. The grizzly bears come and go at will in the Yellowstone National Park because they know we mean no harm. The fierce spirit of the beast is led about by gentleness and by good faith, kept inviolate. If the bear, why not the raven?

John Muir, speaking of the Clarke crow of the high Sierra, a relation of the raven, says: " $\mathrm{He}$ dwells far back on the high stormbeaten margin of the forest, where the mountain pine, juniper, and hemlock grow wide apart on glacier pavements and domes and rough crumbling ridges, and the dwarf pine makes a low crinkled growth 
along the flanks of the Summit peaks. In so open a region, of course, he is well seen. Everybody notices him, and nobody at first knows what to make of him. One guesses he must be a woodpecker; another a crow or some sort of jay; another a magpie. He seems to be a pretty thoroughly mixed and fermented compound of all these birds, has all their strength, cunning, shyness, thievishness, and wary, suspicious curiosity combined and condensed."

I took it from this account that if in my mountain climbing I got a long-distance glimpse of the Clarke crow, I could count myself lucky, for is n't he the wildest of birds? On the contrary, I was amazed to find the wary creature almost eating out of my hand at Cloud Cap Inn, halfway up the side of Mount Hood. Here, on the timber-line, in the haunt of these birds, was a house, and human visitors in the summer, who fed the crows, and who had so far tamed them as to make them almost as familiar as chickens, much more sociable and trusting than our Eastern blue jays or our common crows.

If this can be done to the Clarke crow in the remote summits, it ought to be possible to tame 


\section{$3^{8}$ WHERE ROLLS THE OREGON}

the raven till he will accept a ledge from our hands or a nest-tree in our parks and groves, and with him tame every other shy, suspicious spirit that hides from hurt and destruction in the "holy mountain," when the knowledge and love of wild life shall cover the earth as the waters cover the sea.

English human life and wild life have arrived at a much closer sympathy and understanding than we, in this country, appreciate. Wild life has been protected there for centuries, and there even the raven has held on in solitary pairs, occupying for generations the same ancient trees. It seems that gradually they are dying out and may pass forever. But the English people love their birds; and how often the raven comes in for his share, both of reproach and admiration, his historians without exception endowing him with a greatness of spirit that comes close to majesty!

There is no more interesting chapter in the lives of British birds than that on the raven. I have never read anything about our American raven that shows the careful watching and the intimate knowledge of the following description of the English bird. 


\section{THE DESCHUTES RAVEN}

Says the writer:-

"They will tag with one another in midair and often tumble down a fathom or two, as if shot, to turn right over on their backs, in sheer merriment; when the wind is high, the tempestloving birds shoot up in the air like a rocket or a towering partridge, to an immense height; and then, by closing their wings, drop, in a series of rapid jerks and plunges, which they can check at pleasure, down to the ground. The male raven, while his mate is sitting, keeps anxious watch over her, and croaks savagely when any one approaches, or sallies forth in eager tournament, against any rook, or crow, or hawk, or larger bird of prey which intrudes on his domain.

"If you can manage to evade his watchful eye, and enter the wood unobserved, you can, sometimes, lie down quite still, in sight of the nest and note all that is going on. You will see him perch upon the very top of an adjoining fir tree, or whet his beak, as he is fond of doing, against one of its branches, or fiercely tear off others and drop them below. You will hear him utter a low gurgling note of conjugal endearment, which will, sometimes, lure his mate from her charge, 


\section{WHERE ROLLS THE OREGON}

and then, after a little coze and talk together, you will see him, unlike many husbands, relieve her, for the time, of her responsibilities, and take his own turn upon the nest."

The raven has but one mate; he pairs for life, and as he lives to a very great age, the strength of his affection, his tenderness and fidelity impart to him a dignity and a quality of character hardly possessed by any other bird.

All this seems to be based on a superior degree of intelligence, a quality of mind that shows itself among all the members of the raven family. It is especially noticeable among the crows. There are no other birds in my woods that seem half so intelligent and wise as they. Watch the ways of your tame crow, study the light in his eye, especially when he is up to mischief, if you would see a mind within that is pretty nearly human.

Or watch the blue jays or the magpies or the whiskey-jacks- "camp-robbers," as they are called. These lovely fluffy birds of the Canadian woods and wild Western mountains are, I think, the smallest of the family. I had an excellent chance to study their doings in the Wallowa Mountains. 
No other birds of equal curiosity and intelligence have I ever seen. Far off in the most distant wilderness, where possibly no human foot had trodden for months, we would camp, and immediately the robbers would gather, flapping out of some tall fir-top across a meadow to light upon the tree-top nearest to us. Here they would perch and squall, and find their way down to the sizzling frying-pans, to see what sour-dough bread was like, and if there might be anything left in the condensed-milk tins.

Right out of the unbroken forest they came, straight down to the fire - because they wanted to know what they did n't understand. The interest (curiosity, if you choose), the confidence, the impertinence, indeed, seemed so unnatural, unbirdlike, here where all was wild, as to be almost uncanny. No crow or raven would go to that length, because the years of persecution have taught them to temper their curiosity with extreme caution; but both birds, and all the members of the family, are at heart friendly, and would get on well with us, would we show ourselves neighborly.

And they shall get on with us. For the first 


\section{WHERE ROLLS THE OREGON}

time since the slaughter of wild life began on these shores the country as a whole has been aroused to the need of instant and country-wide protection. The Federal Government has acted. As I am writing these lines, the custom-house officers are snipping off the lovely aigrettes from the hats brought into our ports from abroad. The women are weeping and wringing their hands and doing more violent things at the wicked destruction of the costly plumes; but could they see the white heron rookeries with the heaps of rotting carcasses, and the nests of piping, starving young, could they see the plumes stripped from the brooding mothers' backs, they would understand; and no more would they make themselves the occasion for such cruel, unspeakable destruction.

And so it will soon be with us in our feeling for the new federal laws prohibiting the shooting of the migratory birds. A few hunters think that their rights (to kill the wild birds that fly over and belong to us all, but to no one person) are being encroached upon. But they will learn better soon. And soon we shall all of us learn better how to live with the birds and other wild things, 


\section{THE DESCHUTES RAVEN}

and let them live with us. We are only beginning to realize our deep dependence upon our wild neighbors, and the birds especially. As this knowledge grows, and as our love for wild life grows, we shall draw closer and closer together, we shall share and share alike, birds and beasts and men, all the things we have. We shall even learn to make all of our aigrettes - of horsehair! Then in that day (if he can find him a dwellingplace until that day come) even the raven, the wild black prince of birds, shall build his nest without fear of the trains that thunder through the cañon far below him, and without harm from the shepherds whose flocks feed in the sage back on the wide plains above. 



\section{III}

FROM BEND TO BURNS 



\section{III \\ FROM BEND TO BURNS}

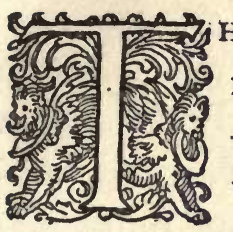

HE clutch snapped in with a jump; forward, backward shot the lever - we were rounding a corner in a whirl of dust, Bend behind us, and the auto-stage like some giant jack rabbit bounding through the sagebrush for Burns, one hundred and fifty miles across the desert.

Think of starting from New York for Wilmington, Delaware, or from Boston for New Haven, Connecticut, with nothing, absolutely nothing but sagebrush and greasewood and stony lava ridges and a barely discernible trail in between! with a homesteader's shack for Providence, another shack for Norwich, and sage, sage, sage!

It was the size of the West and the spirit of the West - this combination of sage and automobile - that struck me as most unlike things back East, size and spirit commensurate. The difference was not one of race or blood. The new Northwest has very largely come out of the 


\section{WHERE ROLLS THE OREGON}

older East, the same blood there as here; but a different spirit. Spirit is an elastic thing; and if we had the spaciousness of that western country, we should doubtless have the soul to fill it, as the little town of Burns fills it for a hundred and fifty miles of sage, whichever way you go.

We were "going in" from Bend, over the High Desert. We were to speak to the Rod and Gun Club of Burns. We were to visit the great Malheur Lake Reservation just south of Burns, and the vast wild lands of the Steins Mountains on farther south, which the State has since turned into a wild animal reservation. We were also bringing in with us a carload of young trout to stock the Silvies River and the creeks about Burns.

Our telegram had gone around by Baker City, Sumpter, and $\mathrm{Cañon}$ City; thence had been relayed by telephone to Burns; our carload of fingerling trout was to follow us by auto-truck from Bend over the desert; and we - the July morning found us heading over an horizon of gray sage into the sunrise, the purplish pine stems of the Deschutes Forest Reservation far to south and west of us, and over them, in the far north- 
west, the snowy peaks of Jefferson and the Three Sisters.

There was nothing else to be seen; not at this point, that is, for we were but just starting, and were using all our eyes to hang on with.

I had never ridden from Bend to Burns by auto-stage before, and I did not realize at first that you could hold yourself down by merely anchoring your feet under the rail and gripping everything in sight. It is a simple matter of using all your hands and knees and feet. But at the start I was wasting my strength, as, with eyes fixed and jaw set, I even held on to my breath in order to keep up with the car.

The desert was entirely new to me; so was the desert automobile. I had been looking forward eagerly to this first sight of the sage plains; but I had not expected the automobile, and could see nothing whatever of the sagebrush until I had learned to ride the car. I had ridden an automobile before; I had driven one, a staid and evengoing Eastern car, which I had left at home in the stable. I thought I knew an automobile; but I found that I had never been on one of the Western desert breed. The best bucker at the Pendleton 


\section{WHERE ROLLS THE OREGON}

Round-up is but a rocking-horse in comparison. I doubt if you could experience death in any part of the world more times for twenty dollars than by auto-stage from Bend to Burns.

The trail takes account of every possible bunch of sagebrush and greasewood to be met with on the way. It never goes over a bunch if it can go around a bunch; and as there is nothing but bunches all the way, the road is very devious. It turns, here and there, every four or five feet (perhaps the sagebrush clumps average five feet apart), and it has a habit, too, whenever it sees the homesteader's wire fences, of dashing for them, down one side of the claim, then short about the corner and down the other side of the claim, steering clear of all the clumps of sage, but ripping along horribly near to the sizzling barbs of the wire and the untrimmed stubs on the juniper posts; then darting off into the brush, this way, that way, every way, which in the end proves to be the way to Burns, but no one at the beginning of the trip could believe it - no one from the East, I mean.

The utter nowhereness of that desert trail! Of its very start and finish! I had been used to start- 


\section{FROM BEND TO BURNS}

ing from Hingham and arriving - and I am two whole miles from the station at that. Here at Mullein Hill I can see South, East, and North Weymouth, plain Weymouth, and Weymouth Heights, with Queen Anne's Corner only a mile away; Hanover Four Corners, Assinippi, Egypt, Cohasset, and Nantasket are hardly five miles off; and Boston itself is but sixty minutes distant by automobile, Eastern time.

It is not so between Bend and Burns. Time and space are different concepts there. Here in Hingham you are never without the impression of somewhere. If you stop you are in Hingham; if you go on you are in Cohasset, perhaps. You are somewhere always. But between Bend and Burns you are always in the sagebrush and right on the distant edge of time and space, which seems by contrast with Hingham the very middle of nowhere. Massachusetts time and space, and doubtless European time and space, as Kant and Schopenhauer maintained, are not world elements independent of myself, at all, but only a priori forms of perceiving. That will not do from Bend to Burns. They are independent things out there. You can whittle them and shovel them. They 


\section{WHERE ROLLS THE OREGON}

are sagebrush and sand, respectively. Nor do they function there as here in the East, determining, according to the metaphysicians, the sequence of conditions, and positions of objects toward each other; for the desert will not admit of it. The Vedanta well describes "the-thing-in-itself" between Bend and Burns in what it says of Brahman: that "it is not split by time and space and is free from all change."

That, however, does not describe the journey; there was plenty of change in that, at the rate we went, and according to the exceeding great number of sagebushes we passed. It was all change; though all sage. We never really tarried by the side of any sagebush. It was impossible to do that and keep the car shying rhythmically - now on its two right wheels, now on its two left wheels -past the sagebush next ahead. Not the journey, I say; it is only the concept, the impression of the journey, that can be likened to Brahman. But that single, unmitigated impression of sage and sand, of nowhereness, was so entirely unlike all former impressions that I am glad I made the journey from Boston in order to go from Bend to Burns. You lose no time getting at the impression. It 
begins in Bend - long before, indeed, being dis. tributed generally all over this Oregon country. At Bend the railroad terminates. The only thing you can do at Bend is to go back, - unless you are bound for Burns. The impression does not begin at Bend, and it does not end at Burns. It only deepens. For at Burns there is not so much as a railroad terminus. You cannot go back from Burns, or "out," as the citizens say, until there are enough of your mind to charter the auto-stage. The next railroad terminus to Burns is at Vale, east-northeast one hundred and thirty-five miles of sage beyond.

Not split by time and space, and free from all change, single, deep, indelible, gray is the desert from Bend to Burns.

It was 7.10 in the morning when we started from Bend, it was after eight in the evening when we swung into Burns. At noon we halted for dinner at a rude road-house, half of the journey done; at one o'clock we started on with a half of it yet to go - at the same pace, over the same trail, through the same dust and sun and sage, the other car of our party, that had followed us so far, now taking the lead. There were details enough, 


\section{WHERE ROLLS THE OREGON}

there was variety enough, had one but the time and the eyes to see. I had neither. This was my first day in the desert; and it was the desert that I wanted to traverse - it was the sage and the sand, the roll, the reach to the horizon, the gray, sage gray, that I had come out to see. I must travel swift and look far off. For you cannot compass the desert horizon at a glance. Nor can you see at a glance this desert gray; it is so low a tone, a color so hard to fix. I must see sage gray until it should dye the very grain of my imagination, as the bitter flavor of the sage stains the blood, and tastes in the very flesh of sage hen.

A day was not long enough; one hundred and fifty speeding miles could not carry me fast enough or far enough to see the desert. And if I should stop to look for the desert life, for the parts, I should miss the whole. But I had my hand instinctively upon the driver's arm when a sage sparrow darted in front of the car. It was a new bird to me. Then a sage thrasher flitted away and alighted as the car sped past - another new bird! A badger drew into its burrow - I had never seen the badger at home; a lizard, a small horned-toad, a gray-and-yellow-winged grasshop- 
per, a picket-pin - two - three of them-all new, all children of the desert! A little shrike, a cluster of squat golden-balled flowers, a patch of purple things close to the sand giving a drop of color to the stretch of gray, a slender striped chipmunk, a small brown owl dangling between the sage clumps, and calling like a flicker, another at the mouth of an old badger's den - the burrowing owl, to be sure, and the first I have ever seen! Whir-r-r-r-r — the great sage hen! and my hand shot out again - this time at the steering-wheel. The driver only grunted, and opened the throttle a little wider if anything. He was not after sage hens; he was on the road to Burns.

If only he would blow out a tire! He did break a rear axle later on in the afternoon, and to my amazement and chagrin pulled a spare one out of his toolbox, and had it on as if it were part of the programme. But he gave me a chance to start my first jack rabbit and send him careening over the plain. I crept up on a Western nighthawk, too; I gathered the most glorious of American primroses, white and as large as a morning-glory, but an almost stemless flower like most of the desert plants. I snatched and threw 


\section{WHERE ROLLS THE OREGON}

into the car eight other new species of desert flowers; nibbled a leaf of the sage and some of the salty shad-scale; picked up a large fragment of black obsidian, and beside it a broken Indian arrowhead of the same lava glass; saw where a coyote had been digging out picket-pins; and was trying to capture a scorpion when the mended car overtook me - and on through the sage we rolled.

Another stop like this and my desert would be lost. One cannot watch a desert. But one can watch a scorpion; and to leave the only live scorpion I had ever seen was hard. As we whirled past a camping freighter, his horses outspanned in the sun, I envied him the ten days he was taking to cover what I was being hurled across in one. To freight it across the High Desert! To feel the beating sun at midday, and at midnight the bite of the frost! To waken in the unspeakable freshness of the cold dawn to the singing of the sage thrasher; and at twilight, the long desert twilight, to watch the life of the silent plains awaken, to hear the quaking call of the burrowing owls, and far off through the shadows the cry of the prowling coyotes! 
If something else would happen to the car something serious - all four axles at once! But it was not to be. We were destined to sleep in Burns - a restless sleep, however. I would much rather take my chances next time with the occasional scorpion in the sage. We were due in Burns that night. We were to speak to the Rod and Gun Club. We were to tell them that the carload of young fish would be on the road by midnight, that we had seen the truck at Bend; that they could expect the fish surely by evening of the next day.

On we sped into the sage, on into the lengthening afternoon; the scattered juniper trees, stiangely like orchard trees at a distance, becoming more numerous, the level stretches more varied and broken, with here and there a cone-like peak appearing - Glass Buttes to the south, Buck Mountain to the north, with Wagon Tire and Iron Mountains farther off. Early in the forenoon we had passed several homesteaders' claims, spots of desolation in the desert, and now, as the afternoon wore on, the lonely settler's shack and wire fence began to appear again.

I have seen many sorts of desperation, but none 


\section{WHERE ROLLS THE OREGON}

like that of the men who attempt to make a home out of three hundred and twenty acres of High Desert sage. For this is so much more than they need. Three feet by six is land enough - and then there were no need of wire for a fence, or of a well for water. Going down to the sea in ships or into mines by a lift, are none too high prices to pay for life; but going out on the desert with a government claim, with the necessary plough, the necessary fence, the necessary years of residence, and other things made necessary by law, to say nothing of those required by nature and marriage, is to pay all too dearly for death, and to make of one's funeral a needlessly desolate thing. A man ploughing the sage - his woman keeping the shack - a patch of dust against the dust, a shadow within a shadow - sage and sand and space!

We were nearing Silver Creek, some forty miles, perhaps, from Burns, when ahead, and off to the right of us rose a little cloud of dust. I watched it with interest, wondering what it might be, until through the brush I made out a horseman galloping hard to intercept us, as I thought. I could not reach ahead with my eye to the 


\section{FROM BEND TO BURNS}

windings of our narrow road, but unless we made in his direction we should leave him far in the rear. He had measured the distance, too, for I saw him bend in the saddle and the horse sink deeper into the sage as it lay down to the race. He was going to miss us surely, for we were driving like the wind. Then he snatched off his sombrero, waved it over his head, pulled hard right to take us farther down on a curve, and sent his horse at a dead run over a ridge of lava stones, a run to rob the rest of my automobile journey of all its terrors.

Our car slowed down, as the rider, a cowboy, lurched into the road.

"I've a dying man in here - " he began, jerking his hand toward a shanty off in the sage. "Will you take him to the doctor in Burns?"

The driver did not open his mouth, but turned and looked at us. The car was crowded; both running-boards were piled with traps and luggage.

"He's dying of appendicitis," said the horseman. "An operation to-night might save him."

The gray of the evening had already spread over the desert, and at the ominous words it dark- 


\section{WHERE ROLLS THE OREGON}

ened till it touched the sage with a loneliness that was profound.

One of us would have to get off in the sage and give the dying man a place, and I, for every reason, was the one to do it. Must I confess that something like fear of that far-circling horizon, of the deep silence, of the pall of gray sage and shadow took hold upon me! Dying? A man yonder - alone?

Just then the second car, which we had passed some distance back, came up, and a long, lean man in a linen duster, who had eaten with me at the road-house, hearing the story, hurried with us over to the shack.

"I 'm a doctor," he said, leaving me unstrapping some luggage on the car, as he entered the door. He was out again in a minute.

"On the wrong side. Bad strain in the groin, that's all. He'll soon be in the saddle," - and we were racing on toward Burns, the purring of the engine now a song of distances, of wide slumbering plains of sage and sand, and, overhead, of waking stars.

The long desert dusk still lingered, but lights were twinkling as we slowed through the last 


\section{FROM BEND TO BURNS}

sandy ruts into the main street of Burns. We were met by the local game wardens and by some of the citizens of the town. Our talk was for to-morrow, Saturday, night. There was a "Booster Meeting" on for to-night. The next day I picked up on the street a little flyer.

\section{TONIGHT}

TONAWAMA THEATRE

The Harney County Rod and Gun Club Invites their friends to meet with them at Tonawama Hall tonight at 8.30 to listen to a talk by State Game Warden W. L. Finley, who is accompanied here by Prof. Dallas Lor Sharp. A special invitation is extended to the ladies.

Watcb For Big Balloon Ascension Wednesday

The ladies came; the children, too. Not all of the thousand souls of Burns were out, for they had had the "Booster Meeting" the night before; but there was a considerable part of them out, to hear of the fish, the thirty thousand trout fry which 


\section{WHERE ROLLS THE OREGON}

were coming over the desert at the town's expense to stock the Silvies River and the creeks about Burns. I say at the town's expense; at the expense, rather, of the Rod and Gun Club. But everybody belonged to the Rod and Gun Club. We had telegraphed our coming, and the gift of the fish, if the town would freight them in. The citizens got themselves together, raised the one hundred and twenty-five dollars, sent one of their men out with a five-ton truck to meet us at Bend. But the fish train was delayed, and we had come on ahead, leaving the truck to follow when the fish should get in. By this time, however, they should have been in Burns.

Yes, we had seen their man. He had come through to Bend. And the fish? They had been sidetracked at The Dalles, but were on the road had arrived at Bend, no doubt, at 9.45 last night, and must be now nearly in. Yes - they could certainly expect them by early morning, barring accidents - a fine lot of fingerlings, rainbows, silversides, and Eastern brook trout - forty cans of them!

It was an enthusiastic meeting in spite of the aired grievances of many of the Club against the 


\section{FROM BEND TO BURNS}

tightening game laws, for which the warden was largely responsible. Enthusiastic, and decidedly enlightened too, it seemed to me, by the time it closed, and the warden had had a chance to explain the meaning of the relations between the sportsman, the game, and the State, and to enforce his points with that great load of young fish coming yonder over the desert.

"Finley," said I, after the meeting, "it's a long haul for fish."

"So it is," he replied.

"Suppose they don't arrive in good shape?"

"I was thinking of that; the long stop at The Dalles, to begin with; then this desert! They were shipped from the hatchery Friday. To-morrow's Sunday. They'll never make it!"

We said no more. There was a good deal at stake for the game warden in this little town of Burns, the center of influence over a wider and a richer game country than can be found, I believe, anywhere else in the United States, fed as it is by the great Malheur Lake Reservation at the mouth of the Silvies, a few miles below.

At twelve o'clock that night I looked out into the sky. The stars were shining in the clear dark, 


\section{WHERE ROLLS THE OREGON}

and a strong wind was blowing cold from the desert. The truck had doubtless been on the road now for twenty-four hours. Where was it with its living freight, its forty cans of young fish, its two wardens, dipping, dipping all day, all night, to aerate the water and keep the fry alive? Those men had had no sleep all Friday night, none all day Saturday; they would get none tonight - all night. And the driver, the dusty, shock-headed driver who had met us at Bend! What did it mean to drive that heavy truck, with its perishing load, at top speed, without relief or sleep, over the tortuous trail and pulling sands of the High Desert clear to Burns! And all for a few thousand fish! They had been on the road for twenty-four hours. Should they arrive before morning there still could be no rest for the wardens, who must go from can to can dipping, dipping, dipping, till the fish were put into the streams!

It was the dead of night, and away yonder, miles and miles over the starlit plain they were coming, a driver and a pounding engine fighting every dragging foot of the way, and two exhausted wardens fighting every dragging minute 


\section{FROM BEND TO BURNS}

of the time for the freight in their care! Moving among the crowded cans in the lurching, plunging car, they were dipping with one hand, holding hard with the numbed fingers of the other, the desert wind piercing them and, at midnight, freezing their fingers to the metal, and coating them with ice as the water slopped and splashed upon their clothes. And this in July!

It was a cruel haul. But it is the Western way; and it is all in the day's work.

At six o'clock the next morning, Sunday, we scanned the sagebrush to the west for a sign of the coming car. There was no cloud of dust on the horizon. None at eight o'clock. None at ten. Noon came and went. Little groups of men gathered at the corners of the street or wandered in to talk with us at the "hotel." Buckboards and automobiles from distant ranches were waiting at the garage to take a can, or two cans, up and down the river twenty, thirty, forty miles away, when the truck should get in. The street was full of people-picturesque people, pure Americans all of them - " riders," homesteaders, ranchers, townspeople, waiting for the fish-car. The local baseball nines announced a game; the 


\section{WHERE ROLLS THE OREGON}

local band came out to escort them to the grounds, and, to the tune of "There 'll be a Hot Time in the Old Town To-night," went down to the field to play until the car should come.

Four o'clock. I had ceased to look or care. My one hope now was that the car would not get in, that it was a total wreck somewhere in the hopeless sagebrush of Crook County, where the road, I remembered, was next to impassable. They had mercifully had a break-down, I was thinking, when there came a clatter of hoofs, a yelping of dogs, a shout, a loud cbug-cbugging, and up to the hotel steps ground the truck, as grim an outfit as ever pulled in from a desert.

With the town a-trailing, the car went on to the garage, where the water was quickly changed and iced down, the ranchers given their allotments of the young fish, and the unclaimed cans reloaded and hurried out to the nearest running stream.

But it was too late. I emptied the first can, and a little swirl of tiny whitish fish curled into an eddy and sank slowly to the bottom. One of them darted away - another keeled, curved out on its side, gasped, gulped the water, snapped 


\section{FROM BEND TO BURNS}

himself into life at the taste, and swam weakly off - two out of eight hundred! It was so with every can.

We went back to the hotel. The driver of the truck, his clothes, hair, and skin caked with dust, his eyes bloodshot, and fearful exhaustion fastened upon his drawn face, dropped almost through my arms to a box on the sidewalk.

"Damn it!" he muttered, more to himself than to me, his arms limp, his head upon his knees, "they can pay me for the gas, and that's all they shall do."

But he got his pay for his time also. The game warden called the Rod and Gun Club together that night, and handed them back a hundred dollars, saying the State would foot the bill this time. "You take the money," said he, "and we will build some hatching troughs in Cary Garden Creek with it to-morrow. I've telegraphed for fifty thousand trout eggs in the eyed stage - you can ship them in that stage round the world and a warden to come with them to show you how they are hatched and planted. We will stock Silvies River and every stream about Burns, and do it now." 


\section{WHERE ROLLS THE OREGON}

And so they did. In true Western style they started that hatchery the next day, and before the week had passed the work was done, the eggs were on the way, every man in the town interested, and every man won over to the side of the State in its fight for game protection and honest sport.

It is a great country, that Oregon country, as any one will say who makes the trip from Bend to Burns. 


\section{IV}

THE SHADOW OF THE DESERT 



\section{IV}

\section{THE SHADOW OF THE DESERT}

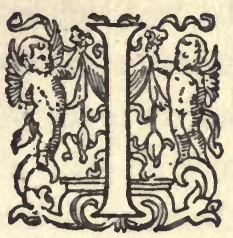

saw the desert on the trip from Bend to Burns; I had some chance to watch it in the days that followed, as again by automobile we pushed far out over the gray wastes. We were bound for Silver Lake, off about thirty miles in the sage, where the wardens had discovered a small colony of American egrets (Herodias egretta). As we left the signs of trail and travel behind us and headed straight into the desert, I saw that we were in a wilder, barrener section than any we had crossed on coming in from Bend. We were making the trip for white herons - egrets - but I began to feel coyotes about me in the sand and brush. I cannot explain just what the feeling of coyotes is, but I am sure you would have it out on the caked and crusty sand near Silver Lake. Everything said wolf as we sped silently along through the spaces of the sage. The lean, wide desert looked wolf. The 


\section{WHERE ROLLS THE OREGON}

deep silence spelled wolf. The black-tailed jacks jumped wolf as they flashed from the jaws of our own stalking car. And they ran as from wolves, when, over a smooth alkali bottom, we pushed up the throttle and sent the swift-footed machine hard at their heels. But it was the air, the aspect of things, rather, the sense of indescribable remoteness, withdrawal, and secrecy ever retreating before us, that seemed to take on form as something watchful, suspicious, inherently wild, something wolf-like. This was the wildest stretch of land, the most alien, that I had ever seen, and it must be here, if anywhere in the Northwest, that I should see the coyote, the desert wolf.

And I could see one, if anybody could, for I had the help of all the imagination necessary. I had grown up on wolves - book wolves. How many scores of times have I been treed by them! How many more than scores of times have I been forced to cut loose my lead-horse for the pack to fall upon, while I galloped ahead through the snowy forest toward the settlement! The homesteader and the trapper have had small wolf experience compared with mine. For night after night I have heard the curdling cry of the pack, have been 


\section{THE SHADOW OF THE DESERT 73}

driven deep down under the covers of the bed, as the north wind went howling through the stiff pines outside my window, or some neighbor's dog sat baying at the moon.

It matters little what happens to a boy after he has finished "Robinson Crusoe" and closed the covers of "Bad Lands Bill; or, The Bucket of Blood." It is too late for wolves after that. After that he might be eaten alive by wolves without knowing what was rending him. Years, growth, knowledge, experience - what is it all but the soul of childhood being clothed upon with clay? - the lolling, panting wolf-pack through the timbered bottoms of the imagination taking shape as a slinking coyote in the greasewood of the desert? Blessed is the man who had packs of wolves after him as a child, for his coyotes will never become jackals and foxes, and if there is a coyote in the desert he shall see a wolf!

But any one might see a coyote here. The creature's tracks were plain in the sand. He lurked behind every rise we topped, in every gully we cut, beyond every flat we crossed. By and by we fled through the caked and cracked bottom of some evaporated alkali lake, rounded a low rim 


\section{WHERE ROLLS THE OREGON}

rock into a green meadow, or coulée, and sighted the dull dead water of Silver Lake with its scalded shores bare and bleaching in the sun. A low edging of rock, the broken footings of a wall, ran around the shallow basin like a rude beading about some vast pewter salver. The thick water was rapidly shrinking. Off in the middle lay an island about a hundred acres in extent, at one end of which, on the surface of the lake, rested a great flock of white pelicans, and gleaming like flecks of snow against the green willow copse at the opposite end of the island perched a few white herons. The warden stood speechless at the sight of snow-white birds in the willows - they had been so nearly exterminated by the plumers, - and his wonder fell upon us all.

We had left the car behind the wall of rock, allowing, for the first time, the absolute silence of the desert noon to come upon us. It was a new kind of silence to me, as utterly unlike any that I knew as the-desert itself was unlike any stretch of my native landscape. One knows his silences as well, and listens as often to them, as one knows the voices of his birds, or the sounding tongues of stream, or storm, or forest, or shore. 


\section{THE SHADOW OF THE DESERT 75}

Take the three familiar silences of winter: the sudden hush that falls at twilight on the coming of the first frost; the breathless suspense, full of foreboding, that awaits the breaking of a winter storm; the crystal stillness - that speech of the stars - pervading earth and sky on a brilliant frosty night! These all differ from the summer silences, as even the drowsy quiet of an August noon over my Eastern fields differed from this dearth, this death of sound here in the desert, where the taut silence seemed drawn like shrunken skin over the bones of the sand and sage.

As we picked our way across the broken rock about the shore, a rattlesnake made the silence shiver; an avocet flew up with a note of woe, and then all was still again, the bones of cattle which lay scattered over the shallow valley quite as capable of stirring as any living thing in sight. Yet there was something stirring - yonder - a gray-brown shadow, far off on the alkali crust, a loping, backward-looking figure which halts at the edge of the brush, then leaps the rocky rim and is lost - the coyote!

I stood staring after him when the automobile, having also climbed the rocks, came up and 


\section{WHERE ROLLS THE OREGON}

whirled us over the flats to the distant side of the lake, where we were going to wade across to the egret colony on the island. I was soon in the water, stepping in the prints of the coyote which plainly showed beneath the surface, deep in the elastic, cement-like mud, and which led straight for the colony of the egrets. I was about halfway over, when a pistol shot rang out behind me and I turned in my tracks to see a coyote scurrying away from the automobile on three legs.

Doubtless it was the one that only a few minutes before I had seen disappearing in the sage and rabbit-brush a mile away. He had followed us, had seen us well into the lake, and, thinking we all were gone, had trotted boldly out to inspect the car, the first automobile, I imagine, to penetrate to this desert haunt of his. But our driver was lying in the shade beneath, the car, watching, and when the coyote came within easy range, fired at him, breaking his fore paw evidently, by the way it dangled as the poor beast spun about and dashed for the rocks.

He was a wolf, to be sure; but a wolf, if not an earth-born companion, is at least a fellow-mortal; and I turned again to following the clean, sharp 


\section{THE SHADOW OF THE DESERT 77}

footprints in the ooze, sorry for the dangling paw. It made no difference that the tracks led straight to the precious egret rookery, where they showed clearly enough what a scourge to the desert birdlife the creature must be. Lodged in a part of the willows was the body of a night heron, and underneath a great trampling of tracks. The carcass hung just out of the wolf's reach. A hundred times he had leaped for it, as no doubt, a hundred times he had crouched beneath the flimsy platforms in the matted willows, waiting for a nestling or an egg to fall. Out in the lupine and marginal grass we found a Canada goose nest, the nest of a Wilson's phalarope, and two or three mallards' nests which he had rifled. All of this was to the creature's discredit. I might heartily wish him dead; but I could not see him running maimed into the desert without pity and without protest against the careless shot.

You cannot follow the wild trails far without the conviction that the human hunter is the cruelest of all the beasts of prey. You will wonder if, for every creature killed, one has not got away wounded to die a dozen deaths in the brush. I am frequently coming upon the maimed and 


\section{WHERE ROLLS THE OREGON}

dying. Every woodsman and warden is reporting them. You cannot follow the sportsman far without foreseeing still longer closed seasons, much stricter regulations of all shooting, and even moral tests, and tests for marksmanship, before men with guns shall be allowed to go without official attendance into the woods. More than that, if you will follow the sportsman far enough, you will lose much of your taste for blood; you will be forced to the conviction that the pursuit of wild things no longer has its legitimate nor its most thrilling consummation in the kill. By the very nature of things there must be less killing, while, at the same time, there is bound to be an ever increasing multitude of those who love to hunt, and who may hunt but who must not kill; for there is a better way, without the chance of misery, and yithout the certain extinction that dogs the heels of the hunter as sure of his shadow. We are individually responsible, even while we put upon the State the burden for this better mind.

The driver of our car only laughed when I wondered how long the coyote with the broken leg might live. "He'll catch lizards and horned 
THE SHADOW OF THE DESERT 79 toads and picket-pins," said the man; "you need n't shed any tears over him. But the jacks will have the laugh on him all right." So they will, for they are his food, having been made for the coyote as the shad-scale and the settlers' oats were made for the jack. But they were made for four-legged coyotes, not for those with only three legs. The coyote works for a living, and he goes hungry many a night with plenty of jacks about him in the sage. Head as well as heels are necessary to catch the rabbit for a jack-rabbit pie; and if the coyote is a cunning, long-headed wolf, he has the even chance of his hard desert life to thank for it. The pursuer always has an advantage over the pursued, a moral handicap granted by Nature to offset the physical one allowed the pace-maker - a narrow margin usually, and so narrow between these two of the desert that, while the coyote might pull down the jack in a straightaway run, life for him at such a pace would hardly be worth living. It is lean enough at best.

As I watched the wind scoop and pile the sand about the butts of the sagebushes, or saw the white drift scud and curl across the open; as I 


\section{WHERE ROLLS THE OREGON}

smelled the alkaloid vapors rising from the leprous lake, and felt the scurvy salt-grass and the scabby crust crack under my feet, I could only marvel at life - that the sagebrush and the jack and the coyote could find a living in the wilds of this desert death. So far as I could discover, there was no live thing, not even algæ, in the water of the lake; but here and there the rib of some starved steer, or a horn, protruding from the surface, as other bones, in whitened heaps, lay scattered about the shore. The white egrets and the pelicans crossed the desert to Harney and Malheur Lakes for their fishing. To find one's self with four good feet in a land like this were desperate enough; the odds are too many against the coyote with only three.

One would know by the head and face of the coyote that he is among the wisest and most capable of animals, schooled to privation and hardship, and able to hold his own, not only with the desert, but with the homesteader as well. $\mathrm{He}$ is doomed to disappear, utterly perhaps, for he is just enough larger than the fox and just enough more of a nuisance in a settled community to make himself the enemy of the farmer and the 


\section{THE SHADOW OF THE DESERT 8I}

rancher who might overlook the smaller trespass of Reynard. Yet his presence seems needed upon the desert, for though a killer of poultry and lambs, and even of young calves, he is no such plague to the farmer as is the jack rabbit, whose only natural check, besides disease, he seems to be. The coyotes, a few years ago, were numerous about the town of Burns. We had gone thirty miles into the desert before seeing this one at Silver Lake. Left without their natural enemy, not only the jacks, but the little ground squirrels, or picket-pins, also, have so multiplied on the farms about the town as to become a plague. These squirrels are to be seen in the roads by half-dozens; and I inspected one alfalfa meadow that was literally honeycombed with their tunnels, the crop so badly cut into that the damage could be seen at a glance. The farmer can more easily protect himself against the coyote than against the rabbit and the picket-pin.

This does not settle the problem of the coyote; and he is only one item in the very complicated and very serious problem of the unbalanced state of things everywhere in nature due to our taking over the affairs outdoors. That the sportsmen 


\section{WHERE ROLLS THE OREGON}

and game wardens hate him is natural. The loss of bird-life in the ten-mile range of a pair of hunting coyotes must be fearful, and when the ranges overlap, as usually they do, with two pairs or three pairs of the keen, hungry brutes quartering the territory, nothing but the nests out of reach in the trees can possibly escape. In the story of "The Coyote of Pelican Point" I have given an account of an exceptionally troublesome creature that preyed upon the bird colonies of Tule Lake southeast of the Klamath Lake Reservation, threatening the annihilation of the birds nesting in the grass about the shore and on the low lava rocks of a point that ran into the lake. The story is a story, the actual end of the creature not being as there recorded, but the havoc he wrought, and the difficulty experienced in trying to kill him, his cunning and craft when traps were set for him, and dogs sent after him, are in no wise colored, the facts having been given me as there put down. This fellow lay in the lap of luxury, the abundant wading birds of the lake, such as stilts and killdeer, and those swimmers, like the ducks and geese, that build in the marginal grass, being his easy prey; the gulls and 


\section{THE SHADOW OF THE DESERT 83}

other swimmers, such as terns and pelicans and cormorants, escaping him, in most part, by treading down the tule islands in the middle of the lake and on these rearing their young.

But it takes the wide prairie, or the desert, to bring out the best in the coyote. $\mathrm{He}$ is the hunter of the plains, the rich grass or stunted sage or scattered rocks hiding him equally well, and yielding him his meager but sufficient meat. Fitted for the plains, he lives where almost any other carnivore would die, combining in himself the physical and mental characteristics of both fox and wolf. Sagacity and endurance mark him, and a peculiar ingenuousness, inquisitiveness perhaps, that leaves his face without a trace of savagery. $\mathrm{He}$ is pretty nearly a dog, and in fact is the one member of his wild tribe that has a welldeveloped bark. And, like the dog, he loves to bark, the dusk and moonlight filling his soul with a solemn music that every sojourner on the plains has listened to. No more weird or haunting note was ever heard, eerie, wistful, melancholy, as if the inarticulate tongue would utter things unutterable, dim brute desires that our human tongues long since have clothed with words. I have never 


\section{WHERE ROLLS THE OREGON}

seen the timber wolf at home, nor ever heard his "hunting song," but those who have tell me that it is one of the fearful sounds of the forest, sinister and savage. The little red fox that trots across my fields daily, and that frequently "barks" outside my window, has a voice as wild as the wolf's, a raucous, raw, uncultivated, untrained yap which I doubt if even the dogs of the neighboring farms recognize as belonging to one of their tribe, so indescribably alien does it sound, breaking in upon the faint puff, puff of the engine off beyond the woods, or the muffled passing of an automobile on the distant highway, or the murmur of church bells rising and falling over the fields. The coyote is more wolf than fox, but more dog than wolf, and his lonesome baying beneath the desert moon, so strangely touched with sentiment, so filled with longing, would blend better with the human sounds of my twilight than it does with the savage silence of the plains. It is a brute voice, but so nearly human, as it calls to me across the sage and shadows, that I could answer and, it seems, be almost understood.

The coyote became a denizen of the desert, no doubt, by necessity, the larger gray wolf, whose 


\section{THE SHADOW OF THE DESERT 85}

tastes and habits were similar, taking the better stocked timber and bottom lands and forcing the coyote into the open prairie and the sage plains to make whatever shift he might. $\mathrm{He}$ has been equal to it, the hardness of his desert life, I like to think, making a better wolf out of him. I say wolf, and the better the wolf the more we may hate him. But one cannot help admiring many of his ways and traits.

The exigencies of desert life have made mutual help and team-work necessary among the coyotes, two of them hunting together more successfully than one, a fact that perhaps explains their mating and staying together from year to year. It is generally supposed that coyotes mate for life, the pair appropriating an old badger's burrow, or even digging one of their own, and then, with squatter's rights, taking for their own hunting-grounds enough each way from their den to support them. These haunts, of course, overlap, two or three pairs sometimes getting together in a hunt; but generally the coyote works alone, or in single pairs, each pair's own range being apparently respected by the near neighbors.

There are few chapters of natural history more 


\section{WHERE ROLLS THE OREGON}

interesting than those describing the team and relay hunting of the coyote, especially when antelope are the game. Dr. L. E. Hibbard, of Burns, an authority on the wild life of the desert, told me of a hunt of coyotes that he had a hand in, which illustrates not only the cunning of the hunters, but the remarkable love and courage of the mother antelope as well.

Dr. Hibbard was in the desert for young antelope and had been scouring the sage for hours, when, coming up to the edge of a sharp rim rock that dropped into a flat, he looked down upon the thick sage and saw an old doe antelope with three young ones which she was trying to hide. The kids seemed to be about two weeks old - old enough to be able to run with the mother, but for some reason she was anxiously trying to conceal them. Then he saw that one of the three was lame and could not run, that this one was perhaps not the mother's own at all, but a motherless cripple that had adopted her or that she had adopted and was trying to rear. Her own two (if these two were hers) could have followed her; it was on account of the cripple that she was trying to hide them. But they did not wish to hide. They were 


\section{THE SHADOW OF THE DESERT 87}

too old. Speed had already come to their winged legs, and speed was the very breath of their young lives. Yet they must hide. She would stop and nurse them - all three of them - and lie down with them until they would separate and get out of sight under the sage, or more generally on a floe of rock similar in color to themselves; then, teetering, peeking, spying behind her, she would edge quietly away, and steal off just like a poorly trained human mother tiptoeing out of a room from her sleeping child. She would not get far before up would come their little ears, then their noses, then up they would jump and make after her.

Again she would lead them on until she found a good hiding-place, then down they would go, the whole sleeping-child performance gone through with again, to be spoiled again by the restless little kids hopping out of their beds and calling "Mamma!" Over and over mamma tried to hide them, moving off the flat in her efforts, and down a narrow valley, the watcher on the rim rock following her quite unobserved.

The repeated attempts had taken the antelope several miles down the valley to where it opened 


\section{WHERE ROLLS THE OREGON}

out into a wide sage flat. She had led them on for perhaps a mile, when, coming to a dense patch of rabbit-brush, she put them to bed again, this time successfully, for immediately her legs began to twinkle as, whisking past the hunter, hidden in a low juniper some distance out in the flat, she. made off up the valley.

Marking the spot where the young were hidden, Dr. Hibbard was climbing down toward them, when he heard a sharp blat and saw the three young antelope tearing down the trail toward him, the lame one falling a little behind. At the same time he saw the old antelope, her hair puffed, racing at top speed back toward him and the coming young ones and, down a parallel trail through the sage, running neck and neck with the mother, three coyotes, who had evidently been watching the whole affair from the edge of the rim rock.

It was a race between the mother and the coyotes to reach the young ones first, though she kept just in front of the wolves as if to keep them back from the kids. But the coyotes were at her heels, and as they neared the kids, one of the three brutes, outrunning the others, came up at her 
THE SHADOW OF THE DESERT $8 g$

side and, cutting in ahead, leaped for one of the little fawns. He seized it by the neck, but as he did so he received a terrific shoulder stroke from the mother, who, with a twist in midair, leaped at him as he leaped at the kid. The blow broke his hold upon the kid. It rolled over and over, flashed to its feet without ceasing its forward motion, and was off, while the mother, quick after the shoulder blow, fetched the coyote a racking dig in the ribs with all four of her sharp hoofs that sent him spinning and snapping heels over head in the sage.

Then the race for life was on again. The doe, now leaving two of the kids to their wits and their heels, hung at the side of the crippled one, which the wolf had attacked. The coyote was with her, watching for an opening; but her defense was marvelous, she and the kid seemed one, as hawk and sparrow seem one zigzagging through the air. She literally covered him as they darted along. But the little fellow's strength was failing. Suddenly the wolf whipped under the flank of the mother and with a long leap again caught the kid by the throat, only again to get the terrific shoulder blow and the raking 


\section{WHERE ROLLS THE OREGON}

broadside from her knife-like hoofs. She had forced him to drop his prey the second time, the kid never losing an instant in getting to his feet and running on.

But he staggered now. The chase had been going in a wide circle, bringing the runners around somewhat near their starting-place, and near to the two coyotes that had fallen behind, who, fresh for the fray, started in with their companion to finish the work. Meanwhile the two other young antelopes had run off and hid - flat to the ground somewhere, the invisible cap drawn over them, the odorless wind blowing across them - where the keen-eyed, keen-nosed coyote would have to step upon them before he could discover that they were not stones on the desert sand.

The race was almost over, however, for the little handicapped one, the mother bravely beating off the wolf in her desperate fight to save the bleeding, tottering thing. The coyote was still afraid of her shoulder and her terrible hoofs, but now merely dodged her strokes, growing bolder as the kid came tottering to his knees, when again he leaped and seized it. 
THE SHADOW OF THE DESERT 9I

At this point the companion of Dr. Hibbard came shouting up and prevented the doe from again attacking the wolf, which, hoping to escape from the man, held his prey and flattened himself to the sand. But the hunter rushed at him with stones, and the coyote, dropping the kid, ran into the sage. The other two coyotes now joined him, circling about the man, who was without a gun, as they tried to find the little antelope. But he finally drove them off. The poor little kid, however, was dead, its throat torn by the fierce fangs that the mother repeatedly had broken from their fatal hold.

But the other two kids escaped-only to fall later, perhaps to the same fangs. It was a close call - as it will be the next time, as it always is on the desert and here in my own Eastern woodlot, and elsewhere, everywhere. I did not see an antelope in these deserts, though I traveled hundreds of miles looking for them. I had to content myself with studying a tame one at the Narrows, that had been captured in the sage. Yet a few months after my trip through the plains, the State's wardens counted several hundred antelope where I thought they must have become extinct. 


\section{WHERE ROLLS THE OREGON}

The coyote and they have always dwelt together on the desert, the hand of Nature giving differently, but giving evenly, to them both.

There used to be no shadow on the desert. Death crossed; but only Life dwelt among the rim rocks and the sage. The gray-brown shadow that I had seen on the shores of Silver Lake was no shadow at all; it was a coyote. But that evening as we left Silver Lake behind us and were speeding out through the sage, we came upon a straight, interminable line of squared pine stakes set low in the sand, the trail of the surveyor driven into the breast of the desert; and a long, interminable line of stakes cast a long, interminable shadow - the shadow of a coming railroad that lay direct and dark across the plain. 
ON THE MARSHES OF MALHEUR 



\section{V}

\section{ON THE MARSHES OF MALHEUR}

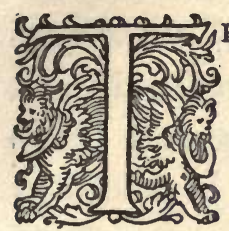

HE sedges were full of birds, the waters were full of birds, the tules were full of birds, the skies were full of birds: avocets, stilts, willets, killdeers, coots, phalaropes, rails, tule wrens, yellow-headed blackbirds, black terns, Forster's terns, Caspian terns, pintail, mallard, cinnamon teal, canvas-back, redhead and ruddy ducks, Canada geese, night herons, great blue herons, Farallon cormorants, great white pelicans, great glossy ibises, California gulls, eared grebes, Western grebes - clouds of them, acres of them, square miles - one bundred and forty-tbree square miles of them!

I was beside myself at the sight - at the sound - at the thought that such wild life could still be anywhere upon the face of the earth, to say nothing of finding it within the borders of my own land. Here was a page out of the early history of our country; no, an actual area of that 


\section{WHERE ROLLS THE OREGON}

wild, unspoiled, unslaughtered country as the Indian knew it, as Lewis and Clark saw it on that first trip across the continent.

The accounts of bird-life in early American writings read to us now like the wildest of wild tales - the air black with flocks of red-winged blackbirds, the marshes white with feeding herons, the woods weighted with roosting pigeons. I have heard my mother tell of being out in a flock of passenger pigeons so vast that the sun was darkened, the birds flying so low that men knocked them down with sticks. As a child I once saw the Maurice River meadows white with egrets, and across the skies of the marshes farther down, unbroken lines of flocking blackbirds that touched opposite sides of the horizon.

That was years ago. I had seen nothing like it since; nor did I ever again expect to see it. I had heard of Malheur Lake, when, some few years ago, the naturalist through whose efforts it was made a Federal reservation visited me and told me about it. He even brought photographs of its bird-colonies. But words and pictures gave no conception of the extent of its uncrowded crowds of life. For what could a camera do with one 


\section{THE MARSHES OF MALHEUR 97}

hundred and forty-three square miles of swimming, winging, crying birds?

Lake Malheur Reservation is in the southeastern quarter of Oregon, and is only one of several such wild-life sanctuaries within the borders of that great commonwealth. Indeed, the work being done by Oregon for the protection of wild life seems almost past belief to one used to the small things of the Eastern States. And the work there has but just begun! In 1912 the private game "refuges," where the State Game Warden has entered into contracts with owners of private land, covered an area of 143,789 acres. In addition to these small refuges there are six vast state reservations, set aside forever by the Legislature for game and bird protection, covering $1,698,320$ acres, or 2654 square miles, an area more than twice the size of Rhode Island. Besides these state reservations are the four great Federal preserves: Three Arch Rocks Reservation, off the coast; Klamath Lake Reservation, lying partly in Oregon and partly in California; Cold Springs Reservation, in Umatilla County, in the northeast; and Lake Malheur Reservation, including the waters and marshlands of Malheur and Harney Lakes, and 


\section{WHERE ROLLS THE OREGON}

situated in the midst of protecting sagebrush plains that stretch from the foothills of the Cascades eastward to the cañon of the Snake River at the foot of the Rockies in Idaho.

Separated thus by the deserts from any close encroachment, saved to itself by its own vast size and undrainable, unusable bottoms, and guarded by its Federal warden and the scattered ranchers who begin to see its meaning, Lake Malheur Reservation must supply water-fowl enough to restock forever the whole Pacific slope.

For here in the marsh of burr reed and tule, the wild fowl breed as in former times when only the canoe of the Indian plied the lake's shallow waters, when only the wolf and the coyote prowled about its wide, sedgy shores. I saw the coyote still slinking through the sage and salt grass along its borders; I picked up the black obsidian arrowheads in the crusty sand on the edge of the sage plain; and in a canoe I slipped through the greenwalled channels of the Blitzen River out into the sea of tule islands amid such a flapping, splashing, clacking, honking multitude as must have risen from the water when the red man's paddle first broke its even surface. 


\section{THE MARSHES OF MALHEUR 99}

No, not quite such a multitude, for there was no snowy gleaming of egrets in the throngs overhead. The plume-hunter had been before us, and the glory of the lake was gone. That story is one of the tragedies of bird-life, and vividly told in William L. Finley's account of "The Trail of the Plume-Hunter," in the "Atlantic Monthly" for September, 1910. He says, writing of his and Bohlman's journey into the Malheur country in 1908:

"We had hunted where one might think no human being had ever been, but long before we had traveled over these apparently unknown regions, plumers had preceded us. We followed in their trails. We camped where they had camped. We had traveled hundreds of miles exploring the haunts where white herons used to live, but up to the summer of 1908 we had not seen a single one of these birds.

"This is historic ground for the bird man. In the early seventies the well-known ornithologist: the late Captain Charles Bendire, was stationed at Camp Harney on the southern slope of the Blue Mountains, straight across the valley from where we stood. He gave us the first account of 
the bird-life in this region. He saw the wonderful sights of the nesting multitudes. He told of the colonies of white herons that lived in the willows along the lower Silvies River. There was the river itself winding across the valley through sage, rye-grass flats, and tule marshes, its trail marked by a growth of willow and alder.

"Two days ago we had followed this trail, and searched out these places to photograph the white heron. As we approached the trees, said to be alive with birds, all was silent.

"'We're on the wrong trail again,' my companion had suggested; but pushing through the willows I saw big nests in the trees on both sides of the river. Strange to say, not a single bird! I clambered up to one of the lower nests, and found a rough platform of sticks upon which lay the bleached bones of two herons. I climbed another and another. Each home was a funeral - pyre.

"'Epidemic?' said my companion. “' 'Yes, of plume-hunters!' I retorted.

"Here was a great cemetery in the silence of the marsh. But one nest was inhabited. A longeared owl was in possession sitting on five eggs. 


\section{THE MARSHES OF MALHEUR IOI}

As we approached, she spread her wings, and left without a sound. Ill-omened creature brooding eggs and bones!

"Standing here high above the valley, with my field-glass I picked out the very spot of this great bird-massacre that we had visited.

" 'I hope we find no more like that,' said my companion as he tightened the camera-straps about his shoulders, and started off down the trail toward the lake.

"We were both confident that somewhere down in that distant sea of green tules, we could find at least one place where white herons were nesting.

"We outfitted for a week's trip, and set out down the spring branch. This time we kept a straight course to the north until we reached the main body of the lake. All day long we hunted and watched the birds, lining them with our fieldglasses as they flew back and forth over the lake. We saw no signs of white herons.

"That day we found a colony where the great blue heron nested. White herons were formerly common here, both species nesting together. Not a single white bird left! 
"We spent the next four days here and there through the vast extent of tule islands and water, searching and keeping watch all day, trying to find white herons. Late one afternoon we came to a place where another big colony of blue herons was nesting. We had been seeking this place. Malheur Lake is divided in several parts by the long lines of tule islands. We were in the northern part. The colony was on two long tule islands that lined up with Pine Knob and the east end of Wright's Point. On the north end is a big canebrake.

"We sat in the boat at the edge of the canebrake, and watched the big birds as they sailed over, dropped in, and departed. We were tired from the long day's search. I did not then know the story as I know it now: but hidden in the end of this canebrake a hunter had had his blind, ten years before.

"That summer of 1898 was eventful in whiteheron history here on Malheur Lake. Early in the season two men had arrived at Narrows, bought lumber, and built a flat-bottom, double-ended boat. They set out from Narrows with a small outfit. They fought mosquitoes day and night as 


\section{THE MARSHES OF MALHEUR IO3}

we had; they drank the alkali water; they slept in the boat or on muskrat houses while they hunted up and down the waters of the lake and the tule islands. They saw the great flocks of white pelicans, cormorants, terns, gulls, grebes, and other birds. They saw the white herons in slow, stately flight wherever they went, but it was not till after several days that they located the big colony here on the island by the canebrake, the greatest colony they had ever seen. What a sight it must have been, thousands of these birds, dazzling white in the sun, coming and going from the feeding-grounds, and hovering over their homes!

"On all sides were the homes, built up a foot or two from the surface, each having three or four frowsy-headed youngsters or as many eggs. At each end of the colony a plumer sat hidden in his blind. At the first crack of the gun, a great snowy bird tumbled headlong near its own nest. As the shot echoed across the lake, it sounded the doom of the heron colony. Terror-stricken, on every side white wings flapped, till the air was completely filled. Shot followed shot unremittingly as the minutes passed into hours. Still the 


\section{IO4 WHERE ROLLS THE OREGON}

heron mothers came to hover over this scene of death and destruction. Mother-love was but the lure to slaughter.

"By two o'clock in the afternoon, the day's shoot ended. It took the rest of the day for the hunters to collect the dead and take the plumes. Stripping the plumes is rapid work. It takes but the slash of the knife across the middle of the back, a cut down each side, and a swift jerk.

"Long after dark the plumers heard the steady quacking clatter of young herons crying to be fed. Far into the night, hoarse croaks sounded over the still lake, greetings of those birds that had spent the day fishing in distant swamps. It argued good shooting again for the morrow.

"The second day was a repetition of the first. Heron numbers thinned rapidly. Here on these two islands, the plumers harvested a crop that yielded twelve hundred dollars in a day and a half. They collected a load of plumes worth their weight in gold. Were the California days of '49 much better?

"Malheur has seen many such massacres, but none so great as that. Little did we know of these facts as we sat watching the blue herons coming 
THE MARSHES OF MALHEUR 105 and going, expecting to find at least a few white herons somewhere about the locality.

"After hunting for seven days we returned to camp for more provisions, and set out to visit another part of the lake. This time we stayed out for nine days, and saw - two white herons! At the time we thought these must be part of a group that nested somewhere about the lake; yet more likely they were a single stray bird that came our way twice. I am satisfied that of the thousands of white herons formerly nesting on Malheur, not a single pair of birds is left."

It may have been two birds that they saw and not one. For he has not told all of the story yet; how in the summer of 1912 he received a telegram saying white herons (the American egret) had been seen passing over the marshes of Malheur; nor how we set out from Portland for Burns; nor how, away off on an island in the alkali water of Silver Lake, some fifty miles in the desert from Malheur, we found the birds a colony of a dozen pairs, numbering with the young about twenty-eight birds all told; nor how -

But that is for him to tell, if he will. For if the 


\section{IO6 WHERE ROLLS THE OREGON}

egret is ever again seen flying over the inland waters of the Pacific coast, it will be due to William L. Finley, to his discovery of the slaughter on his trip into the Malheur in 1908, and to his efforts which made Malheur a wild-bird reservation.

But was it, we wonder, one bird or two that he saw winging over the lake in 1908? If two birds, were they male and female? and were they the last two? and is this small colony which we discovered four years later in Silver Lake, the seed of that last solitary pair? Could it have been that the race was so nearly cut off in all this part of the world? and does it mean that slowly now, with the new protection of these better times, the egret will come back to the willows along the Silvies and at Clear Lake, and to the islands in the canebrake of the Malheur?

I think so. In the willows of Silver Lake, I counted twenty-eight birds. These are enough if they are given a chance. The life of the species, however, does not hang upon this perilously slender thread. Along the Gulf and Southern Atlantic States, and in the Middle West, small colonies are reported as surviving, mere handfuls, 


\section{THE MARSHES OF MALHEUR 107}

where the plume-hunter found immense rookeries. Bird-lovers the world over are watching these remnants with intense concern. Nowhere were the herons as nearly wiped out, it appears, as in Oregon; and nowhere will their escape and ultimate restoration seem more of a miracle.

But desert and marsh and even my little woodlot are full of miracles. The ways of Nature are not past finding out; she does not move so mysteriously as amazingly, her wonders to perform. She could not restore the American egret without a pair to work with. She never could use crows for the purpose. But given the pair of birds, then the loaves and fishes become snowy, winged things, gleaming above the marsh by thousands, and decked in bridal dress of surpassingly lovely plumes.

While here on Malheur I witnessed a sight among the grebes, that gave me further reason for my faith in the resources of Nature, open as the happening may be to a contrary interpretation.

On the day of our arrival at the town of Burns the wardens of Malheur met us with the report of a new grebe colony (these birds had also 


\section{IO8 WHERE ROLLS THE OREGON}

nearly been exterminated by the plume-hunter), which they had discovered only the day before off in the lake. We had ridden across the desert that afternoon in the teeth of a stiff wind, and the wardens, anxious to show us the new colony, were greatly concerned for fear that this wind might wreck the nests exposed to its sweep across the wide level of the lake.

For it was nesting-time and the colony had built far out on the open water in a close, continuous line a mile long and three hundred yards wide, - a community of twenty-four hundred floating nests.

The figures are true. The wardens actually staked off the colony, measured it, and literally counted the nests. I paddled along its length myself, and while I did not count, I did believe their figures.

It was to visit this colony of grebes that we wound our way through the narrow turnings of the Blitzen River out into the wider maze of the vast lake, where there was nothing to be seen but water and tules - and birds, myriads of birds. But the wardens had blazed a trail by tying the tule-tops together into big knots, which we could 


\section{THE MARSHES OF MALHEUR IO9}

see from island to island ahead of us as we paddled along.

This was on Monday. It was on Thursday the week before that the wardens had found the colony; and now, as we came out of the mouth of the Blitzen, we ran straight into a grebe colony of over a hundred nests that was not there at all four days before. One of the wardens, who was in the canoe with us, thought we must be off the course. But here were his knots in the tules. The nests had been built, all of them, since Thursday, and most of them were already with eggs.

There must be some mistake, I thought, and turned to watching the birds; for it was not the nests that interested me half so much as the anxiety of the grebes at discovering us. Every one began hurriedly pulling the wet tule stems and milfoil of the nest over her eggs to hide them before we should come up, working against her fears, and at the risk of her life, to save her eggs - to protect the seed of the race!

A racial instinct, you say, only a race act, every bird doing as every other bird did that had eggs. True, but here, as with the murres on Three-Arch Rocks, there was plainly individual action, deep 
individual concern, the mother feeling, holding some of the birds to their duty long after others had taken wing in fright.

To rob the animals of individuality - to reduce them to automata, acting mechanically according to inherited race instincts, is to reduce all life to grass and the grass almost to hay.

"Through primrose tufts, in that green bower,

The periwinkle trailed its wreaths, And ' $t$ is my faith that every flower

Enjoys the air it breathes."

And 't is my further faith that every bird and animal and insect enjoys the air it breathes, and loves and hates and woos and fights and suffers, not in the same degree, but somewhat after the manner of humans.

"To her fair works did Nature link

The human soul that through me ran."

I, too, am an automaton, a wheel in a great racemachine. I do certain things because the race has done them and continues to do them. Perhaps I have never done anything that the race has not done. Perhaps I am my whole race. Perhaps I have been in my development, since I was conceived, all the races down to the single-celled 
amœba. Yet I am; and the race is; but as for the race, I can say, "Go to!"

So the individual grebe is. The sight of these hundred feverishly pulling down the walls of their nests to cover their eggs was a very human sight, poignant, personal, and not the mechanics of race instinct at all.

The grebe builds a floating nest out in the open water. All over the bottom of the clear lake, which averaged about four feet in depth, grew the long, trailing, mosslike water-milfoil, its whorled leaves and purple stems giving a faint glow of color to the water as we looked down into it. The grebes dive to the bottom and drag up this milfoil into heaps, or cocks, about six feet across on the bottom. The cocks are barely able to float their tops above the surface. Upon the very peak of this cock they hollow out a nest about the size of a man's hat, building up the walls with dead tule stems until the eggs rest just out of the water, though many of them are partly submerged. The nests are usually so close together that their wide bases touch below, but otherwise they are entirely unanchored and at the mercy of wind and wave. 


\section{WHERE ROLLS THE OREGON}

This was the cause of the wardens' anxiety, and, halting only long enough to count the new nests and get some photographs at the mouth of the river, we pushed on up the lake.

I shall try to describe that trip sometime - the long lines of white water kicked up by the rising birds; the clapping of wings, the splashing of feet; the tule islands trodden flat by the rookeries of young gulls and pelicans and cormorants; the diving of the grebes about us; the soaring of the majestic pelicans far above us - but not any of that now.

We had paddled for an hour or two when on the water in the distance appeared a wide wash of pink, as if the clouds of a sunset were reflected there. It was the purple of the milfoil in the nests of the great grebe colony. We quickened our stroke, and as we drew nearer, marveling at the extent of it, we were struck with the silence at our coming and the absence of birds in the nests. A few were on wing; a few were seen covering their eggs; that was all. There was no clangor of the crowd, no diving multitude about us - but such a sight of destruction as I hope never again to see! 


\section{THE MARSHES OF MALHEUR II3}

Of the twenty-four hundred nests not three hundred were left. Tossed and torn, the nests had been driven by the high waves and the strong wind back upon themselves, in some places several deep, their pale white eggs by thousands scattered through the tangled débris or floating free in the water.

The rookery was an utter wreck. The birds, with the exception of a few pairs, had abandoned it - had gone, some hundred pairs of them, down to the mouth of the Blitzen and there started the new colony which we had encountered coming out.

I don't know which impressed me more - the fearful loss and waste of life here, or the thought of that quick recovery at the mouth of the Blitzen.

The birds had shown no judgment in choosing this place for their rookery. No more exposed position could have been found in the entire lake. The colony had acted blindly, stupidly; had learned nothing as a colony in their million ages of nest-building, nor ever shall learn. But how swift to begin again! How fertile in resource! How absolute to command! With the 
I14 WHERE ROLLS THE OREGON

nest done, the season's clutch of eggs laid, and incubation started, to see it all destroyed, and in less than a week to have built again and to have summoned the secret forces of life with new eggs for the new nests!

Can a man be born when he is old? No, because there is not a need for such rebirth. But if there were need, if that were the only way of preserving the race, the thing would be done.

The autumn winds strip my trees of their withered leaves, and the buds swell and leaf out again in the spring. That is the natural cycle. There is nothing mysterious about that. The caterpillars stripped them of their green leaves in July. The naked things shrank and shuddered in the burning heat, the sap standing still in their veins. Then, instantly laying hold with their manifold fingers on the subtile threads of life, they wove and fashioned and put on a new mantle, a miracle, that the span of the summer might be crossed, and the seed carried over for another spring.

It was so with the grebes. It is so with all life - each living thing a multitude, each individual its whole race latent - potent if need be.

A bare handful of the former myriads of the 


\section{THE MARSHES OF MALHEUR II5}

white herons, or egrets, are left on Malheur. I hope to make the trip again from Bend to Burns, and from Burns down to Malheur Reservation, in order to see the gleaming, shimmering flocks of the snowy creatures that I am sure shall be passing to and from their island rookeries in the cane and tules at the head of the marshy lake. 



\section{VI}

THE SPIRIT OF THE HERD 



\section{THE SPIRIT OF THE HERD}

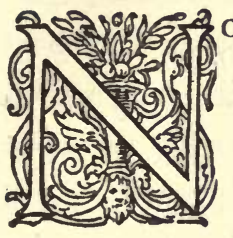

more interesting group of animals can be found the world over than those in the zoölogical garden of the average farmyard. The history of their domestication is exceedingly, humanly interesting; but still more interesting is the phenomenon itself - what it has wrought in the animals, and what it has left unchanged. For if domestication has not changed the leopard's spots, it is because the leopard has never been domesticated. There is little in the style of spots that domestication cannot change. Color, size, and shape are as clay; habits and tempers, even, have been made over. But not the creature itself, not the wild instinctive thing within the fur or the feathers: for this has hardly been touched by domestication.

That some species of animals are more amenable than others, are predisposed to domestication, is evident. Nothing in wild life is more amazing 


\section{WHERE ROLLS THE OREGON}

than the suddenness and the completeness of the elephant's yielding to the howdah and the ankus - as if his slow years had been only a waiting for some rajah to take him from his jungle. The zebra, on the other hand, though a true horse, has never been tamed, or rather, domesticated. He is irredeemably wild. So is the Asiatic ass, which stood to the ancient Hebrew writers for the very symbol of the free and untamable; whereas the Nubian wild ass (the parent of our deeply domesticated donkey) is readily brought to harness.

For many reasons, we are likely to add new species from time to time to our domesticated family. The establishment of fox-farms is pretty sure, in the end, to yield a domesticated fox; and this may yet happen even to the bison, and to many species of birds now wild. In Oregon the China pheasant is almost a domesticated fowl, and waits only to be clucked into the coop. In a ride from Corvallis to Portland by train through the Willamette Valley, just as the harvesting was done, I counted from my car-window fifty-one flocks of these magnificent game-birds feeding in the stubble-fields. They were often so near the houses, and regularly so much a part of 


\section{THE SPIRIT OF THE HERD I2I}

the farms, as to seem like "tame villatic fowl." And so, indeed, the farmers do look upon them, jealously guarding and feeding the flocks in winter and quick to resent any illegal shooting of the birds. In some parts of the East the China pheasant is as completely naturalized and almost as much domesticated as in Oregon. Here about me in Massachusetts the village folk are even complaining that the birds are raiding their gardens. They are too easily checked ever to become a nuisance here as the rabbit did in Australia or the mongoose has in Jamaica; but perhaps we shall need to adopt them, domesticate them in order to save them and protect ourselves against them. They are pretty nearly as tame as the pigeon and as ready for domestication as the guinea or the turkey must have been.

But the tame turkey is essentially a wild bird, and none of our farmyard creatures shows more strikingly than he how hardly feather-deep is the domestication which he wears. He has learned nothing new in his hundreds of years in the farmyard (he was domesticated by the Indians of Mexico long before the "discovery" of America); nor has he forgotten one of the old wild things 


\section{WHERE ROLLS THE OREGON}

he came from the woods knowing. He accepts the fenced and cluttered farm, turns it into the tall, timbered river-bottom, and lives his primal forest life among the corn-cribs and Baldwin apple trees as of old. He has not turned aside by one quill's breadth from his original wild ways. $\mathrm{He}$ roosts in the bare tops of the apple trees or along the ridge-pole of the barn, as if the jaguars and panthers were still prowling for him; he wakes in the night, gobbles, ducks, and spreads his round targe of a tail over him to ward off the swoop of the imaginary owl. He breaks the hen's egg out of jealousy, in order to prolong the honeymoon; she steals her nest from him and covers her eggs in leaving the nest, just as she used to; and when the small bands of any neighborhood are gathered into a flock to be driven to market, as they still are in the less settled parts, the old flock-spirit returns to them, and they fall into the odd migration habits of their wild forebears, who used to congregate in vast numbers in the autumn and follow the course of the river-banks, sometimes across several States, as they fed on the autumn mast.

The early accounts of their hesitancy and in- 


\section{THE SPIRIT OF THE HERD 123}

decision when stopped in their march by a river one can see paralleled any winter afternoon on the farm when the turkeys start for their roost in the tree-tops. Their absurd efforts to summon the will to fly - into the trees, on to the fence - occupied the wild flock for days together when the flight was to be across a river. On the other hand the wild turkey was as obstinate and as "set" as it was indecisive. So is the tame turkey. One of my neighbors missed a hen turkey for several days. Suspecting a stolen nest she began a search. At last she found the hen, as she expected, on the nest, but with wings and tail hard-pressed to the earth keeping off a full-grown skunk that was trying to push under her for the eggs. It was evident that she had been repeatedly attacked, perhaps for the several days, but, without food or sleep, had kept her place, beating back the spoiler at the risk of her own life. This trait often takes a peculiarly irritating turn, as the farmer well knows. Some time ago the newspapers told the story of a flock of turkeys that were being driven to market through a Southern town, when they took fright and flew into the tops of tall trees. There they stayed, defeating every effort to bring 


\section{I24 WHERE ROLLS THE OREGON}

them down. The owner, in despair of reaching the market in time, appealed to the town and sold each man his Thanksgiving turkey in the tree, the purchaser to shoot his particular bird or otherwise to fetch him down.

In a chapter of "Winter" I have described a turkey-drive in New Brunswick as it was described to me by a friend who saw it, - how the turkeys, suddenly taking a notion to go to roost, flew upon a little chapel and, in spite of the drivers, roosted there, literally covering the building, roof, belfry, window ledges, and portico, as fast as they were pushed off at one place coming back at another.

The cat, again, is as wild a case as the turkey. Stroke kitty the wrong way and she spits. Yet she sleeps in the kitchen by the fire. What of it? The very lap of her mistress has not counted with the cat in her. The cat in kitty is wild to the tip of her twitching tail. Watch her - if she has n't already scratched you - as, crouched in the grass, she takes her way toward some unsuspecting bird. A shiver runs through you. You can feel her claws - so tiger-like is she, so wild and savage, so bent on the kill. Or come upon her at dead 


\section{THE SPIRIT OF THE HERD I 25}

of night in some empty, dimly lighted alley. She is on the prowl. The light of the narrow, gulchlike street falls on her with a startling largeness and marks her silent shadow on the flags. She moves stealthily out to the corner, and, well within the shadows, stops to glance furtively up and down the open cross-street. But the people are all within the shut doors. There is no one lost on the streets for her to devour.

The other day I stood in the edge of the woods when a foxhound, hot on the fresh trail, came baying through the trees toward me, his whole body working convulsively, in an agony of eagerness, so absolute, single, and compelling was his one wild, masterful desire. He saw nothing, heard nothing, because he was tasting warm scent. I spoke to him, but I might as well have spoken to a tree. Neither hunger nor fear could stop him. He could not feel hunger or fear or weariness. $\mathrm{He}$ had forgotten utterly - gone wild. I have not infrequently seen the deep-chested foxhounds coursing the hills, their baying a wild but measured and exultant music rolling through the hollows, and, tagging hopelessly along behind them, but yelping and, "ki-aiying" to split their penny- 


\section{WHERE ROLLS THE OREGON}

whistles, a little fox-terrier and a-dog, a pathetic bundle of dog that might once, far back, have been part bull, or something. But the little terrier, and his companion, the mill-ends mongrel, the latter domesticated into something hardly dog, still had enough of the wild in them to join the pack and run their little domesticated legs almost off in order to be in at the kill. "Out of unhandseled savage nature, out of terrible Druids and Berserkers, come at last Alfred and Shakespeare," says Emerson. Out of the wolf at last has come this little terrier and the mongrel; but never out of them will wholly be eradicated the savage and terrible wolf.

Uut of the wild boar, too, have come all the varieties of our domestic hogs, and just as the wild boar's progeny are born to-day with longitudinal stripes on their bodies, reverting to some striped ancestor of the far past, so a litter of prize Chester Whites, with pink spots on their cultivated faces where the wild boar's snout used to extend, hark back to the grizzled, tusked old sire of the forest in so many of their pig ways as quite to bridge the gap of their sojourn in parlor and pen.

None of our domestic animals is milder-eyed 
or of a meeker mien than the cow. She is never abject like the donkey; but centuries of gentling and giving down have made her cowlike, until she is in danger of forever losing her horns. She is not in any danger of forgetting how to use horns, however. More than once have I been chased in the evening by the cow I had driven peacefully to pasture in the morning. On one occasion I narrowly escaped with my life from the kindest of old cows, one which I had been driving to the meadows all summer. Her newborn calf was the trouble. She had hidden it among the mallows, stationed herself near by and waited for me, as a thousand years before she had waited for the wolf or the bear. Her swift and unexpected lunge was the very fury of wildness.

Little as domestication has changed the individual animal, it has changed still less the animal group - the herd, the flock, the pack. The spirit of the pack and herd spring from deep and primal needs - common fear, or hunger, or the call of kind to kind. The gregarious animal must be separated from its clan to be domesticated. Allowed to return to the herd or pack, it lapses 


\section{WHERE ROLLS THE OREGON}

promptly into the wild state; for the spirit of the herd is essentially wild.

Our Western cattle are none of them native. There is no wild native stock except the bison. Our cattle are all European, and represent centuries of careful breeding. I have never tried to trace their several lines back to the aurochs, the European bison, - if they can be traced, - but the wild blood of that anarch old must have ceased running in their veins long, long ago. Not so his spirit in them. A herd of heavy, bald-faced Herefords, just beneath their corn-fed coats, may be found as wild and dangerous as a herd of these wild buffalo.

We were trailing the "riders" of $\mathrm{P}$ Ranch across the plains to a hollow in the hills called the "Troughs," where they were to round up a lot of cattle for a branding. On the way we fell in behind a bunch of some fifty cows and yearlings which one of the riders had picked up, and, while he dashed off across the desert for a "stray," we tenderfeet drove on the herd. It was hot, and the cattle lagged, so we urged them on. All at once I noticed that the whole herd was moving with a swinging, warping gate, with switching 
tails, and heads thrown round from side to side as if every one of them were watching us. We were not near enough to see their eyes, but the rider, far across the desert, saw the movement and came cutting through the sage, shouting and waving his arms to stop us. We had pushed the driving too hard. Mutiny was spreading among the cattle, already manifest in a sullen, ugly temper that would have brought the herd charging us in another minute, had not the cowboy galloped in between us just as he did - so untamed, unafraid, and instinctively savage is the spirit of the herd.

It is this herd-spirit that the cowboy on his long cross-desert drives to the railroads most fears. The herd is like a crowd, easily led, easily excited, easily stampeded, - when it becomes a mob of frenzied beasts, past all control, like the spirit of the city "gang" at riot in the streets.

If one would know how thin is the coat of domestication worn by the tamest of animals, let him ride with the cattle across the rim-rock country of southeastern Oregon. No better chance to study the spirit of the herd could possibly be had. And in contrast to the herd, how intelligent, 


\section{I3O WHERE ROLLS THE OREGON}

controlled; almost human seems the plainsman's horse!

I share all the tenderfoot's admiration for the cowboy and his " pony." Both of them are necessary in bringing a herd of four thousand cattle through from P Ranch to Winnemucca; and of both is required a degree of daring and endurance, as well as a knowledge of the wild animal mind, that lifts their hard work into the heroic, and makes of every drive a sagebrush epic - so wonderful is the working together of man and horse, the centaur come back! So free and effective the body directed by the human intelligence that fills and rules it like a soul.

From P Ranch to Winnemucca is a seventeenday drive through a desert of rim rock and greasewood and sage, that, under the most favorable of conditions, is beset with difficulty, but which in the dry season, and with a herd even approaching four thousand, becomes an unbroken hazard. More than anything else on such a drive is feared the wild herd-spirit, the quick, black temper of the cattle, that, by one sign or another, ever threatens to break the spell of the riders' power and sweep the maddened or terrorized beasts to 


\section{THE SPIRIT OF THE HERD I3I}

destruction. The handling of the herd to keep this spirit sleeping is an anxious, and it may be a thrilling, experience.

Some time before my visit to P Ranch in the summer of 1912 , the riders had taken out a herd of four thousand steers on what proved to be one of the most difficult drives ever made to Winnemucca. For the first two days on the trail the cattle were strange to each other, having been gathered from widely different grazing grounds,

- from Double $\mathrm{O}$ and the Home Ranch, - and were somewhat clannish and restive under the driving. At the beginning of the third day signs of real trouble appeared. A shortage of water and the hot weather together began to tell on the temper of the herd.

It is early in the drive that the wild spirit seems most liable to break out, before the drive has settled to its pace and the cattle grown accustomed to the continuous and insistent authority of the riders. If they can be carried safely through the first three days, say the cattlemen, there is comparatively little danger after that.

The drive from the $\mathbf{P}$ Ranch was started under ill conditions. The first two days were safely 


\section{I32 WHERE ROLLS THE OREGON}

passed, but the third day began ominously. The line started forward at dawn, a hot early dawn, and all day long kept moving, with the sun cooking the bitter smell of the sage into the air, and with sixteen thousand hoofs kicking up a still bitterer cloud of alkali dust which inflamed eyes and nostrils and coated the very lungs of the cattle. The fierce desert thirst was upon the herd long before it reached the creek where it was to bed for the night. The heat and the dust made slow work of the driving, and it was already late when they reached the watering place, only to find it dry.

This was bad. The men were tired, but the cattle were thirsty, and Wade, the boss of the "buckaroos," pushed the herd on toward the next rim rock, hoping to get down to the plain below before the end of the slow desert twilight. Anything for the night but a dry camp!

They had hardly started on when a whole flank of the herd, suddenly breaking away as if by prearrangement, tore off through the brush. The horses were as tired as the men, and, before the chase was over, the twilight was gray in the sage, making it necessary to halt at once and camp 


\section{THE SPIRIT OF THE HERD $\quad$ I 33}

where they were. They would have to go without water.

The runaways were brought up and the herd closed in till it formed a circle nearly a mile around. This was as close as it could be drawn, for the cattle would not bed down. They wanted water more than they wanted rest. Their eyes were red, their tongues raspy with thirst. The situation was serious.

But camp was made. Two of the riders were sent back along the trail to bring up the "drags," while Wade, with his other men, circled the uneasy cattle, closing them in, quieting them, and doing everything possible to induce them to bed down.

They were thirsty; and, instead of bedding, the herd began to "growl" - a kind of stifled mutter in the throats of the cattle, low, rumbling, ominous, as when faint thunder rolls behind the hills. Every plainsman fears the growl, for it usually is a prelude to the "milling," as it proved to be now, when the whole vast herd began to stir - slowly, singly at first and without direction, till at length it moved together, round and round, a great compact circle, the multitude of clicking 


\section{WHERE ROLLS THE OREGON}

hoofs, of clashing horns and chafing sides sounding not unlike the rushing of rain across a field of corn.

Nothing could be worse for them, for it would only add to their heat and thirst. The cooler twilight was falling, but, mingling with it, rose and thickened and spread the choking dust that soon covered the cattle and shut out all but the dark wall of the herd from sight.

Slowly, evenly, swung the wall, round and round, without a break. I have never seen a milling herd and I can scarcely imagine its suppressed excitement, the waking, the stirring of four thousand wild spirits! To keep this excitement in check was the problem of Wade and his men. And the night had not yet begun.

When the two riders had brought in the drags, and the chuck-wagon had lumbered up with supper, Wade set the first watch.

Along with the wagon had come the fresh horses - one of them being Peroxide Jim, a supple, powerful, clean-limbed buckskin, a horse, I think, that had as fine and intelligent an animalface as any creature I ever saw. Wade had been saving this horse for emergency work. And why 


\section{THE SPIRIT OF THE HERD 135}

should he not have been saved fresh for just such a need as this? Are there not superior horses as well as superior men - a Peroxide Jim to complement a Wade?

The horse knew the cattle business and knew his rider perfectly; and though there was nothing like sentiment about the boss of the P Ranch riders, his faith in Peroxide Jim was complete.

The other night-horses were saddled and tied to the wheels of the wagon. It was Wade's custom to take his turn with the second watch; but, shifting his saddle to Peroxide Jim when supper was over, he rode out with the four of the first watch, who, more or less evenly spaced, were quietly circling the herd.

The night, for this part of the high desert, was unusually warm. It was close, still, and without a sky. The near, thick darkness blotted out the stars. There is usually a breeze at night over these highest rim-rock plains, that, no matter how hot the day, crowds the cattle together for warmth. To-night not a breath stirred the sage as Wade wound in and out among the bushes, the hot dust stinging his eyes and caking rough on his skin. 


\section{WHERE ROLLS THE OREGON}

Round and round rode the riders; round and round moved the weaving, shifting forms of the cattle, out of the dark and into the dark, a gray spectral line like a procession of ghosts, or some morris dance of the desert's sheeted dead. But it was not a line, it was a sea of forms; not a procession, but the even surging of a maelstrom of hoofs a mile around.

Wade galloped out on the plain for a breath of air and a look at the sky. If it would only rain! A quick, cold rain would quiet them; but there was no feel of rain in the darkness, no smell of it on the air; only the powdery taste of the bitter sage.

The desert, where the herd was camped, was one of the highest of a series of tablelands, or benches; it lay as level as a floor, rimmed by sheer rock, from which there was a drop to the bench of sage below. The herd when overtaken by the dusk had been headed for a pass descending to the next lower bench, but was now halted within a mile of the rim rock on the east, where there was a perpendicular fall of about three hundred feet.

It was the last place an experienced plainsman 


\section{THE SPIRIT OF THE HERD I 37}

would have chosen for a camp; and every time Wade circled the herd, and came in between the cattle and the rim, he felt the nearness of the precipice. The darkness helped to bring it near. The height of his horse brought it near - he seemed to look down from his saddle over it, into its dark depths. The herd in its milling was surely warping slowly in the direction of the rim. But this must be all fancy - the trick of the dark and of nerves, if a plainsman has nerves.

At twelve o'clock the first guard came in and woke the second squad. Wade had been in the saddle since dawn, but as this second was his regular watch he stayed in the saddle. More than that, his trained ear had timed the milling hoofs. The movement of the herd had quickened.

If now he could keep them going, and could prevent their taking any sudden fright! They must not stop until they stopped from utter weariness. Safety lay in their continued motion. So the fresh riders flanked them closely, paced them, and urged them quietly on. They must be kept milling and they must be kept from fright.

In the taut silence of the stirless desert night, with the tension of the herd at the snapping-point, 


\section{I38 WHERE ROLLS THE OREGON}

any quick, unwonted sight or sound would stampede them. The sneezing of a horse, the flare of a match, would be enough to send the whole four thousand headlong - blind, frenzied, trampling - till spent and scattered over the plain.

And so, as he rode, Wade began to sing. The rider ahead of him took up the air and passed it on until, above the stepping stir of the hoofs rose the faint voices of the men, and all the herd was bound about by the slow plaintive measures of some old song. It was not to soothe their savage breasts that the riders sang to the cattle, but rather to preëmpt the dreaded silence, to relieve the tension, and so to prevent the shock of any sudden startling noise.

So they sang and rode and the night wore on to one o'clock, when Wade, coming up on the rim-rock side, felt a cool breeze fan his face, and caught a breath of fresh, moist wind with the taste of water in it.

He checked his horse instantly, listening as the wind swept past him over the cattle. But they must already have smelled it, for they had ceased their milling, the whole herd standing motionless, the indistinct forms close to him in the dark show- 


\section{THE SPIRIT OF THE HERD I 39}

ing their bald faces lifted to drink the sweet wet breath that came over the rim. Then they started on again, but faster, and with a rumbling now from their hoarse throats that tightened Wade's grip on the reins.

The sound seemed to come out of the earth, a low, rumbling mumble, as dark as the night and as wide as the plain, a thick, inarticulate bellow that stood every rider stiff in his stirrups.

But how dark was the night, and how thick the smother of dust ! Nothing could be seen; and the hoarse, choking bellow of the herd, as thick as the dark and the dust, made all other sounds impossible to hear.

Then the breeze caught the dust and carried it back from the gray-coated, ghostly shapes, and Wade saw that the animals were still moving in a circle. He must keep them going. He touched his horse to ride on with them, when across the black sky flashed a vivid streak of lightning.

There was a snort from the steers, a quick clap of horns and hoofs from far within the herd, a tremor of the plain, a roar, a surging mass - and Wade was riding the flank of a wild stampede. Before him, behind him, beside him, pressing hard 


\section{WHERE ROLLS THE OREGON}

upon his horse, galloped the frenzied steers, and beyond them a multitude borne on, and bearing him on, by the heave of the galloping herd.

Wade was riding for his life. He knew it. His horse knew it. He was riding to turn the herd, too, back from the rim, as the horse also knew. The cattle were after water - water-mad - ready to go over the precipice to get it, carrying horse and rider with them. Wade was the only rider between the herd and the rim. It was black as death. He could see nothing in the sage, could scarcely discern the pounding, panting shadows at his side. He knew that he was being borne toward the rim, how fast he could not tell, but he knew by the swish of the brush against his tapaderos and the plunging of the horse that the ground was growing stonier, that they were nearing the rocks.

To outrun the herd was his only chance for life. If he could come up with the leaders he might not only escape, but even stand a chance of heading them off upon the plain and saving the herd. There were cattle still ahead of him; how many, what part of them all, he could not make out in the dark. But the horse knew. The 


\section{THE SPIRIT OF THE HERD I4I}

reins hung on his straight neck, where his rider had dropped them, as, yelling and firing over the wild herd, he had given this horse the race to win, to lose.

They were riding the rim. Close on their left bore down the flank of the herd, and on their right, under their very feet, was a precipice, so close that they felt its blackness - its three hundred feet of fall!

Suddenly they veered and went high in the air, as a steer plunged headlong into a draw almost beneath their feet. They cleared the narrow ravine, landed on bare rock and reeled on.

A piercing, half-human bawl of terror told where one of the animals had been crowded over. Would the next leap carry them after him? Then Wade found himself racing neck and neck with a big white steer, which the horse, with marvelous instinct, seemed to pick out from a bunch, and to cling to, forcing him gradually ahead, till, cutting him free from the bunch entirely, he bore him off into the swishing sage.

The steers coming on close behind followed their leader, and in, after them, swung others. The tide was turning from the rim. More and 
142 WHERE ROLLS THE OREGON

more were veering, and within a short time the whole herd, bearing off from the cliffs, was pounding over the open plains.

Whose race was it? It was Peroxide Jim's, according to Wade, for not by word or by touch of hand or knee had the horse been directed in the run. From the flash of the lightning the horse had taken the bit, had covered an indescribably perilous path at top speed, had outrun the herd and turned it from the edge of the rim rock, without a false step or a tremor of fear.

Bred on the desert, broken at the round-up, trained to think steer as his rider thinks it, the horse knew as swiftly, as clearly as his rider, the work before him. And he knew how to do it, or could see in the dark how to do it, far better than his rider. But that he kept himself from fright, that none of the wild herd-madness passed into him, is a thing for great wonder. He was as thirsty as any of the herd; he knew his own peril, perhaps, as none of the herd had ever known anything; and yet, such coolness, courage, wisdom, and power!

Or was it only training? More intimate association with the man on his back, and so, a further 


\section{THE SPIRIT OF THE HERD I 43}

remove from the wild thing which domestication does not seem to touch? Or was it all suggestion, the superior intelligence above riding, not the flesh, but the spirit? 



\section{VII}

THE BUTTERFLIES OF MOUNT HOOD 



\section{VII}

\section{THE BUTTERFLIES OF MOUNT HOOD}

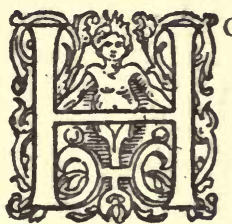

ow often one becomes the victim of one's special interests! I climbed to the peak of Hood, looked down upon Oregon and into her neighbor States, saw Shasta far off to the south, and Rainier far off to the north, and then descended, thinking and wondering more about a flock of little butterflies that were wavering about the summit than about the overpowering panorama of river and plain and mountainrange that had been spread so far beneath me. Or was I the victim, rather, of my inheritance? Was it because I happened to be born, not on a mountain-peak eleven thousand two hundred and twenty-five feet above the sea, but in a sandy field at sea-level? I was born in a field bordering a meadow whose grasses ran soon into sedges and then into the reeds of a river that flowed into the bay; and I found myself on the summit of Hood 


\section{WHERE ROLLS THE OREGON}

dazed and almost incapable of great emotion. So I watched the butterflies.

Or was it that I lacked training? Might one not need to climb Hood many times for the eyes to grow used to seeing and the soul to feeling such unwonted vastness of expanse, such unaccustomed and overwhelming depths? I have tried a hundred times to recall the emotion of my first moment on the summit, and either I had none, or what I had was an utter weariness of body and a depression of spirit due to a sense of my inability to meet the moment emotionally. I felt in spirit as I felt in body, the body perhaps having much to do with the spirit.

We started before seven o'clock from CloudCap Inn and reached the summit a little past noon, a steady half-day of climb, climb, climb, the last four thousand feet zigzagging across the steep flank of a glacier, the last eighteen hundred feet by the help of a rope from the summit up the sheer ice wall to the peak. I reached the rim of the crater exhausted. Two other strong men of the party came over the rim sick. We had a professional mountain-climber with us who was fresh from the Canadian Rockies and who had come to the 
Rockies directly from the Swiss Alps. $\mathrm{He}$ and the guide arrived at the top physically capable of looking at the scene; but the guide did not care to look, climbing Hood being a business with him; and the professional climber (whose business was breaking records) was too disgusted at the wretched time he had made, tied up to us, to look at anything, and was for starting down at once, alone if the guide would let him, to try yet for a record round-trip. So here we were undone, indifferent, disgusted, while the kingdoms of this world and the glory of them lay spread out beneath us - and flitting round about us a host of little butterflies.

The day was clear and cool, with a stiff wind blowing across the summit that made our teeth chatter and sent us skulking behind the lumps of slag to get out of its way. Long before we reached the top heavy gaseous fumes began to pour down upon us as the draft drew over the rim of the crater. The wind seemed to clear them from the immediate top, but, looking down into the great pit, we could see a rising cloud of steam that must have carried them in its vaporous folds up out of the heated depths where the ancient 


\section{I50 WHERE ROLLS THE OREGON}

fires were still smouldering. Hood is a burned-out volcano, as is every cone in the Cascade Range, whose fires were blazing throughout the middle epochs of the Tertiary Period, whose lava-flows now spread as sage plains all over eastern Oregon where the stratified ash and tuff lie three to four thousand feet deep. The Oligocene epochs of those flaming fires passed into the Miocene, the Miocene into the Pliocene, when the Tertiary Period gave place to the Quaternary with its Pleistocene epoch of Glacial and Interglacial stages, which, in turn, passed into our present epoch; and still the walls of Hood retain their heat; and still the vapors rise and pour through the rifted rim of the crater down over those glacial snows that lie unmelted on the summit.

The topmost point of Hood is a jagged piece of yellow igneous rock or slag, soft, sulphurous, with the smell of the volcanic fires still strong upon it. Originally a part of the crater wall, it is now but a weathered fragment poised on a pinnacle left by the caving of the rest of the rim into the cavity of the crater. The summit is thus a point, an apex, one of the few high peaks of the world upon which you can stand, and, without 


\section{BUTTERFLIES OF MT. HOOD I5I}

moving from your position, box the compass with the landscape, the whole world lying directly beneath you and rounding out to an unbroken horizon that girdles the globe.

And away up here above the world, here over the eternal snows, here in the fumes of old volcanic fires, hovered a host of black and red butterflies. It was an amazing sight. I was prepared for hailstones and coals of fire, for seismic shocks and slides and booming avalanches, but not for butterflies.

Cloud Cap Inn, our starting-point that morning, is on the edge of the tree-line. We passed immediately into the Alpine zone on leaving the Inn, a few flattened, twisted pines accompanying us for a distance, a few Alpine-Arctic flowers going on with us almost to the stony shoulder of Barrett's Spur, some four thousand feet from the summit. But here all life seemed to stop. The Spur rises between the two great glaciers of this side of the mountain, separating them at right angles. It is a high pile of broken rock, so utterly devoid of soil that life could scarcely find a footing here, were it able to climb so high; but the white lupine, the flat pussypaws, the low purple 


\section{I52 WHERE ROLLS THE OREGON}

heather, and the purple matted beard-tongue could not reach the crest of the Spur. The beard-tongue outclimbed the others. It was the last living thing that we saw until we reached the summit, except some flies that were sunning themselves at Tieup Rock, nearly a thousand feet above the Spur. The rapid dwarfing of the beard-tongue as we ascended was eloquent of the reach and grip of life. When the little clusters or colonies could no longer hold on in the open, they took to hiding behind the pieces of rock, the last of them seeking the shelter of the north sides, where, huddled back from the blight of the noonday sun and the sweep of the blasting winds, they found a slightly moister soil and a temperature a few degrees more equable, the meager means of a last desperate effort for a highest-up. Then the small shadows failed, and we climbed on alone.

It is an impressive thing to leave all life beneath you, to pass from zone to zone witnessing the changes in the forms and the modes of living things as you ascend, but still with life about you, until you find yourself in the presence of an allpervading death. The very sun has changed. You have come within the veil, up through the screen 


\section{BUTTERFLIES OF MT. HOOD 153}

that breaks the fierce light into the prismatic colors of life, and the white rays now blind your eyes and blister the skin of your face and hands. The air is lighter in your lungs; the cold is keen and constant; the look of all things strange and unfriendly.

This leaving of life is so real an experience, as the climber watches the shapeless, diminishing trees, the vanishing ground squirrels, and the last flattened flowers, dwarfed to nothing but root and blossom before they are blotted out, that he can scarcely get up to Barrett's Spur without feeling the presence of death, a consciousness deepened from here on by the extreme narrowness of the footing and the utter withdrawal of space from about him, space that in the crowded valleys of life he had been used to leaning upon.

From the Spur to Tie-up Rock our path was a narrow back that divided the two glaciers. At Tieup Rock we were belted and fastened together and roped to the guide, who now led us out upon the steep snows that reached up and up to the summit, towering, as it seemed, almost straight overhead.

The climb was without accident, and as moun- 


\section{WHERE ROLLS THE OREGON}

taineering goes, according to the professional climber, who was last in the string, beautiful enough, but rather tame.

For all of that there was one place in the climb that gave me a shudder, and one moment of thrill, when even the professional climber turned pale. We had ascended perhaps a thousand feet above Tie-up Rock when we came to a crevasse across the glacier. It was a yawning gap, as clean as some awful knife-wound through the blue ice, and, illumined by the sunlight, which at that moment shot straight down its unearthly walls, revealed, as not even the heights above us could, the grip of the cold, the depth of the death that lies upon the world. And ten or twelve feet down, taut from solid wall to wall across the crevasse, stretched a stout hemp rope - a human thing frozen into this eternal pit! The sight of it, so unexpected, mysterious, and horribly significant, was shocking. But it proved to be only the rope which the guides had left hanging from the summit the summer before. It had been buried to this depth during the winter, and with slack enough at this place to stretch without snapping when the ice split and the crevasse opened across the glacier. 


\section{BUTTERFLIES OF MT. HOOD I 55}

Working round the crevasse, we kept on till we reached the new rope dropped down to us eighteen hundred feet from the peak. Here we stuck our pikes into the snow, breathed ourselves for a minute, and laid hold on the rope. As we did so, a piece of rock, about the size of a large waterpail, was dislodged from the summit and started down the sheer slope straight at us. It was dropping down the steps cut by the last climbers to reach the peak, a path as straight to us as the rope could fall. Gripping the rope we swung to one side, watching the wild thing as it came plunging, bounding at us with incredible speed, ready to dodge should it fly at our heads. It was a fearful quarter-minute. Down it came, straight at its mark, leaping faster, farther, higher with every spring from the snow. Down straight at us it tore, struck just in front of us, ripped past with a wicked whiz, hit a hundred feet below us, sprang madly into the air, and, like a bolt, was gone.

Then the real work of the climb began, and to it was added this new alarm of rolling rocks. I had grown by this time quite familiar with the fear of falling, and had ceased to mind it; but I 


\section{I56 WHERE ROLLS THE OREGON}

had had no practice in dodging rocks. To be sandbagged on the level is a risk that I have been indifferent to these many years; to be knocked on the head by a ricochetting rock, however, with ten thousand feet to fall, disturbed me considerably. But the guide thought nothing of it. The incident apparently left no impression upon him. He was used to flying rocks. He was used to this particular climb, too. How easily, surely he moved! If I had my life to live over again, I thought, I would be a climber of mountain-peaks - so superior did he seem! So admirable is any sort of mastery! And how carefully he moved! kicking the niche for his toe, or cutting the step into the ice with all deliberateness, giving me time to jack my feet up and fix them where his had been. Still the rope that fastened me to him was continually taut; I was loaded with lead. Then the man behind me groaned and stopped. I reached back, took his camera - and it was lead, solid lead. Then the man behind him groaned and stopped, seized with nausea. But the line crawled on up, up, up, through a gateway of snow to the bare rock of the summit.

The experience was worth while; and the view, 


\section{BUTTERFLIES OF MT. HOOD I 57}

though too vast, too complete, too sublime for the heart to hold, was worth the climb, and more. I doubt if a few thousand extra feet - the height of Mont Blanc or Denali - could add anything to the prospect from Hood. The consciousness of such heights might deepen one's sense of awe and terror, but could only blur the earth below and leave one cut off as a thing of clay among the clouds.

So I felt even on the top of Hood until I saw the butterflies. And what a relief, what a surprise to see Vanessa californica flitting about the peak of Hood! I could have fallen off for astonishment! I had not seen the butterflies at first. Not until the keen, cutting wind drove us to shelter behind the rocks did I notice the tiny creatures winging past.

We were sitting where we could look into the crater on the one side, and where, directly beneath us, we could see clear down the wall with the rope, to the glacier and the trail over which we had come. At our feet was a small gully, a kind of flue in the crater-wall. The draft pulled hard in every direction among the gaps and cuts of the rocks, but hardest up this flue or chimney. The butterflies seemed to be ascending the mountain, 


\section{I $5^{8}$ WHERE ROLLS THE OREGON}

coming over the summit by way of the flue, using the draft, as we had used the rope.

But they were not ascending the mountain; they were merely flitting about over the summit, as if the height were home to them. When they had come - how long they had been therehow long they stayed - I should like to know. Why they had come and what they were doing, however, I think I do know, though it may seem quite past belief at such a height, amid the eternal snows, with noxious fumes filling the air, and a wind blowing across the peak that, as soon as the sun was set, would stop the beat of a stouter heart than a butterfly's. The fragile creatures had sailed to the summit of Hood to play; and here they were at their sport as truly as children may be seen at theirs in the school-yard.

It was their regular passing at a certain distance from me, and their disappearance in a certain direction, that aroused my curiosity. And the number of them! and that all were coming up, none going down! - all of them appearing to shoot up through the little gully or cut between the rocks and to bear off to the right over the crater! What did it mean? 


\section{BUTTERFLIES OF MT. HOOD I 59}

Scrambling to the top of the rock behind which I was resting, and where I could get a survey all around, I saw that the peak was alive with butterflies; that they were flying past my head, and off over the point out of sight around the walls, to reappear far down in the crater, across which they were cutting to my side where, caught in the draft, they were pulled up the flue, up and past my head again, off over the point out of sight to reappear again, far down below, for another turn with their toboggan on the slide of the draft that drew up past us over the summit.

Not all of them were in the game; I caught two as they sunned themselves on the rocks; but that all had played, or would join the fun, and that all had come up for that purpose, I have no doubt.

Yet my reader may have doubts. Then let him explain the case. We are quite likely to overlook the extent and seriousness of wild animal play; not so much overlook it, perhaps, as fail to see it, so self-conscious and on guard is all wild life in the presence of a human watcher. Self-abandonment is a necessary condition of real play, and 


\section{WHERE ROLLS THE OREGON}

among the wild animals unconsciousness even of observation seems a necessity, which accounts largely for our fleeting and infrequent glimpses of this side of wild life, so seldom can we get close enough to watch the play of a wild creature without exciting alarm. But wild life is not all watchfulness and fear; there is a time for play in the soberest, somberest of wild lives. The animals play joyously, keenly, seriously, desperately even, as college boys play desperately at football, and old men seriously at solitaire; for killing time is a serious business, and killing your rival in football is certainly desperate enough.

I have watched a great ungainly hippopotamus solemnly trying to kill time by cuffing a croquet ball back and forth from one end of his cage to the other. His keeper told me, that, without the plaything, the caged giant would fret and worry himself to death. It was his game of solitaire. This play of the butterflies was nothing if not joyous, yet there was something fearful and desperate in the choice of the peak for the game.

In all their games of rivalry, which seem to be mimic warfare, the animals are as serious as humans, and, forgetting the fun, often fall to fighting. 


\section{BUTTERFLIES OF MT. HOOD I6I}

Only this morning, the whole flock of chickens in the hen-yard started suddenly on the wild flap to see which would beat to the back fence, and wound up at the "tape" in a free fight, two of the cockerels tearing the feathers from each other in a desperate set-to.

You have seen puppies fall out in the same human fashion, and kittens also, and other folk as well. I have seen a game of wood tag among friendly gray squirrels come to a finish in a free fight. As the crows pass over during the winter afternoon you will notice their play, - racing each other through the air, diving, swooping, cawing in their fun, when, suddenly, some one's temper snaps, and there is a general mix-up in the air. I watched the butterflies for such evidences of temper and individuality, but saw nothing like recognition of each other among them, no communication of any sort, no initiative except as one would turn aside from his play to light for a sip of snow or a moment of rest in the sun. Yet I have seen angry butterflies, one mourning-cloak (Vanessa antiopa) putting a whole stumpful to flight by dashing in among them. Here on the peak there must have been some 


\section{WHERE ROLLS THE OREGON}

flock-consciousness, sight or scent or other kind of communication. Certain butterflies flock and migrate together with as evident a plan and agreement as the flocking birds have; but for the most part they are solitary creatures. Did they come singly to the summit of Hood, without agreement and without purpose, each one flying up and up, in a blind attempt to scale the opposing wall and so reaching the top? Then why did they not pass over and down? Why did they stay? Whatever be the right guess, it was surely not for food that they congregated here.

I think they came to play, and that they came, perhaps, " by foreward and by composicioun." For the love of play is much more compelling in animal life than we imagine. The lack of laughter alone distinguishes animal play from ours. We climbed the peak for play - the guide alone for money; and I don't remember that one of us so much as smiled during the time we spent on the summit. How did we differ from the butterflies? The animals have no sense of humor. From the highest to the lowest they show the keenest joy in sport; but they cannot laugh; theirs is mirthless play. I once saw, however, what I took 


\section{BUTTERFLIES OF MT. HOOD $16_{3}$}

for a twinkle of merriment in an elephant's eye. It was at Barnum's Circus several years ago. I remember the scene well. The keeper had just set down for one of the elephants a bucket of water, which a perspiring and important youth had brought in. The big beast sucked the water quietly up - the whole of it - swung gently around to thank the perspiring boy, then soused him, the whole bucketful! Everybody roared, and one of the elephants joined in with trumpetings, so high and jolly was the joke.

The elephant that played the trick looked solemn enough, except for a twitch at the lips and a glint in the eye. There is something of a smile about every elephant's lips, to be sure, and fun is so contagious that one should hesitate to say that he saw the elephant laugh. But if that elephant did not laugh, it was not his fault.

From the elephant to the infusorian, the microscopic animal of a single cell, is a far call - to the extreme opposite end of the animal kingdom, worlds apart. Yet I have seen Paramacium. caudatum at play, in a drop of water under a compound microscope, as I have seen elephants. 


\section{WHERE ROLLS THE OREGON}

at play in their big bathtub at the Zoölogical Gardens.

Place a drop of stagnant water under your lens and watch these atoms of life for yourself. Invisible to the naked eye, they are easily followed on the slide as they skate and whirl and chase each other to the boundaries of their playground and back again, first one of them "it," then another. They stop to eat; they slow up to divide their single-celled bodies into two cells, the two cells now two living creatures, where, a moment before, there was but one, each swimming off immediately to feed and play and multiply.

Play seems to be as natural and as necessary to the wild animals as it is to the human. Like us, the animals play hardest while young, but as some human children never outgrow their youth and love of sport, so there are old animals that never grow too fat, nor too stiff, nor too stupid to play.

The condition of the body has a great deal to do with the state of the spirit. The sleek, lithe otter could not possibly grow fat. He keeps in trim because he cannot help it, perhaps; but, however that may be, he is a very boy for play, 


\section{BUTTERFLIES OF MT. HOOD 165}

and even goes so far as to build himself a slide, or chute, for the fun of diving down it into the water.

That is as much as we children used to do, and more, for we had, ready-made for us, Grandfather's two big slanting cellar-doors, down which we slid, and slid, and slid, till the wood was scoured all white and slippery with the sliding. The otter loves to slide. Up he climbs on the bank, then down he goes splash into the stream. Up he climbs, down he goes - time after time, day after day. A writer in one of our recent magazines tells of an otter in the New York Zoölogical Park that dived about his tank balancing a stone on the top of his head.

How much of a necessity to the otter is his play, one would like to know - what he would give up for it, and how he would fare, deprived of it. In the case of Pups, my neighbor's beautiful young collie, play seems more needful than food. There are no children, no one, to play with him there, so that the sight of my small boys sets him almost frantic.

His efforts to induce a hen or rooster to play with him are pathetic. The hen cannot under- 


\section{I66 WHERE ROLLS THE OREGON}

stand. She has n't a particle of play in her anyhow; but Pups cannot get that through his head. He runs rapidly round her, drops flat on all fours, swings his tail, cocks his ears, looks appealingly and barks a few little cackle-barks, as nearly hen-like as he can make them, then dashes off and whirls back - while the hen picks up another bug. She never sees Pups. The old white coon cat is better; but she is usually up the miff-tree. Pups steps on her, knocks her over, or otherwise offends, especially when he tags her out into the fields and spoils her hunting. Won't the Society for the Prevention of Cruelty to Animals send out some child or puppy to play with Pups of a Saturday? - lest Pups follow his predecessor Rex to an early grave from gout, induced by all food and no play.

I doubt if among the lower animals play holds any such prominent place as with the dog and the keen-witted, intelligent otter. To catch any of them at play is a rare experience, and to have a chance to play with them is infinitely rarer. The other day I was told by a friend of a fox on one of the golf-links of Boston that tried 


\section{BUTTERFLIES OF MT. HOOD 167}

to play golf, or rather, tag. The golfer and his small son were knocking the ball back and forth about the green, it being too near dusk to play, when the boy called his father's attention to some creature watching them from the edge of a grove. It was a fox. Just then the ball was sent in the direction of Reynard, who ran out on the green, caught it up, and cut for the woods with the golfers after him. He dropped the ball, ran on, and stopped to watch the players again. Again they knocked the ball toward him, when he ran after it and scampered with it for the trees, the two golfers yelling at him and chasing him till he dropped it. Then they took an old ball, drove it far before them across the path of the fox, who once more seized it, and with the human playmates at his heels got away successfully, the ball in his teeth, amidst the trees. $\mathrm{He}$ was perhaps a young fox who, like Pups, was dying for a little play.

One of our naturalists describes the game of "follow my leader" as he watched it played by a school of minnows - a most unusual record, but not at all hard to believe, for I saw only recently, from the bridge in the Boston Public 


\section{I68 WHERE ROLLS THE OREGON}

Garden, a school of goldfish playing at something very much like it.

This observer was lying stretched out upon an old bridge watching the minnows through a crack between the planks, when he saw one leap out of the water over a small twig floating at the surface. Instantly another minnow broke the water, followed by another and another, the whole school, as so many sheep, or so many children, following the leader over the twig.

The love of play seems to spring from one of the elemental needs of animal life, and the games of us human children seem to have been played before the dry land was, when there were only water-babies in the world, for certainly the fish never learned "follow my leader" from us. Nor did my young bees their game of "prisoners' base," which they play almost every summer noontime in front of the hives. And what is the game the flies play about the cord of the droplight in the center of the kitchen ceiling?

And what was the game the butterflies were playing over the peak of Hood? And how came they there? And whither went they when the sun sank that night, and the wind swung 


\section{BUTTERFLIES OF MT. HOOD 169}

hard to the north, and the gods of the storms met on the summit?

We saw the clouds gathering below us as we started down. On the glacier walls we met the cold winds climbing up and heard their talk of storm until we came within the shelter of the trees about the Inn. During the night I woke to listen for the sound of feet on the mountain, but none bent the pines outside my window, nor swayed the wide wooded slopes that stretched away to the orchards and the valleys below. Near morning a slow rain began to fall. Was this the talk that we had heard along the heights? This the meeting of those forces flying past us toward the summit? Then through the small stepping of the rain I caught far off a mightier tread, a faint concord of crash and roar - or felt it in the very frame of things, as when an organ fills the deep dim places of the church with trembling, and no note is heard. Hurrying out, I saw the rain slanting down the cañon, the dull sky darkening behind the peak, while all about the summit smoked the gray smother of storm. Suddenly the smoke lifted, filled, poured over and down till, caught in some mighty draft, the cloud 


\section{I70 WHERE ROLLS'THE OREGON}

broke and swept swirling back to the pinnacle in a million flying shreds, where, rounding again into billows, it was torn into streaming sheets that whipped far down the precipitous walls, winding the summit instantly in another shroud of snow.

Gale and snow-cloud this morning, where, yesterday, it was butterflies that were playing over the lofty crater of Mount Hood. 


\section{VIII}

\section{THE ROCKS FOR THE CONIES}





\section{VIII}

\section{THE ROCKS FOR THE CONIES}

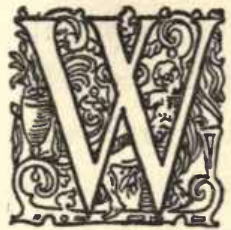

E were hunting for mountain sheep in the wildest peaks of the Wallowa range, and incidentally had tried the fishing in the Imnaha. Such trout! But it is so in all the Oregon rivers. We were after mountain sheep, not trout, and we came off with a cony. It was not the first time. Many an expedition has so turned out; many of mine, I mean, conies for sheep, the feeble folk for the strong rangers of the high hills.

Life is not a matter of size, except, perhaps, to the hunter. To the naturalist and lover of nature, life is a matter of kind, the cony after his kind being as interesting as the wild goat after his kind, or the stork after her kind. I doubt, indeed, if ever the mystery and wonder of animal life impressed me more than while I sat by the cony slide on a peak above the clouds asking the little 


\section{WHERE ROLLS THE OREGON}

creature why and why! The geographical distribution of land animals, their successive migrations back and forth between the continents during the geological ages, is a story to stir the slowest imagination; yet no single record of these fossiled wanderings to be read in the rocks ever stirred me more than did the sight of the live cony making a home for himself in the narrow limits of his rock-slide in the rifts of the rent and blasted peaks of the Wallowas.

From the gorge of the wild Imnaha we had climbed up and up to the blade-like divide that runs between the head waters of the Big Sheep and Little Sheep Creeks on one side, and the windings of the Imnaha on the other, when our guide and our mammal-collector left us and rode on ahead. They soon struck an old mining-trail around the flank of a peak, and, winding about into this, they shortly disappeared. It was near the end of a hard day's travel, and as our indefatigable collector often took such sudden turns, I thought little of it. But that night the two came straggling late into camp with a cony, or "pika," the "little chief," or "crying," hare. This was what they had gone off in such haste for, making 


\section{THE ROCKS FOR THE CONIES 175}

a long détour to a certain rock-slide on the pass known to our young guide.

The cony is not an animal familiar to many persons. Except naturalists, few climbers who have eyes or ears for so shy, so tiny and rare a creature, and one so difficult to see, ever get into the high altitudes of the cony country. But our guide, who had been a sheep-herder and camptender in the mountains, was an exceptionally keen observer. In crossing this part of the pass the summer before he had heard and seen a peculiar little animal about the size and shape of a guinea-pig among the broken rocks of one of the slides. To this rock-slide he had taken the collector, and they had come off with one of the conies, while I, meantime, was trying to keep up with Maud and Barney, the pack-mules, descending the other side of the pass, and missing with them an experience that only a few mountainpeaks in the world could give me.

I was undone when the two men with the cony came into camp. To have been so near and then, in the company of those clownish mules, to have passed stupidly by! We had descended to Aneroid Lake for camp. Our course from here led 


\section{WHERE ROLLS THE OREGON}

down a plunging stairway to Wallowa Lake with never a hope for another cony slide on the trail. We were below the peaks. It was necessary, too, that we push forward. Not another day was to be had! Our time was up; and besides, there was nothing left to eat but sour-dough bread and condensed milk. This was too true. And my companions imagined that the thought of an extra day on sour-dough bread would cure me of my conies. A few days more of it would have cured me of everything. A particularly good fellow was our cook, one of the State's best game wardens; all of which applies only remotely to his bread. It was not necessary for me to live. It is not necessary for anybody to live. But it was necessary for me to see a live cony, though I ate more of Leffel's sour-dough bread to pay for it. One may pay too dearly for life. The price on conies, however, is never marked down.

I said nothing that night. Early the next morning one of the men reported the hobbled horses away off in the meadows at the head of the lake; and while they were being rounded up and the kit packed, I left camp unobserved, struck the upward trail and made for the peak of the cony slide. 


\section{THE ROCKS FOR THE CONIES 177}

The sun was high when I found myself slipping and sliding along the sharp slopes in sight of the great rock-heap. It was ten o'clock. No wind was moving, no sound or cry of any kind about the slide, no sign of life anywhere.

This must be the place, however. I had passed it at some distance the night before; and here were footprints leading down the bare slope up which I was scrambling. This was the slide, but who would ever have paused here before this heap of broken rock, expecting to see any living thing in it?

The slide was of cracked and splintered chunks that had broken off of the peak above and filled a wash or gully on the side, just as bricks might fall from a chimney and fill the length of a valley on the roof. Stunted trees grew at the base of the slide, and up the side some scraggly grass and a few snow-line flowers, squat alpine sorts, blooming bravely along the edges of the melting snow-banks.

This was new hunting for me. I crept round the crumbling slope and down to the border of the slide, where I stood trying to make myself believe that animal life of any kind, larger thar some of the boreal mice, could climb to this 


\section{I78 WHERE ROLLS THE OREGON}

height and here make a home. It was impossible that this barren, blasted pile from the peak could furnish shelter and food enough to keep the fires of any warm-blooded life burning throughout a winter! This was the ridge-pole of the world. A wilder, barrener, more desolate land of crags and peaks could hardly be found.

But here it was they told me they had shot the cony, and had seen at least one other besides it. So I sat down to watch, without faith; for if any creature could live here, what possible reason might there be for his electing so to do.

I was on the roof of creation, looking out and down, the sense of space tingling strangely in my finger-tips, the pull of the swinging world as real in my feet as the thrill of the thin air in my lungs. How such altitudes quicken and exaggerate the senses, the nerves and skin, even one's very hairs! I could feel the individual hairs on the back of my hands catch and transmit the messages of space, as the wires on the Cape Race Station catch theirs out of the spaces above the sea. As I sat looking out over the wild scene, a great dark hawk wheeled into distant sight toward Eagle Cap Mountain; far below me flapped a band 


\section{THE ROCKS FOR THE CONIES}

of ravens; and down, down, immeasurably far down beneath the ravens, glistened the small winding waters of the Imnaha. But it was the peaks, the scarped, sheer-shouldered peaks, stark, black, desolate, standing so close about me, that smote me with awe and a kind of lonely terror. I could stay while the sun was high. How could anything alive stay longer - through a night through a long winter of nights in this slide on the summit?

For several feet each side of the broken rock grew spears of wiry grass about six inches high, together with a few stunted flowers, - pussy'spaws, alpine phlox, beard-tongue, saxifrage, and a low single daisy. Farther down the sides of the ravine crept low, twisted pines - mere mats of trees, prostrate, distorted forms that had clambered and clung in narrow, ascending tongues up and up until they could get no higher hold on the blasted slopes.

And here above the reach of these grim, persistent pines, here in the slide rock where only a few stunted growths and arctic-alpine flowers come into brief bloom through the snow, they had told me lived the cony. 
180 WHERE ROLLS THE OREGON

I sat down on the edge of the slide to rest, feeling that I had had my labor for my pains infinitely more than that, the fierce and fearful glory of the heights - but not a cony. There could be no excuse for life up here. There are living forms in the uttermost depths of the sea, as if thrust down by the weight of water; men in their senses dwell far in the Arctic ice, and even go out into the sagebrush desert to make a home, impelled by I know not what. Strange, unaccountable shifts these, yet not so unaccountable as the choice of such a rock-slide as this for a dwelling. For this is the deliberate choice of a race. Only at these heights do the conies dwell, only in such slides of broken rock. As for the stork, the fir trees are her house. The high hills are a refuge for the wild goats; and the rocks for the conies. But this particular slide, while not so lofty as some among the Colorado peaks, was unusually bleak and barren, I am sure. There was almost no fodder in sight, nothing upon which a cony could live long, to say nothing of a colony of conies.

Could this be the place? I must make sure before settling down to the watch, for when in 


\section{THE ROCKS FOR THE CONIES I 81}

all my days would this chance come again? And how soon would they'put a posse on my trail to fetch me back to camp?

Out in the middle of the slide was a pointed pile of rocks with a certain ordered look about them, as if they had been heaped up there by other hands than those that hurled them down from the peak. Going out, I examined them closely and found the bloody print of a little bare paw on the face of one of them. On another rock was the bluish spit of a lead shot. The right place surely. Here they had killed the specimen brought into camp. I went back to my seat content now to watch until they sent for me. The camp must wait on this cony.

I had been watching for perhaps half an hour, when from somewhere, in the rock-slide I hoped, though I could not tell, there sounded a shrill, bleating whistle, not unlike that of the mountain ground squirrel's, or the marmot's, yet more tremulous and not so piercing, a trembling, ventriloquial, uncentered sound that $I$ had never heard before.

I held my breath, the better to catch the cry. Again it sounded - up or down, this side or that 
182 WHERE ROLLS THE OREGON

of the slide, I could not tell. Again and again, plaintive, whimpering, but pure and clear! I gave over my ears and, looking hard at the slide, my eyes fixed nowhere, I watched for motion. Presently, straight in front of me, a little gray form crept over a slab, stopped on all fours, and whistled, waited for a moment listening, then disappeared. The cony!

Gone? I did n't know. I did n't care. I had seen him; and that was almost more than I could believe. The moment was full, and in it the thing was done. What thing, you ask? Why, my becoming a cony, and with him now a dweller in the rock-slides of the black and bitter peaks. I have widened my range by that experience, added to my habitat; become one of the Boreal animal forms that push southward on these heights far into my Sonoran zone.

But he had not gone. Keeping as still as the stones, I waited. Presently the plaintive, bleating whistle sounded again from anywhere in the slide. I tried to find the hole into which the cony had disappeared; but the moment my eyes were taken from any spot, it was impossible to pick it out again. The rocks were rough, rusty chunks, two 


\section{THE ROCKS FOR THE CONIES 183}

or three feet long, piled helter-skelter without form or order, but with such perfect and confusing repetition of the pattern, that fixed attention at any one crack or slab seemed to set the whole slide in motion. It was like trying to fasten the eye at some fixed spot on the surface of waving water. Add to this the absolute color-harmony of the rocks and the cony, together with the creature's polyphonous cry, and you have a case of well-nigh perfect protection. On his slide, even when in motion, he must be almost invisible to the sharpest-eyed eagle.

If you will think of a half-grown rabbit, the cottontail, only without a cotton tail, turned into a guinea-pig with large, round ears, you will get a pretty fair notion of the size, color, and shape of the cony, perhaps better called "pika," or "whistling hare," or " little chief hare." His legs are all of a length, so that he runs and walks instead of hops; and the soles of his feet are bare. He gets his name "cony" from the cony of the Bible (a very different animal) because, like the Old World cony, he lives among the rocks. The little cony of the Bible is Hyrax, who belongs to the elephant family, a curious remnant of an older 


\section{I84 WHERE ROLLS THE OREGON}

time, whose very holding on to life among the rocks speaks well for the protection they offer, scanty as may be the picking about their barren edges.

All the while the tremulous call kept coming from the slide. It was not the cry of several voices, not a colony whistling, as at first I thought, for, however gregarious they may be in a more favorable environment, here I am sure there were very few pairs, if not, indeed, a single pair only. There was but one small haycock curing in the stones, and not enough uncut grass in the neighborhood to feed more than a pair of conies for a winter, or so it seemed to me.

As I watched the slide, I finally made out the little whistler, and, with eyes sharpened to their work, was now able to follow him from rock to rock as he moved restlessly about. He called constantly, and as constantly stopped to listen. Plainly it was an answer that he expected. He was calling for some one, and the echo of his own voice disturbed him.

Now he would stop short on a slab and whistle, would lift his head to listen, and, hearing nothing, would dive into some long passage under the 
THE ROCKS FOR THE CONIES 185

rocks to reappear several feet or several yards away. Here he would pause again to listen, then to call, waiting a moment for the answer, before darting into the crack for another search through the tunnels.

Under and over the stones, up and down the slide, now close to me, now on the extreme opposite edge of the pile, he traveled, nervously, anxiously looking for something - for some one, I truly think; and my heart smote me when I thought that it might be for the dead mate whose little bare foot-pad had left the bloody print upon the rocks.

Up and down, in and out, he ran, calling, calling, but getting no answer back. This was the only cony that showed itself, the only live one I have ever seen; but I followed this one with my eye and with the field-glasses as it went searching and crying over the steep rock-slide until long past noon - with the whole camp down the cañon looking for me.

They might have known where to look: out of the cañon, back to the roof of the world, to the cony slide - if they could not wait for me.

Higher up than the mountain sheep or the 


\section{I86 WHERE ROLLS THE OREGON}

goat can live, where only the burrowing pocket gopher and rare field mice are ever found, dwells the cony. This particular slide was on one of the minor peaks, loftier ones towering all about. Just how much above sea-level this one was, I do not know, but far up in the arctic-alpine cold in a world of perpetual snow. The conies of Colorado live from ten to fourteen thousand feet above the sea.

By perpetual snow, I mean that the snow-banks never melt in the shadowed ravines and on the bare north slopes of the peaks. Here, where I was watching, the rock-slide lay open to the sun, the scanty grass was green beyond the gully, and the squat alpine flowers were in bloom, the saxifrage and a solitary aster - April and September together - blossoming in the edges of the snow just as fast as the melting banks allowed them to lift their heads. But any day the wind might come down from the north, keen and thick and white about the summits, and leave the flowers and the cony slide covered deep beneath a drift.

Spring, summer, and autumn are all one season, all crowded together - a kind of seasonal peak piercing for a few short weeks the long, 


\section{THE ROCKS FOR THE CONIES I 87}

bleak, unbroken land of winter here above the world.

But during this brief period the grass grows, and the conies cut and cure it, enough of it to last them from the falling of the September snows until the drifts are once more melted and their rock-slide warms in another summer's sun. For the conies do not hibernate. They stay awake down in their catacombs; buried alive in pitchblack night with snow twenty-five feet deep above them for nine out of twelve months of the year! Here they are away up on the sides of the wildest summits, living their lives, keeping their houses, rearing their children, visiting back and forth through their subways for all their long winter night, protected by the drifts which lie so deep that they keep out the cold.

Right near me was one of their little haycocks, nearly cured and ready for storing in their barns beneath the rocks; but this would not last long. It was already early August and what haying they had to do must be done quickly or winter would catch them hungry.

They cut and cock the grass about the slide until it is cured; then they carry it all below 


\section{$\simeq 88$ WHERE ROLLS THE OREGON}

against the coming of the cold. Naturalists who have observed them describe with what hurry and excitement the colony falls to taking in the hay when bad weather threatens to spoil it.

Hardy little farmers! Feeble little folk, why do you climb for a home with your tiny, bare-soled feet up, up, even above the eyrie of the eagle? Why, bold little people, why not descend to the warm valleys where winter comes indeed, but does not stay? Or farther down, where the grass is green the year around, with never a need to cut and cure a winter's fodder?

I do not know why - nor why upon the tossing waves the little petrel makes her bed; nor why, beneath the waves, "down to the dark, the utter dark," on "the great gray level plains of ooze" the "blind white sea snakes" make their homes, nor why at the north, in the fearful, faroff, frozen north, the little lemmings dwell; nor why, nor why, -

But as I sat there above the clouds listening to the plaintive, trembling whistle of the little cony, and hoping his mate was not dead, and wondering why he stayed here in the barren peaks and how he fared in the long black winter, I 


\section{THE ROCKS FOR THE CONIES 189}

said over and over to myself the lines of Kipling -

"And God who clears the grounding berg

And steers the grinding floe,

He hears the cry of the little kit-fox

And the lemming on the snow." 



\section{IX}

\section{MOTHER CAREY'S CHICKENS}





\section{IX}

\section{MOTHER CAREY'S CHICKENS}

“ Up and down! Up and down!

From the base of the wave to the billow's crown, And midst the flashing and feathery foam, The stormy petrel finds a home."

(3) ing. I don't remember how many miles we had made, but we had climbed far up the hill of the sea toward the second night, when across our bows cut a little band of small, dark birds with white rumps, which, veering, glancing down the ragged waves, seemed to settle in the wake of the ship. No one need be told that they were petrels - Mother Carey's chickens; but what I could hardly believe was that they were birds with webbed feet, to be sure - but birds with wings, adrift here in the vast of the ocean, and with nests and mates waiting for them along some far-off rocky shore. They must have circled the ship, for soon again they came keeling across our 


\section{WHERE ROLLS THE OREGON}

bows into a curling wave-crest, and, riding down the trough, were on the wing and gone.

They went straight into the night and as if to meet the coming storm. For a keen wet wind was blowing. The decks were cleared and empty except for myself and the officer who leaned hard against the wind as he paced his watch. It was an inscrutable, fearful night into which I was faring. My feet were strange to the pitching deck; my spirit was not at home on the sea. But the birds - it was their path I was following - where in this wild night of waves and coming storm had they gone?

Down in the black water the porpoises were leaping. Off on the sea there was nothing, nothing but the closing circle of storm, and I was turning from the rail with a shiver, when, far out on the gray chop, I caught sight of the petrels, rising and falling with the heave and sag of the sea.

Did they sleep on the sea, I wonder? Not that night, perhaps, as this was the nesting-season, but here night and day they pass the larger part of their lives. All through that long night I dreamed of them rising and falling on the chop. 


\section{MOTHER CAREY'S CHICKENS 195}

And often since, when the wind has been high, when the woods have roared and heaved, and the house has rocked in the might of the gale, I have seen that little brood of Mother Carey's chickens swirl through the breaking crest of some ghost wave, ride past my ship asleep, and vanish in the dream.

It is awesome enough to hear the creak of frozen branches, and the hiss of driving snow and rushing winds past your chamber, when you think that out in it all are the winter birds sleeping. They have a hundred shelters, however, a hundred hidings from the force of the storm. But on the unsheltered ocean there are only the yawning troughs that dip for a moment from the lash of the winds, only the tossing tumult of the waves. Who could fail to ask, seeing this troop of birds far out on the ocean, Whence do they hail? And whither are they bound? Not much larger than swallows, they have dared all the great liner dares, and more. They have cleared from some shore, but the ocean is their home. They love the waves; they revel in the storm. If seen on the North Atlantic in the summer they may be our Leach's petrel that nests on the islands in 


\section{WHERE ROLLS THE OREGON}

the mouth of the Penobscot Bay and northward; or Wilson's petrel, a migrant from the south; or near the European coast, the little "stormy" petrel that breeds from the Shetland Islands to the Mediterranean.

There are certain birds that since my childhood have had a strong hold upon my imagination. One of these is the stormy petrel-all petrels being "stormy" to me. I cannot remember when his wide-flung flight did not seem to me the very soul of the ocean, nor when I did not wish to follow him over the waves to his rookery on the cliffs. Yet I was a man before I saw my first flock of the birds skimming the waves of the Atlantic - a man in years, but still a child haunted by the lines of some poem called "The Stormy Petrel" read, or read to me, from some old McGuffey Reader, I imagine, before I ever started to school. A bird in a poem is worth almost as much to a child as a bird in a bush; perhaps more. I have learned many facts in the fields, but how many of my feelings have come to me out of books! I felt my stormy petrel long before I knew him. He was a poem long before he was a bird, and the beat of his wings must ever be - 
“ Up and down! Up and down!

From the base of the wave to the billow's crown."

I have not only seen him now, I have also followed him to his sea-cliff and pulled him out of his tame little hole of a burrow. Here was his nest, where I might make mine. His nest, but this was not his home, for back come the lines-

" And midst the flashing and feathery foam,

The stormy petrel finds a home."

The poetry got in ahead of the ornithology. I am glad it did; for that is the happier order, I think; just as I am glad that we have our youth before our old age. One who is young first stands an excellent chance of never growing entirely old. And so with poems and facts. There are many kinds of petrels, I am reminded by my ornithologist critic. In deference to him I have changed "stormy" several times so as to conform to the facts - Kaeding's for instance, is the petrel on Three-Arch Rocks in the Pacific, the stormy ("storm" alas! by the latest A.O.U. Check-List) petrel being an Atlantic bird nesting on the European side and only a rare wanderer to our shores. "Kaeding's" is the petrel of this chapter; accord- 


\section{WHERE ROLLS THE OREGON}

ing to the book; it may be, but not according to the poem, and when I read this chapter I shall read "stormy," whatever the unimaginative type says.

In an earlier chapter I have given a general description of Three-Arch Rocks Reservation and its multitudes of wild sea-life, a description that falls hopelessly short of the scene. I had looked at pictures of the Rocks, had listened to stories of their rookeries, but the only account that had greatly interested me was of the small colony of petrels nesting on the steep north slope of the summit of Shag Rock, the outermost of the three. It was the petrels above all else that I desired to see; it was this patch of marl or earthy guano on the top of the rock that I wished to climb to; for this little patch of earth was something that I could share with the birds, a point upon which we could meet, a place that their wave-wandering wings and my clod-heavy feet could have in common. The thought of it greatly moved me.

I must be somewhat of a mariner. My forbears, back for three hundred years, have all been doctors, farmers, and the like; and Quakers of Lon- 


\section{MOTHER CAREY'S CHICKENS 199}

don before that. But the sea is in me, though I go back beyond the Vikings for it. And there is something of the stormy petrel in us all, I think, for who can meet the little mariner on the waves and not follow him up and down, up and down, till the wonderful wings bring him to Shag Rock?

Shag is an immense pile; not a pile of rocks, but a single rude block of weathered basalt, longer than a city "block" and more than three hundred feet high. Wherever birds can find a foothold, and shelf enough for an egg, there they breed, a single pair, a rookery of thousands. The petrels nested on the top, coming and going only in the dark; and a night on the summit to see them come in to their burrows was to crown our trip to the Reservation.

Just to sleep in such a bed would be enough. To wrap one's self in one's blanket as the sun sinks behind the round of the Pacific, to see the night settle down upon the Rocks, to feel the large sea-wind sweep over the summit, to hear the swash on the ledges, the boom in the hollow caverns far below, and, close to one's head, the strange, wild clangor of the sea-birds - it would 


\section{WHERE ROLLS THE OREGON}

be enough to turn one's face to the mist in such a spot, and to know that one was part of this primordial life, cast up here, as the first life of the land had been cast, by the lift of the sea!

But how much more to lie here listening for the chitter of a small voice and for the fanning of small wings that know no dread, that have spanned the sweep of oceans, and outridden the wildest gales! I wanted to witness their coming home, to see, if possible, in the thick twilight of the summit, their shadows hovering over the slope, to hear their chittering at the mouth of the burrows, telling their mates that they had returned from their day and night upon the sea.

This petrel of Three-Arch Rocks digs its nesting-burrow in the earth and lays one egg. The burrow might hold both birds together, but only one bird is ever found in the nest-hole. While one is brooding, the other is off on its tireless wings - away off in the wake of your steamer, miles and miles from shore. All night it has been a-wing, and all day, but, as darkness begins to fall again, it remembers its mate and its nest on the rocks and speeds with the wing of the twilight to its own, to take its place in the little 


\section{MOTHER CAREY'S CHICKENS 201}

black burrow, while the mate comes forth and spreads her wings out over the darkening waters, not to return, it may be, until the day and the night have passed and dusk comes creeping once more over the sea.

But why waste words to make those who cannot understand know why we were willing to risk limb and life on the Rocks, not to mention the crossing of Tillamook Bar, in order to watch the coming and going of birds no larger than my hand? To them I speak in parables. And to you with hearts that understand I need not speak at all, for you know why we took the tug at Tillamook, why we fought for hours the three great breakers on the narrow, dangerous bar, why we steamed miles down the coast to the big rocks, where we landed amid the din of screaming gulls and bellowing sea-lions - why, in short, we never dreamed of counting the cost of watching for the petrels to come home on Shag Rock.

It is cheapest and safest, and, perhaps sanest, not to have any loves or enthusiasms. But it is also very stupid. A person so lacking might cross the ocean a hundred times and never see a stormy petrel. More than that, such a person 


\section{WHERE ROLLS THE OREGON}

might be too dull and mean and afraid ever to cross the ocean at all.

After steaming in around Shag Rock we landed from a yawl on a half-submerged ledge, driving off a bull sea-lion, an immense, disgruntled old fellow, who evidently could not live with the herd and his wretched temper, so had come out here where he could have his fill of soured silence and enjoy the solitary friendship of his precious ugly soul.

The rise and fall of the waves about the rocks was fully six feet, so we backed the yawl up as close as we dared, a man steadying it at the oars, another standing ready in the stern to leap when the sea should bring him up level with the ledge. Having landed him, we tossed him our cameras, provisions, a piece on every high wave, and even my eleven-year-old son, who scaled the rocks with us.

Everything safely cached, we drew the yawl upon the shelf of rock, ordered the tug to lie off and anchor, then got ourselves in shape for the climb.

It was now nearly noon. Since early morning an ugly fog had hung about us, but we had barely 
MOTHER CAREY'S CHICKENS 203

landed when the sun shot through the banks, promising us bright weather for our cameras, dry, safe footing on the cliffs, and a good night for watching on the peak.

It was hard to keep our heads on the way up with the birds driving at us, as it was hard to keep our feet on the rotten crumbling shelves and jutting corners that offered us their treacherous support. But my head was kept busy and out of mischief for most of the time with anxiety for my son, who showed no anxiety or ordinary human responsibility at all. We were mounting by ledge stages, each ledge the home of a colony of birds, and so thick with exciting eggs and young that the eleven-year-old boy was being forced to let go of one or was being held back from the other all the way. He climbed as if he had been hatched on the peak of Shag Rock. The rope about him was not necessary. Height and depth and the awful space about us held no terrors for him - such stuff is a live boy made of!

But all these things had terror enough for me, and I was glad to get over the rim, in reach of the top, although that gladness was troubled with 
the thought of how I was to get down. I had been brought up in the flat and gentle fields of New Jersey. I had climbed sand-dunes along the Jersey coast, and fences and trees, but never slippery, slimy bird rocks like these here in the Pacific.

Nothing I had ever seen on my native coast equaled this for wildness and strangeness and abundance of life. The very sea seemed vaster, no doubt because of the height of the rock, the mountains shoreward, and the bewildering, almost threatening, tumult of the alarmed birds spreading far out over the water.

While the cameras were being unslung and the moving-picture machine set up, I went after the petrels' nests. It was now about three o'clock; the sun was hot and the young birds, especially the young cormorants, suffered from their exposure when our presence frightened their parents off the nests.

Never, from the time a cormorant egg is laid till the young fly from the nest, are the sheltering wings of the parents taken from them for fear of the greedy gulls. Our appearance had upset the even balance of things and was causing great 
MOTHER CAREY'S CHICKENS 205

disturbance and loss of life, though we moved without so much as breaking an egg.

Just below the rocky backbone of the top lay the green sloping deck or roof in which burrowed the puffins and the petrels. While digging out a snapping, fighting old puffin, who left the lasting mark of her powerful bill on the game warden's hand, I came upon a small side hall or gallery running at right angles to the gallery of the puffin's and starting just within her front door. At the bottom of this I found my first petrel and drew her out with her one round white egg, which was about the size of a turtle-dove's.

She lays only one egg, and rears only one young at a time. So it is with the puffin, and the murre; but just why, with food so abundant, I cannot tell. She tried to escape, but finding that impossible, she ejected from her beak, or nostrils rather, a very strong offensive oil, the most rancid oil I ever smelled. If her burrow were filled with this reeking, choking odor, I could imagine her perfectly safe from almost any attack.

I stroked her gently until she grew quiet. Then I stretched out her wonderful wings, placed her small webbed feet upon my hand, felt her beat- 


\section{WHERE ROLLS THE OREGON}

ing heart between my thumb and finger, looked into her mild eyes, and tried to think that at last I held captive, in my hand, one of Mother Carey's chickens, "little Peter," the walker of the waves, the rider of curling crests, the lover of stormy seas.

But I could not think it. This was not the stormy petrel. This was only a small bunch of throbbing feathers - the least of all the web-footed birds. For so much greater is the power of the bird, so much mightier its spirit than its heartbeat and spread of wing, and with so much more had my imagination endowed her than with mere feathers and webbed feet, that I had to open my hand and free her in order to know that $I$ had had her - the bird of evil omen to the sailor, harbinger of foul weather, spirit of the sea wind and the wave.

She darted from my hand with a quick zigzag motion, as if dazzled with the sunshine, dipped over the rim of the top and with a flap was gone.

There was not a ray of sunshine, as a matter of fact, when I turned from following the bird to look at the sky. The afternoon was still young, 
yet the sun had disappeared, and the air, so thick with wings, was thickening now with fog that again was rolling in from seaward, blotting out the skyline and shutting darkly down about the gray, wild rocks.

The men packed their cameras, and, slipping into their coats, crept to shelter behind the peak, for a wind had come up with the fog, a raw, raking wind that drove the gulls careening far to leeward of the summit and forced them close to the sea for a landing.

The captain had warned us that a storm from this quarter might continue for a week, and it did look as if the whole wide Pacific were bearing down upon us. The fog soon changed to a drizzle, and this in turn to a driving slant, that forced me to crawl from point to point about the peak.

It was not a pleasant prospect for the night. Besides, it would be quite impossible either to see or to hear the petrels' return in the pitch dark that was falling, and in the wind that was already drowning the lesser sounds - the screaming birds overhead, the wash of the waves, and the hollow boom of the caverns from below. No one could 


\section{WHERE ROLLS THE OREGON}

tell with what violence it might sweep this un. sheltered top of Shag Rock, to the peril even of our lives.

There was nothing to do but climb down. It would surely clear by tomorrow, and, consoling ourselves, and particularly the eleven-year-old boy, with this hope, we backed over the edge of the peak for the descent.

The rocks were wet by this time, and the footing treacherous. The birds, as we worked slowly along, seemed to fear us less than earlier in the day, flying closer to our heads, their harsh cries and flapping wings in the gathering dusk adding not a little to the strain of the work.

Yet worse than the birds over me, was the emptiness behind me, the void and space beneath, which plucked and pulled at me, and which I could not turn upon and face. I could only reach down into it with a foot, feel out through it for an edge, a point, a seam of firm rock, anything to touch and stay me on.

Over the hanging places I was lowered with a rope, and down to me, bumping serenely along, his free hand patting all the little murres by the way, came Eleven Years. He wished to stay on the 


\section{MOTHER CAREY'S CHICKENS 209}

summit because it was storming; and would n't they tie him so fast that while dangling from the face of the cliffs he could use botb hands freely to handle and examine eggs and young birds?

About forty feet from the water was a weathered niche partly roofed with rock, and with a floor large enough to give us a sleeping-place. Here we stopped to wait for the morning.

This was not the wild summit, nor were the rookeries of murres and the gulls whistling and quacking near us the stormy petrels we had hoped to see, but it was the wildest spot that I had ever tried to go to sleep in. For a time the lantern of the tug showed off on the sea, but this, too, was soon snuffed out by the fog, and we were alone in the midst of the waters with only the sea-lions and the sea-fowl and the pounding waves in the arches to lull us into slumber. But I could not sleep. I was afraid I might miss something of it all. For wings were heard passing in the darkness, and now and then a form was seen hurtling past. Might they not be petrels, I wondered. But they passed too swiftly through the shadows to be made out. I would wait for to-morrow.

I am still waiting. 


\section{WHERE ROLLS THE OREGON}

The next day brought more wet and wind and chill. There might be a week of it, our prophet had said; and there was a week of it, as it turned out. The captain steamed in that afternoon and took us off, amid the din of a million screaming, bellowing voices.

The next time I climb Shag Rock I shall go storm-proof; for I yet intend to hear the winnowing wings of Mother Carey's chickens as they come in from the sea to take their turn on the nest. 


\section{X}

THE WILD MOTHER 



\section{$\mathbf{X}$ \\ THE WILD MOTHER}

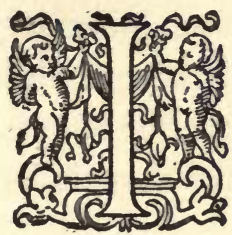

HEAR the bawling of my neighbor's cow. He calf was carried off yesterday, and since then, during the long night, and all day long, her insistent woe has made our hillside melancholy. But I shall not hear her to-night, not from this distance. She will lie down to-night with the others of the herd, and munch her cud. Yet, when the rattling stanchions grow quiet and sleep steals along the stalls, she will turn her ears at every small stirring; she will raise her head to listen and utter a low tender moo. Her full udder hurts; but her cud is sweet. She is only a cow.

Had she been a wild cow, or had she been out with her calf in a wild pasture, the mother in her had lived for six months. Here in the stable it will be forced to forget in a few hours, and by morning will have died.

There is a mother-principle alive in all nature 
214 WHERE ROLLS THE OREGON

which never dies. This is different from the mother-instinct, the mother-passion. The oak and the amœba respond to the mother-principle. It is a law of life; it is one of the constants of being. The mother-instinct or passion, on the other hand, occurs only among the higher animals; occurs not sporadically quite, for it is common enough; yet while generally found, and while one of the strongest, most interesting, most beautiful of animal traits, it is at the same time the most individual and the least constant.

This cow of my neighbor's that I hear lowing is an entirely gentle creature ordinarily, but with a calf at her side she will pitch at any one who approaches her. And there is no other cow of the herd that mourns so long when her calf is taken away. The mother in her is stronger, more enduring, than in any of the other nineteen in the barn. In my own cow it is hardly more than blind principle, hardly advanced beyond the oak tree's feeling for its acorns, or the amœba's for its divided self.

Out of the mother-principle there develops, far down the animal scale, the sexless, neuter, motherless mother, - the parent. It is out of this mere 
parent, as we ascend the scale, that we find the mother growing.

The female crab, attaching her eggs to her swimmerets, carries them about with her for their protection as the most devoted of mothers; yet she has no more concern for them, is no more conscious of them, feels no more for them, than the fruiting frond of a cinnamon fern feels for its spores. Here in the crab is the form, but not the substance, of the mother.

In the spider, however, just one remove up the scale from the crab, you find the mother-passion. Crossing a field the other day, I came upon a large female spider of the hunter family, carrying a round white sack of eggs, half the size of a cherry, attached to her spinnerets. Plucking a long stem of herd's-grass, I detached the sack of eggs without bruising it. Instantly the spider turned and sprang at the grass-stem, fighting and biting until she got to the sack, which she seized in her strong jaws and made off with as fast as her rapid legs would carry her.

I laid the stem across her back and again took the sack away. She came on for it again, fighting more fiercely than before. Once more she 


\section{WHERE ROLLS THE OREGON}

seized it; once more I forced it from her jaws, while she sprang and bit at the grass-stem to annihilate it. The fight must have been on for two minutes when, by a regrettable move on my part, one of her legs was injured. She did not falter in her fight. On she rushed for the sack as fast as I pulled it away. The mother in her was rampant. She would have fought for that sáck, I believe, until she had not one of her eight legs to stands on, had I been cruel enough to compel her. It did not come to this, for suddenly the sack burst, and out poured a myriad of tiny brown spiderlings. Before I could think, that mother had rushed among them and caused them to swarm upon her, covering her, many deep, even to the outer joints of her long legs, - so deep that I could not now have touched her with a needle except at the risk of crushing the young. I stood by and watched her slowly move off with her encrusting family to a place of safety.

I had seen these spiders try hard to escape with their egg-sacks before, but had never tested the strength of their purpose. I was interested to know how common this mother-instinct might be in them, and for a time made a point of tak- 
ing the sacks away from every one I found. Great differences appeared among them, the majority scurrying off with no other purpose than their own safety, one of them dropping the sack of its own accord, some of them showing a decided reluctance to leave it, a few of them a disposition to fight, but none of them the fierce consuming fire of the one that lost her leg.

It seems scarcely possible that in the same family and among the same species so great variation of instinct should exist; and no less remarkable that in so humble a form as the spider should be found, even occasionally, the fully developed mother, as against the mere parent, especially when among the fishes, higher forms and far removed from these invertebrate arachnids, we find the part of the mother (not the function of maternity) being largely assumed by the males.

It is the male stickleback that builds the nest; then goes out and drives the female in to lay her eggs; then straightway drives her out to prevent her eating them; then puts himself on guard to protect them from their other enemies, until the young shall hatch and be able to swim away by themselves. 


\section{WHERE ROLLS THE OREGON}

It is the male toadfish (Batracbus tau) that crawls into the nest-hole and takes charge of the numerous family. He may dig the hole, too, as the male stickleback builds the nest. I do not know as to that. But I do know that I once raised a stone in the edge of the tide along the shore of Naushon Island in Buzzards Bay, to find its under surface covered with round, drop-like, amber eggs, and, in the shallow cavity beneath, an old male toadfish, slimy and croaking, and with a countenance ugly enough to tie a prowling egg-eating eel into a hard knot. I have done this a score of times. The female deposits the eggs, glues them fast with much nicety to the under surface of the rock, as a female might, and finishes her work. Departing at once, she leaves the coming brood to the care of the male, who, from this time, without relief or even food in all probability, assumes the rôle and the responsibilities of mother.

Something like this is true of the common hornpout or catfish, I believe, though I have never seen it recorded, and lack the chance at present of proving my earlier observations. I think it is father catfish who takes charge of the 
brood, of the swarm, of kitten catfish, from the time the spawn is laid.

Instead of digging a hole under a stone after the fashion of the toadfish, or scooping out a shallow nest in the marginal sand of the pond, as does the sunfish, the "catty" or hornpout seeks out an abandoned muskrat burrow that runs into the bank from the edge of the water, and here deposits her eggs. As a boy I never questioned but that it was the mother fish on guard. I believe now, however, that it is the father fish in charge. I am hoping to get down to Lupton's Pond this spring to make sure of the matter; for all around the shores of that pond, in every muskrat hole and runway, I can scare out an old catfish by stamping hard on the tussocks or roots above the holes. Out he will come with a flop, and with a dart will make for the bottom of the pond; and out with him will spread the family of little catfish in a fine black cloud.

The old fish disappears almost at once, but in a moment you can see him coming back to the scattered family, to the little black things that look like small tadpoles, who soon cluster about him, as bees about their queen, and wiggle 


\section{WHERE ROLLS THE OREGON}

away with him into the deep dark waters of the pond.

We find the undeveloped mother in groups still higher up the scale - among the toads and reptiles, and even among the birds and mammals; but the higher we ascend the more pronounced and constant becomes the mother-passion in the female, and the more variable, weak, and intermittent its manifestation among the males.

A curious sharing of mother-qualities by male and female is shown in the Surinam toads of South America, where the male, taking the newly deposited eggs, places them with his own hands upon the back of the female. Here, glued fast by their adhesive jelly, they are soon surrounded by fresh-formed cells, each cell capped by a lid. In these cells the eggs hatch and the young go through their metamorphoses, apparently absorbing some nourishment through the skin of their mother, until they break through the lids of their cells finally and hop away. They might as well be toadstools on a dead stump, so far as motherly care or concern goes, for, aside from allowing the male to spread the eggs upon her back, she is no 
more a mother to them than the dead stump is to the toadstools. She is host only to the little parasites.

I do not know of a single mother among our reptiles, or a single father-mother. The motherpassion, so far as my observation goes, plays no part whatever in reptilian life. Whereas, passing on to the birds, the next order in the line, the mother-passion becomes, by all odds, the most interesting item, the most determining single factor in bird life. More than the song or the color or the courting of the male is the mother-love of the female in every ornithologist's records.

This is strikingly true also of the mammals. It is as if the watcher in the woods went out to see the mother animal only. It is her going and coming that he follows; her faring, foraging, and watch-care that let him deepest into the secrets of wild animal life.

On one of the large estates here in Hingham, a few weeks ago, a fox was found to be destroying poultry. The time of the raids, and their boldness, were proof enough that the fox must be a female with young. Poisoned meat was prepared for her, and at once the raids ceased. A few days 
later one of the workmen of the estate came upon the den of a fox, at the mouth of which lay dead a whole litter of young ones. They had been poisoned. The mother had not eaten the doctored food herself, but had carried it home to her family. They must have died in the burrow, for it was evident from the signs that she had dragged them out into the fresh air, to revive them, and deposited them gently on the sand by the hole. Then in her perplexity she had brought various tidbits of mouse and bird and rabbit and placed at their noses to tempt them to wake up out of their strange sleep and eat as hungry children ought to eat. Who knows how long she watched beside the still forms, and what her emotions were? She must have left the neighborhood soon after, however, for no one has seen her since about the estate.

I have elsewhere told of the cat, Calico, and her strange family; the thwarted cat mother making good the loss of her kittens by adopting a nest of young gray squirrels. A similar story comes to me from a reader in New York State. I will quote my correspondent's letter verbatim, not because there is an item in her account, re- 
markable as it is, that the most careful and experienced of observers would find hard to credit, but because it reads so much like a page out of the "Natural History of Selborne."

She writes:-

"Our Tootsy became a mother of several little kittens; as she was not in the best of health we thought best not to let her raise any of them. For a day or two she mourned for her little ones. As she was the pet of the family, we consoled her as best we could. This day I had her out on the lawn. I looked down to the bridge, saw a little squirrel up on one of the bridge-posts. I picked Tootsy up and let her climb the post and catch the squirrel, thinking it would take her mind off from her grief for a while.

"She brought it up on the lawn, and in place of playing with it and finally eating it, as is the nature of cats, she wanted to motber it. We then left her, and soon we discovered she had taken it upstairs in mother's bed and hid it. She staid with it all night, and we saw the little squirrel could take nourishment.

"The next day she found two more squirrels and brought them home, so we had a family of 


\section{WHERE ROLLS THE OREGON}

three. She brought them up until they were able to eat, meanwhile giving loads of pleasure; when they became so large and frisky we could do nothing with them, they would get into everything. We kept one, which disappeared shortly after. We think it had gotten with other squirrels, for sometimes when it did get out on the trees the cat would sit under the tree for hours at a time coaxing it back."

I have known a hen, too, deprived of her chickens, to adopt a litter of tiny kittens, brooding them and guarding them as her own.

The birds are structurally lower than the most primitive of the mammals; they are close kin to the cold-hearted reptiles, yet it is the bird, the motber bird, rather, that has touched our imaginations as perhaps the most nearly human of all wild things.

"O Ferusalem, Ferusalem, ... bow often would $I$ bave gatbered thy cbildren togetber, even as a ben gatberetb ber cbickens under ber wings, and ye would not!"

And an earlier Hebrew prophet, likening God's harsh providences to the rending of a lion, hastened on with the assurance that in his heart God 


\section{THE WILD MOTHER}

hovers over Jerusalem as little mother birds hover over their nests.

Hovering $\mathrm{He}$ will deliver it,

And passing back and forth

He will preserve it. ${ }^{x}$

The bird mother is the bravest, tenderest, most solicitous, most appealing thing one ever comes upon in the fields; the problem of her presence or absence, the degree or intensity of her being, and her behavior under stress, add more than anything else to the interest and charm of birdstudy. It is the rare exception, but we sometimes find the mother-instinct wholly lacking among the birds, as in the case of our notorious cowbird, who sneaks about, watching her chance when some smaller bird is gone, to drop her egg into its nest. The egg must be laid; the burden of the race has been put upon the cowbird, but not the precious burden of the child. Hers are only the functions of maternity. She is not a mother. She is body only, not a soul.

The same is true of the European cuckoo, but not quite true of our American cuckoos, in spite of popular belief. For our birds (both species) build rude, elementary nests as a rule, and brood

s Author's translation from the Hebrew, Isa., chap. xxxr. 


\section{WHERE ROLLS THE OREGON}

their eggs. Occasionally they may steal a robin's or a catbird's nest, may even destroy the owner's eggs (though never to my knowledge), in order to save labor - the unimaginative labor of laying one stick across another when one does not know how. But here is a plain case of knowledge waiting on desire. So undeveloped is the mother in the cuckoo that if you touch her eggs she will leave them - abandon her rude nest and eggs, as if any excuse were excuse enough for an escape from the cares of motherhood. How should a bird with so little mother-love ever learn to build a firm-walled, safe, and love-lined nest?

The great California condor, according to the records of the only one ever studied, is a most faithful and anxious mother, the dumb affection of both parents indeed, for their single offspring, being at times pathetically human. On the other hand, the mother in the turkey-buzzard is so evenly balanced against the vulture in her that I have known a brooding bird to be entirely undone by the sudden approach of a man and to rise from off her eggs and devour them instantly, greedily, and then make off on her serenely soaring wings into the clouds. 
Such bird mothers, however, are not the rule. The buzzard, the cuckoo, and the cowbird are striking exceptions. The flicker will keep on laying eggs as fast as you take them from the nest hole, until she has no more eggs to lay. The quail, like the cuckoo, will sometimes desert her nest if even an egg is so much as touched, but only because she knows that her nest has been discovered and must be started anew, in some more hidden place, for safety. She is a wise and devoted mother, keeping her brood with her as a "covey" all winter long.

Gilbert White tells the following story of the raven's mother-love :-

"In the center of this grove there stood an oak, which, though shapely and tall on the whole, bulged out into a large excrescence about the middle of the stem. On this a pair of ravens had fixed their residence for such a series of years that the oak was distinguished by the title of the Raven Tree. Many were the attempts of the neighboring youths to get at this eyry: the diffculty whetted their inclinations, and each was ambitious of surmounting the arduous task. But when they arrived at the swelling, it jutted out 


\section{WHERE ROLLS THE OREGON}

so in their way, and was so far beyond their grasp, that the most daring lads were awed, and acknowledged the undertaking to be too hazardous: so the ravens built on, nest upon nest, in perfect security, till the fatal day arrived in which the wood was to be leveled. It was in the month of February, when these birds usually sit. The saw was applied to the butt, the wedges were inserted into the opening, the woods echoed to the heavy blow of the beetle or mall or mallet, the tree nodded to its fall; but still the dam sat on. At last, when it gave way, the bird was flung from her nest, and, though her parental affection deserved a better fate, was whipped down by the twigs, which brought her dead to the ground."

One of the most interesting instances of variation of the mother-instinct in the same species of birds, which has ever come under my observation, occurred in the rookeries of the Three-Arch Rocks Reservation off the coast of Oregon.

We had gone out to the Reservation, as I said in the opening chapter, in order to study and photograph its wild life, and were making our slow way toward the top of the outer rock. Up the sheer south face of the cliff we had climbed, 
through rookery after rookery of nesting birds, until we reached the edge of the blade-like back, or top, that ran up to the peak. Scrambling over this edge, we found ourselves in the midst of a great colony of nesting murres - hundreds of them - covering the steep, rocky part of the top.

As our heads appeared above the rim, many of the colony took wing and whirred over us out to sea, but most of them sat close, each bird upon her egg or over her chick, loath to leave, and so expose to us her hidden treasure.

The top of the rock was somewhat cone-shaped, and in order to reach the peak, and the colonies on the west side, we had to make our way through this rookery of the murres. The first step among them, and the whole colony was gone, with a rush of wings and feet that sent several of the topshaped eggs rolling, and several of the young birds toppling, over the cliff to the pounding waves and the ledges far below.

We stopped instantly. We had not come to frighten and kill. Our climb up had been very disturbing to the birds, and had been attended with some loss of both eggs and young. This we 


\section{WHERE ROLLS THE OREGON}

could not help; and we had been too much concerned for our own lives really to notice what was happening. But here on the top, with the climb beneath us, the sight of a young murre going over the rim, clawing and clinging with beak and nails and unfledged wings, down from jutting point to shelf, to ledge, down, down the sight of it made one dizzy and sick.

We stopped, but the colony had bolted, leaving scores of eggs and scores of downy young squealing and running together for shelter, like so many beetles under a lifted board.

But the birds had not every one bolted, for here sat two of the colony among the broken rocks. These two had not been frightened off. That both of them were greatly alarmed, any one could see from their open beaks, their rolling eyes, their tense bodies on tiptoe for flight. Yet here they sat, their wings out like props, or more like gripping hands, as if they were trying to hold themselves down to the rocks against their wild desire to fly.

And so they were in truth, for under their extended wings I saw little black feet moving. Those two mother murres were not going to for- 
sake their babies - no, not even for fear of these approaching monsters, which had never been seen clambering over their rocks before!

One of the monsters stood stock still a moment for the other one, the photographer, to come up. Then both of them took a step nearer. It was very interesting. I had often come slowly up to quail on their nests, and to other birds. Once I crept upon a killdeer in a bare field until my fingers were almost touching her. She did not move because she thought I did not see her, it being her trick thus to hide within her own feathers, colored as they are to blend with the pebbly fields where she lays her eggs. So the brown quail also blends with its brown grass nest. But those murres, though colored in harmony with the rocks, were still, not because they hoped I did not see them. I did see them. They knew it. Every bird in the great colony had known it, and had gone - with the exception of these two.

What was different about these two? They had their young ones to protect. But so had every bird in the great colony its young one, or its egg, to protect; yet all the others had gone. Did these two have more love than the others, and with 


\section{WHERE ROLLS THE OREGON}

it, or because of it, more courage, more intelligence?

We took another step towards them, and one of the two birds sprang into the air, knocking her baby over and over with the stroke of her wing, coming within an inch of hurling it across the rim to be battered on the ledges below. The other bird raised her wings to follow, then clapped them back over her baby. Fear is the most contagious thing in the world; and that flap of fear by the other bird thrilled her too, but as she had withstood the stampede of the colony, so she caught herself again and held on.

She was now alone on the bare top of the rock, with ten thousand circling birds screaming to her in the air above, and with two men creeping up to her with a big black camera which clicked ominously. She let the multitude scream, and with threatening beak watched the two men come on. A motherless baby, spying her, ran down the rock squealing for his life. She spread her wing, put her bill behind him, and shoved him quickly in out of sight with her own baby. The man with the camera saw the act, for I heard his machine click, and I heard him say something under 
his breath that you would hardly expect a mere man and a game warden to say. But most men have a good deal of the mother in them; and the old bird had acted with such decision, such courage, such swift, compelling instinct, that any man, short of the wildest savage, would have felt his heart quicken at the sight.

Just how compelling might that mother-instinct be? I wondered. Just how much would that mother-love stand?

I had dropped to my knees, and on all fours had crept up within about three feet of the bird. She still had a chance for flight. Would she allow us to crawl any nearer? Slowly, very slowly, I stretched forward on my hands, like a measuring worm, until my body lay flat on the rocks, and my fingers were within three inches of her. But her wings were twitching; a wild light danced in her eyes; and her head turned itself toward the sea.

For a whole minute I did not stir. Then the wings again began to tighten about the babies; the wild light in the eyes died down; the long, sharp beak turned once more toward me. Then slowly, very slowly, I raised my hand, and gently 
234 WHERE ROLLS THE OREGON

touched her feathers with the tip of one fingerwith two fingers - with my whole hand, while the loud camera click-clacked, click-clacked hardly four feet away!

It was a thrilling moment. I was not killing anything. I had no high-powered rifle in my hands, coming up against the wind toward an unsuspecting creature hundreds of yards away. This was no wounded leopard charging me; no mother bear defending with her giant might a captured cub. It was only a mother bird, the size of a wild duck, with swift wings at her command, hiding under those wings her own and another's young, and her own boundless fear!

For the second time in my life I had taken captive with my bare hands a free wild bird. No, I had not taken her captive. She had made herself a captive; she had taken herself in the strong net of her mother-love.

And now her terror seemed quite gone. At the first touch of my hand she felt, I think, the love restraining it, and without fear or fret allowed me to push my hand under her and pull out the two downy babies. But she reached after them with her bill to tuck them back out of sight, and when 


\section{THE WILD MOTHER}

I did not let them go, she sidled toward me, quacking softly, - a language that I perfectly understood, and was quick to answer.

I gave them back, fuzzy, and black and white. She got them under her, stood up over them, pushed her wings down hard around them, her stout tail down hard behind them, and together with them pushed in an abandoned egg which was close at hand. Her own baby, some one else's baby, and some one else's forsaken egg! She could cover no more; she had not feathers enough. But she had heart enough; and into her mother's heart she had already tucked every motherless egg and nestling of the thousands of frightened birds that were screaming and wheeling in the air high over her head. 



\section{XI}

MOUNT HOOD FROM COUNCIL CREST 



\section{XI}

\section{MOUNT HOOD FROM COUNCIL CREST}

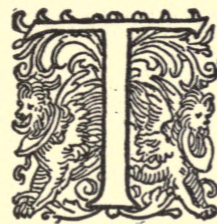

HERE is one glory of Rainier, and another glory of St. Helen's, and another glory of Mount Adams, for these majestic peaks differ from one another in glory, and they all differ in turn from Mount Hood, as Hood, in its difference only, exceeds them all in glory. For pure spirituality, for earth raised incorruptible and clothed upon with the holiness of beauty, Mount Hood, as seen in the heavens from the heights of Portland, is incomparable. Hood is not "The Mountain that was God," but as its snow-crowned summit, touched with the warmth of closing day, was first unveiled before me, my soul did magnify the Lord, for the vision, to my unaccustomed eyes, was all divine.

Portland is a city beautiful for situation; Oregon is a State of vast magnificence; and the glory of city and State is Mount Hood. There are loftier 


\section{WHERE ROLLS THE OREGON}

mountains - Rainier and Shasta are loftier; there are peaks that fill with awe and that strike with terror, while Hood only fills the soul with exultation, with the joy of beauty, of completeness, and perfection. Hood is but little over eleven thousand feet high, and easily climbed. Its greatness is not physical, not height nor power; but form rather, and spirit, and position. It stands sixty miles from Portland, dominating, but not overwhelming, the landscape, earth and all the sky a frame for it. From Council Crest the city seems a mere spectator looking off at the picture of a mountain rising in majestic symmetry, wrapped with a cold and indescribable purity, yet touched with an aspiration that were fervent were it less profound. Mount Hood from Portland is one of the perfect things of the world.

What will be the influence of this unearthly glory, I wonder, shining down forever upon the city? If there be any virtue, if there be any praise in thinking upon things that are true and pure and lovely, should not the presence of Hood, though acting slowly, act powerfully upon the spirit of the city? Shall Portland be the mother of one great poet, or of one great painter, or one 
great prophet because, high and lifted up above her streets, stands this holy mountain whose very shape is prophecy, whose radiance is the indwelling light of all true art, and the very soul of song?

Portland is a beautiful city, but born of the river. Young, strong, thriving, she is concerned with sawmills and salmon now, not with the tints on the snows of Hood, though they are often the color of salmon and of richer gold than the heart of pine. Young, eager, adventurous, she is bent on prosperity. Nor does prosperity wait to be won; it comes pouring in upon her,

From river and forest and orchard and ranch.

It is hard to think of Portland without feeling the singleness and intensity of her purpose to grow great and rich, as it is hard to write of her without changing from slow-footing prose to the gallop of verse. The cities along the Atlantic are full of rich men; but Portland is full of men growing rich. One can sit on Council Crest and see the process, as one can see nothing else, not even Hood, so often is the mountain shrouded in clouds and hid in the rain and mist. But where 


\section{WHERE ROLLS THE OREGON}

are Portland's poets, her painters and prophets? Asleep in the crater of Hood, I suppose, waiting for the mountain to give them birth.

Portland feels small need of poets now; they are not the stuff of pioneers! How many poets came over the Oregon trail? It seems incredible that the founders of this great city should still walk its streets, should gather in reunion to retell the story of those "early" days of the plains and the Indians, as I saw them gather. The very stumps would still be standing in the streets of Portland had they not been used for pavingblocks. Poets are poor hands at pulling stumps and paving streets. And what use has she for painters while her temple walls are rising? or for prophets when the salmon run their courses up the Columbia as the stars their courses in the skies?

None yet, but the time shall come. The people of Portland are proud of Hood; they are more concerned, however, with their corner lots. The marvel of Portland, according to those who have been there longest, is the rise in land values. There is not a lot in the city but has climbed far higher than the top of Hood. There is magic in Oregon land. The harder you hold it the higher 
it goes. I should say that the chief activity of the State is holding on to corner lots, a sort of husbandry singularly without virtue here in Massachusetts, but which in Oregon yields thirty, sixty, and a thousand fold. Towns are being laid out, roads built, farms cleared, orchards planted, and apples, the fairest apples in the world, are being picked, while the tent-pins of the population are still unpulled, the people of city and country guarding their land with guns, as it were, or watching their chance to jump some neighbor's claim. The most astonishing thing to me in all of Oregon was the price of land. But then, it is astonishing land. I stopped to watch the plowing of a great field of stubble in Joseph, where, as the plows were turning the black soil around the boundaries, the machines were threshing the yellow grain in the center. The crop had just been cut - sixty bushels to the acre, - the stubble being turned in for the next sowing, no manure, no dressing with it to feed the land. And this was the thirty-sixth consecutive year that wheat had been sown in this field, and that wheat had been threshed - sixty bushels to the acre - without a pound of fertilizer given back to the soil. 


\section{WHERE ROLLS THE OREGON}

It is not astonishing that in the middle of such fields the farmers of Oregon are pulling down their barns and building greater in their zeal to make Oregon the biggest-barned State of the Union. The heart of the Oregon farmer is in his barn; he has not even tried yet to build for his heart a house.

But this is still true of farmers East as well as West; of merchants East as well as West; as Portland is true of cities East and West. Portland is a typical American city, younger, that is all, and ravishingly fair. Daughter of the river on whose banks she stands, she is the destined bride of the mountain that watches yonder and waits. Hood is in no hurry.

I look down from Council Crest upon the growing city and see the present moment of my country hurried, crowded, headlong - a time of deeds and large and daring conquests, but without sign of "that over-faint quiet which should prepare the house for poets." Then I lift my eyes to Hood, serene and soaring in the far-off Heaven, and $l o !$ a vision of the future! not the Mountain that was God, but a summit that is song.

Drink, O City of Roses, of the pure cold waters 


\section{MOUNT HOOD}

from the snowy heights of Hood. Drink and thirst again. There are other springs in the summit than those which feed Bull Run - fountains higher up of living water such as flowed in Helicon. 



\section{INDEX}





\section{INDEX}

Aigrettes, 42, 43.

Aneroid Lake, 175.

Animals, wildness persistent in domesticated, 119-128; the play of, 159-168; mother-love in, 213-235.

Antelope, a mother and young, 86-9i.

Automobile, a desert, 49.

Avocet, 75 .

Badger, 54 .

Beard-tongue, 152, 179.

Bend, Ore., 45, 53.

Birds, of Three-Arch Rocks, 3-7, 9-1 I, 18-25, 197-210; protection of, 32-38, 42, 43; at Silver Lake, Ore., 74-77, 82; of Malheur Lake Reservation, 94II5; Oregon sanctuaries for, 97, 98; mother-love in, 109, I10, 221, 224-235.

Blitzen River, 108, 109, II3.

Blitzen River valley, 36.

Boar, wild, 126.

Bob-white, or quail, 227, 23 I.

Burns, Ore., 47, 48, 53, 6I-68.

Butterflies, on Mt. Hood, I 57-159, 162; angry, I6I; flocking, 162 . Buzzard, turkey, 226.

Catfish, 218, 219.

Cats, wildness, 124, 125 ; as fostermothers, 222-224.

Cattle, ancestry, 128; the herdspirit among, I28-r3I; a stampede, 131-143. See also Cow.
Chickens, play and fighting, 16 . Condor, California, 34, 35, 226.

Cony, 173-190.

Cormorant, Brandt's, 3, 4, 9, 10, 22, 204.

Council Crest, 239-241.

Cow, the, 126, 127; mother-love in, 213, 214. See also Cattle.

Cowbird, 225.

Coyotes, 56, 71-73, 75-85, 92; the coyote of Pelican Point, 82; bark, 83,84 ; team hunting, 86-91.

Crab, 215 .

Crow, 32, 33, 40, 161 .

Crow, Clarke's, 36, 37.

Cuckoos, 225, 226.

Danish heath, 12-14.

Deschutes Forest Reservation, 48.

Deschutes River, cañon of, 29$3 \mathrm{I}$.

Desert, an automobile ride over the, $47-60$; the wolf of the, $7 I^{-}$ 92.

Dogs, 125, 126; Pups's play, 165. 166.

Egret, American, 42, 71, 74, 80, 96; at Malheur Lake, 99-107. Elephant, 163.

Emerson, Ralph Waldo, quoted, 126.

Farms and farmers, Oregon, 243,

244. 
Fear, contagion of, 232.

Finley, William L., 7, 61, 63, 96, 97, 231-233; his story of the egrets, 99-105.

Fishes, at play, 167, 168; motherlove in, 217-219.

Flicker, 227.

Flowers, on Mt. Hood, 151-153; of the Wallowa Mountains, $179,186$.

Fox, red, 84 ; playing with a golfball, 166, 167; an instance of mother-love, 221, 222.

Foxhounds, 125 .

Glacier, on Mt. Hood, I54.

Goose, Canada, 77.

Grebe, eared, 107-114.

Guillemot, pigeon, 4, 21.

Gull, Western, 21, 24.

Gulls, 3, 4.

Hare, little chief, 173-190.

Heath hen, 34 .

Hen, adopting kittens, 224.

Heron, night, -77 .

Heron, white. See Egret.

Hibbard, Dr. L. E., his coyote and antelope story, 86-91.

Hippopotamus, 160.

Hogs, 126.

Hornpout, 218, 219.

Horse, Peroxide Jim, 134-143.

Hunter, the, cruelty of, 77,78 .

Hyrax, 183.

Imnaha River, 173, 174, 179. Infusorian, 163,164 .

Jay, Oregon, or whiskey-jack, 40, 41.

Joseph, Ore., 243.
Killdeer, 231.

Kipling, Rudyard, quoted, 189.

Lake Malheur Reservation. See Malheur Lake Reservation.

Land, in Oregon, 242-244.

Lupton's Pond, N.J., 219.

Malheur Lake, among the birds of, 95-II 5 .

Malheur Lake Reservation, 48, $63,97,98$.

Mallard, 77.

Mammals, mother-love in, 221224.

Minnows, 167, 168.

Mother Carey's Chickens, 193197. See also Petrel, Kaeding's. Mother-love, 109, 110, 213-235. Mt. Hood, 37; the ascent of, $147^{-}$ 159; storm on, 169, 170; and Portland, 239-245.

Muir, John, quoted, 36, 37 .

Mules, 175 .

Murre, California, 3, 4, 19-21, 24, 205, 229; a mother murre, 230235 .

Nighthawk, Western, 55.

Nutcracker, Clarke's, or Clarke's Crow, 36, 37.

Oregon, the land of, 242-244.

Otter, 164, 165.

Owl, burrowing, 55, 56 .

Paramocium caudatum, 163,164 . Pelican, white, 74, 80, 112.

Peroxide Jim, 134-143.

Petrel, Kaeding's, 25, 197-210.

Petrel, Leach's, 195.

Petrel, stormy, 196, 197. . 
Petrel, Wilson's, 196.

Petrels, 193-197.

Phala rope, Wilson's, 77.

Pheasant, China, 120, 121.

Picket-pin (ground squirrel), 55, 56,81 .

Pigeon, passenger, 96.

Pika, 173-190.

Play, in animals and in men, I59-168.

Plumage, importation of, 33,42 .

Plume-hunters, 99-107.

Portland, Ore., 239-245.

Primrose, American, 55.

Pronghorn. See Antelope.

Puffin, tufted, 205.

Pups, the dog, 165, 166.

Quail, 227, 23 I.

Rabbit, jack, 55, 72, 79, 8 r.

Rattlesnake, 75 .

Raven, 29-32, 34-36, 38-4I, 43;

Gilbert White's story, 227, 228.

Reservations, bird and game, 718.

Sage hen, 54, 55 .

Sagebrush, 47-60.

Scorpion, 56.

Sea-lions, 5, 6, 9-1 1, 24, 202.

Shag Rock, 5, 18-25, 198-210, 228-235.

Shrike, 55 .

Silences, 74, 75.

Silver Creek, 58.
Silver Lake, 71, 74-82, 92, 105.

Silvies River, 48, 62, 67, 100 .

Sparrow, sage, 54 .

Spiders, mother-love in, 215-217.

Squirrel, gray, I61, 222.

Squirrel, ground. See Picket-pin.

Squirrels, young, adopted by cats, 222-224.

Steins Mountains, 48.

Stickleback, 217.

Thrasher, sage, 54 .

Three-Arch Rocks, 3-25, 197210, 228-235.

Tillamook Bar, 3, 201.

Toad, Surinam, 220, 221.

Toadfish, 218.

Trout, 173.

Trout fry, 6r-67.

Tule Lake, 82.

Turkey, the, 121-124.

Turkey-buzzard, 226.

Vulture, turkey, 226.

Wade, the boss of the "buckaroos," 132-143.

Wallowa Lake, 176.

Wallowa Mountains, 40, 4I; finding the pika in, 173-190.

Weeks-McLean bill, 33 .

Whiskey-jack, 40, 41 .

White, Gilbert, quoted, 227, 228.

Wild, preservation of the, 7-18.

Wolf, timber, 84 .

Wolves, 7I-73. 





\title{
$\bar{M} 532970$
}

\author{
QH:1 \\ 5514 \\ Biol. \\ Lib.
}


- 1 - 